arquitetura de espaços livres interface entre projeto e conforto urbano

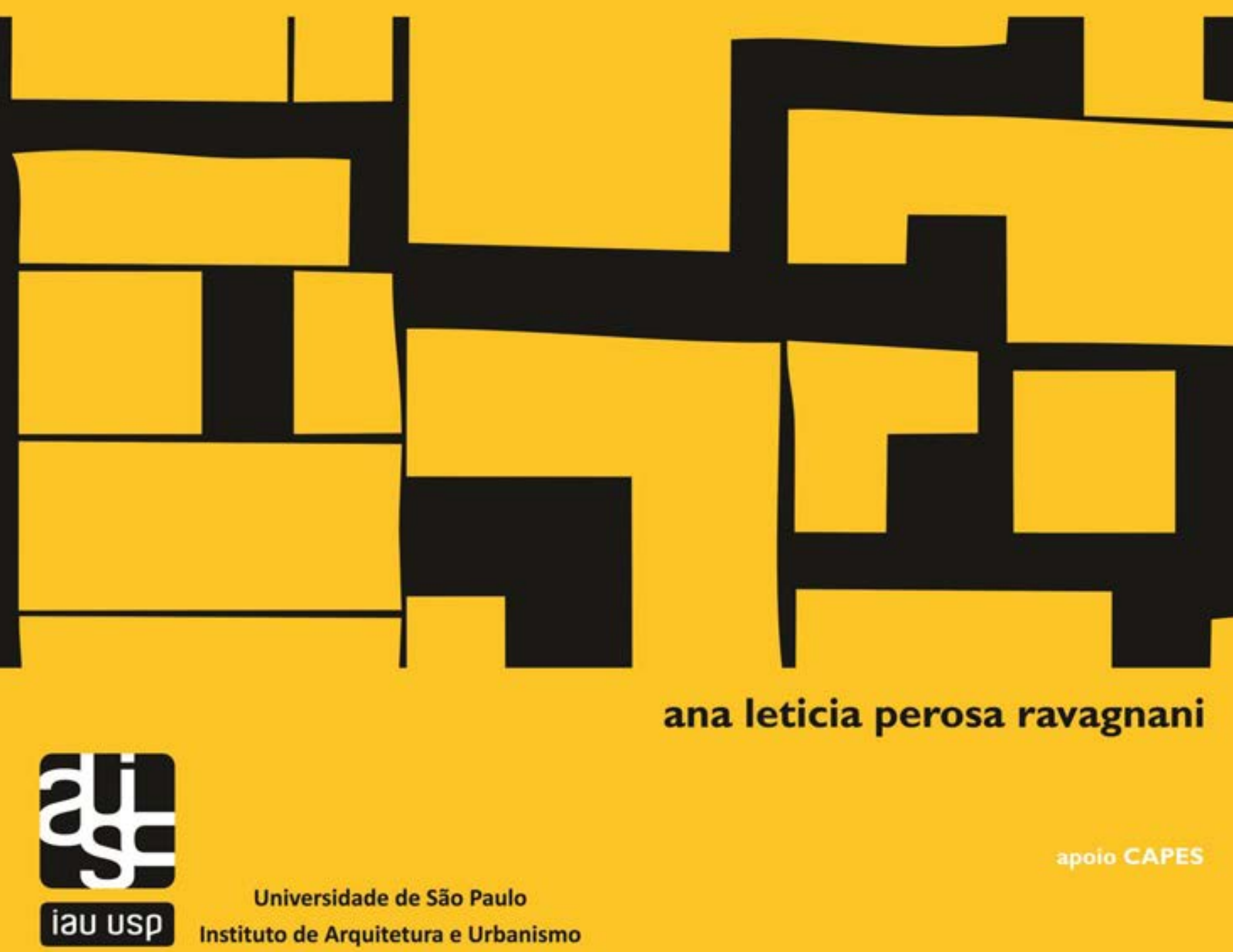



Dissertação apresentada ao Programa de PósGraduação do Instituto de Arquitetura e Urbanismo da Universidade de São Paulo, como parte dos requisitos para obtenção do título de Mestre em Arquitetura e Urbanismo.

Área de Concentração: Teoria e História da Arquitetura e do Urbanismo

\section{arquitetura de espaços livres: interface entre projeto e conforto urbano}

Ana Leticia Perosa Ravagnani

orientação

Prof. Assoc. Dr. Joubert José Lancha

coorientação

Prof ${ }^{a}$. Dr ${ }^{a}$. Karin Maria Soares Chvatal

apoio CAPES

SÃO CARLOS

2015 
AUTORIZO A REPRODUÇÃO TOTAL OU PARCIAL DESTE TRABALHO, POR QUALQUER MEIO CONVENCIONAL OU ELETRO̊NICO, PARA FINS DE ESTUDO E PESQUISA, DESDE QUE CITADA A FONTE.

Ravagnani, Ana Leticia Perosa

arquitetura de espaços livres: interface entre projeto e conforto urbano / Ana Leticia Perosa Ravagnani; orientador Joubert José Lancha; coorientador Karin Maria Soares Chvatal. São Carlos, 2015.

Dissertação (Mestrado) - Programa de Pós-Graduação em Arquitetura e Urbanismo e Área de Concentração em Teoria e História da Arquitetura e do Urbanismo -Instituto de Arquitetura e Urbanismo da Universidade de São Paulo, 2015.

1. espaços livres. 2. microclima. 3. projeto urbano. 4. conforto ambiental. 5. arquitetura da paisagem. I. Título. 


\section{FOLHA DE JULGAMENTO}

Candidata: Arquiteto Ana Leticia Perosa Ravagnani

Título da dissertação: "Arquitetura de Espaços Livres: interface entre projeto e conforto urbano".

Data da defesa: 08/06/2015

Comissão Julgadora:

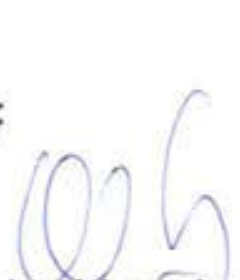

Prof. Assoc. Joubert José Lancha (orientador) (Instituto de Arquitetura e Urbanismo - /AU/USP)

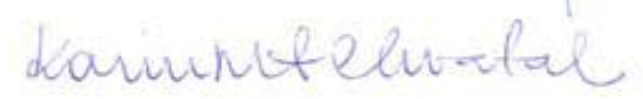

Profa. Dra. Karin Maria Soares Chvatal

APROVA DA

\section{Resultado:}

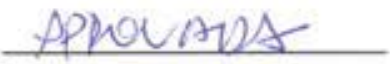

(Instituto de Arquitetura e Urbanismo - IAU/USP)

Profa. Dra. Paula da Cruz Landim y Goya

(Universidade Estadual Paulista Júlio de Mesquita Filho)

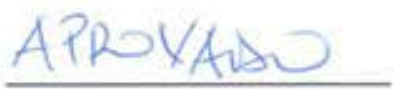

Presidente e Coordenador do Programa de Pós-Graduação em Arquitetura Urbanismo: Professor Associado Márcio Minto Fabrício 


\begin{abstract}
À minha família, origem dos meus valores; especialmente à memória do meu irmão Zé-Ito, um visionário e realizador de cidades para pessoas.
\end{abstract}





\section{AGRADECIMENTOS}

Aos meus filhos Gabriel e Beatriz, com quem compartilhei as dúvidas, angústias e momentos felizes deste trabalho, pela maturidade com que assumiram suas responsabilidades na minha ausência.

Ao Joubert, pela oportunidade e confiança no projeto, por sua integridade, pela sensibilidade na visão de conjunto e apoio na estruturação dos conteúdos centrais da pesquisa.

A Karin, pelo extremo cuidado no acompanhamento de cada etapa da coorientação e imprescindível suporte na fundamentação teórica, pesquisa de campo e exigências quanto à coerência do trabalho.

A Profa Dra Paula Landin, pela importante contribuição neste percurso acadêmico e participação na banca de qualificação.

Aos funcionários do IAU-USP, por todo auxílio prestado, especialmente ao Pedro Mattia, responsável pelo Laboratório de Conforto do IAU-USP, pelo apoio técnico na operação de coleta de dados microclimáticos, e, ao professor Victor Roriz, pelo fornecimento de arquivos de dados climáticos.

Aos alunos de arquitetura da Unirp Gladys Alana Leal, Mariana Lopes, Rebeca Molina, Thais Schiavini e à arquiteta Aline Covelo pela ajuda na coleta de dados e pesquisa de campo. E a arquiteta Thaisa Porfírio pelo trabalho de modelagem 3D. Aos amigos, especialmente Andréia Hipólito, Márcia Mikai, Paulo Bispo e Sidnei Spósito pelos inúmeros momentos em que pude contar com eles, das mais diferentes formas.

À Delcimar Teodósio, pela confiança, orientação e apoio integral a este projeto. À Maria Cristina Sanches, por um dia haver me convidado para dar aulas de projeto, origem de toda esta estória.

Ao Centro Universitário Rio Preto e às Faculdades Integradas Dom Pedro II, pela oportunidade de experiência na docência e todo apoio e incentivo para a conclusão deste trabalho.

A todos que direta ou indiretamente participaram e contribuíram para a conclusão desta etapa da vida profissional.

A Capes, pela bolsa de mestrado que permitiu a realização deste trabalho. 



\section{RESUMO}

\section{RAVAGNANI, A.L.P., arquitetura de espaços livres: interface entre projeto e conforto urbano.}

Este trabalho tem por objetivo gerar diretrizes de projeto para uma área localizada no centro da cidade de São Jose do Rio Preto, considerando a influência que as diferentes morfologias de espaços livres provocam no microclima. Para o estudo, foi adotado um conjunto de procedimentos metodológicos que possibilitou a caracterização e análise de três configurações urbanas distintas: as praças Rui Barbosa e Dom José Marcondes e um trecho do "calçadão" da Bernardino. Mesmo situados dentro de uma mesma área urbana, com características ambientais semelhantes, os três pontos apresentam configurações e geometrias distintas. A análise do entorno construído por meio de mapas de gabarito de altura, vegetação, materiais de recobrimento da superfície do solo mostrou particularidades que interferem no microclima e influenciam o uso do espaço. A coleta de dados microclimáticos contribuiu para confirmar a hipótese de que, em um mesmo ambiente climático, as variações da morfologia urbana modificam as condições de conforto e interferem na qualidade e uso dos espaços livres. As conclusões destes estudos resultaram em recomendações para o projeto, demonstrando de que forma a análise microclimática pode se transformar em importante ferramenta no processo de projeto de arquitetura de espaços livres, orientando decisões favoráveis às condições ambientais e uso humano.

Palavras-chave: espaços livres; microclima, projeto urbano, conforto ambiental, arquitetura da paisagem. 



\section{ABSTRACT}

\section{RAVAGNANI, A.L.P., architecture of open spaces: the interface between design and urban comfort.}

This work aims to generate design guidelines for an area located in the center of the city of Sao Jose do Rio Preto, considering the influence that the different morphologies of open spaces cause the microclimate. For the study, it adopted a set of methodological procedures that enabled the characterization and analysis of three distinct urban settings: the squares and Rui Barbosa Dom José Marcondes and an excerpt from "promenade" of Bernardino. Even situated within the same urban area, with similar environmental characteristics, the three points have different configurations and geometries. The analysis of the built environment through tall template maps, vegetation, soil surface coating materials showed characteristics that affect the microclimate and influence the use of space. The gathering of microclimate data helped to confirm the hypothesis that, in the same climatic environment, changes in urban morphology modify the conditions of comfort and interfere with the quality and use of open spaces. The findings of these studies resulted in recommendations for the project, demonstrating how the microclimate analysis can become an important tool in the process of open space architecture design, guiding decisions favorable to environmental conditions and human use.

Keywords: open spaces; microclimate, urban design, environmental comfort, landscape architecture. 



\section{SUMÁRIO}

INTRODUÇÃO

I ARQUITETURA DE ESPAÇOS LIVRES:

INTERFACE ENTRE PROJETO E CONFORTO URBANO

I.I Espaços livres: definições e relação com a cidade 27

I.2 Morfologia urbana 31

I.3 Arquitetura de espaços livres 34

I.3.I Bioclimatismo 36

I.4 Microclima urbano e conforto em espaços livres 37

I.4.I Estudos aplicados de microclima urbano 37

1.4.2 Arquitetura de espaços livres e sua influência na qualidade térmica urbana 39

I.5 Princípios de desenho urbano 42

1.5.I Princípios para as regiões tropicais de clima quente- seco 43

1.5.2 Princípios para as regiões tropicais de clima quente-úmido 43

1.5.3 Princípios para as regiões tropicais de clima tropical de altitude

I.6 A vegetação urbana

I.6.1 Vegetação e vento 48

2 OBJETO DE ESTUDO 49

2.I Metodologia 49

2.I.I Método proposto por Katzchner (1997) 49

2.I.2 Análise bioclimática de espaços livres 53

2.2 Caracterização do objeto de estudo 58

2.2.1 São José do Rio Preto: aspectos físico-territoriais 59

2.2.2 Aspectos históricos e urbanísticos 65

2.2.3 Áreas verdes e espaços públicos na cidade $\quad 79$

2.2.4 Delimitação da área objeto de estudo 83

2.3 Planejamento da pesquisa de campo 85

2.3.I Instrumentos de medição $\quad 86$ 
3 CARACTERIZAÇÃO DO OBJETO DE ESTUDO E PESQUISA DE CAMPO

3.I Caracterização morfológica 93

3.2 Análises 102

3.2.1 Morfologia dos pontos de medição 103

3.2.2 Caracterização do microclima nos pontos de medição III

3.2.3 Perfil e comportamento do usuário 118

3.2.4 Análise do resultado das entrevistas e discussões I2I

3.2.5 Conclusão das análises 129

4 DIRETRIZES, PROPOSTA DE INTERVENÇÃO E CONCLUSÕES 133

4.I Diretrizes bioclimáticas 133

4.2 Análise das sombras $\quad 135$

4.3 Etapas de projeto 138

4.4 Diretrizes de projeto 139

4.4.I Estratégias para melhoria do microclima 139

4.4.2 Estratégias para adequação dos espaços livres ao uso e escala humana 140

4.4.3 Aplicação de princípios bioclimáticos ao desenho urbano de área no Centro de São José do Rio Preto |4|

4.5 Proposta de intervençao bioclimática 144

4.6 Conclusões 150

4.6.1 Trabalhos futuros |5]

REFERÊNCIAS $\quad 152$

$\begin{array}{lr}\text { ANEXOS } & 159\end{array}$ 


\section{LISTA DE FIGURAS}

Figura I Entendimento de Ashihara (1982) sobre espaço exterior como espaço criado para delimitar a natureza.

Figura 2 Efeito de agrupamentos arbóreos na temperatura do ar nos períodos diurno e noturno.

Figura 3 Efeitos da vegetação na modificação da direção e velocidade dos ventos. Fonte: Mascaró, 1996.

Figura 4 - Principais espaços livres na área central de São José do Rio Preto

Figura 5 - Gráfico com a média mensal mínima e máxima de temperatura de bulbo seco e umidade relativa do ar. Fonte: arquivos climáticos gerados pela estação climatológica de José Bonifácio-SP LABEEE-UFSC

Figura 6 - Temperatura de bulbo seco plotada na carta solar no período de dezembro a junho - José Bonifácio. Fonte: arquivos climáticos gerados pela estação climatológica de José Bonifácio-SP; LABEEE-UFSC

Figura 7 - - Temperatura de bulbo seco plotada na carta solar no período de junho a dezembro - José Bonifácio. Fonte: arquivos climáticos gerados pela estação climatológica de José Bonifácio-SP; LABEEE-UFSC

Figura 8 - Rosa dos Ventos para José Bonifácio Fonte: arquivos climáticos gerados pela estação climatológica de José Bonifácio-SP; LABEEE-UFSC 64

Figura 9 - Carta bioclimática para José Bonifácio. Fonte: arquivos climáticos gerados pela estação climatológica de José Bonifácio-SP; LABEEE-UFSC 65

Figura 10 Primeiro mapa do Patrimônio de São José elaborado por Ugolini em 1893 e indicação do núcleo urbano central e principais rios e córregos que delimitam a área. No detalhe ampliado, a indicação de área reservada às praças centrais. Fonte: BRANDI, 2002.

Figura II Esquina da Rua Siqueira Campos com Bernardino de Campos na década de 20. Fonte: Arquivo Público Municipal e Figura 12- Praça Rui Barbosa, 1918 
Figura 13 Detalhe de traçado avançado de Ugolini com indicação da área reservada às praças e subdivisão dos primeiros lotes urbanos.

Figura 14 Antiga Catedral, vista a partir da Praça Dom José Marcondes, 1956

Figura 15 Praça Rui Barbosa na década de 50

Figura 16 - Foto aérea do centro em que se identifica a distância menor entre as ruas Voluntárias de São Paulo e Bernardino de Campos, onde Luis Saia imaginou haver sido planejada uma avenida central.

Figura 17 - Edifícios construídos com recuo de três metros e ampliação das calçadas conforme proposta de Luís Saia.

Figura 18 Edifício construído baseado nos preceitos do Plano Saia, em que o recuo do piso térreo favorece o passeio público com a ampliação do espaço livre, a calçada. Na foto observa-se o fechamento deste recuo com gradil, intervenção posterior.

Figura 19 - Recorte do mapa da Lei de zoneamento mostrando a classificação da zona comercial (quadras em cinza escuro). 'Fonte: TEODÓZIO, 2008

Figura 20 - Calçadão na rua Bernardino de Campos, Foto Débora Zórnio 75

Figura 21 - Mapa com indicação de área pedestrianizada 75

Figura 22 Praças Dom José Marcondes, Igreja de São Losé e Praça Rui Barbosa ao fundo, década de 50

Figura $23 \bigcirc$ mesmo local na década de 90 , com sua configuração atual. 76 Figura 24 - Recorte da área central no mapa de parcelamento, uso e ocupação do solo, parte da Lei de Zoneamento N 5 I35 de 1992.

Figura 25 Recorte da área central no mapa do Plano Diretor de Desenvolvimento Sustentável de 2006 e indicação de Áreas de Especial Interesse (AEI). 
Figura 26 Praça Dom José Marcondes, projeto de 1993 do arquiteto Milton Faria Assis Junior em registro do Quapá realizado em 1999. Fonte: Quapá - Banco de Dados

Figura 27 Calçadão da Tiradentes, projeto realizado em 198I pelo arquiteto Francisco Carlos Verroni. Fonte: Quapá - Banco de Dados. 81

Figura 28 Parque Setorial Lagos I e 2, projeto dos arquitetos Jamil Kfouri e Mirthes Baffi. Fonte: Quapá - Banco de dados.

Figura 29 Localização, delimitação e informação de vias do objeto de estudo. Fonte Google Earth.

Figura 30 - Mapa de localização dos pontos amostrais e entorno imediato com gabarito edificado

Figura 3I - Mapa de topografia, elaborado a partir de mapa cadastral da Prefeitura Municipal e análise in loco - novembro/20I2

Figura 32 - Mapa de uso e ocupação do solo, elaborado a partir de mapa cadastral da Prefeitura Municipal e análise in loco - novembro/2012

Figura 33- Mapa de altura das edificações, elaborado a partir de mapa cadastral da Prefeitura Municipal e análise in loco - novembro/2012

Figura 34 - Gabarito de figura/fundo, elaborado a partir de mapa cadastral da Prefeitura Municipal e análise in loco - novembro/2012

Figura 35 - Gabarito de espaços livres de edificação, elaborado a partir de mapa cadastral da Prefeitura Municipal e análise in loco - novembro/2012 99

Figura 36 - Mapa de Vegetação, elaborado a partir de mapa cadastral da Prefeitura Municipal e análise in loco - novembro/2012

Figura 37 - Mapa de recobrimento do solo, elaborado a partir de mapa cadastral da Prefeitura Municipal e análise in loco - novembro/2012

Figura 38 - Gráfico do comportamento da temperatura do ar $\left({ }^{\circ} \mathrm{C}\right)$ média nos pontos de medição e na estação automática Cetesb, em todos os dias e horários de medição. 
Figura 39 Gráfico do comportamento da umidade do ar (\%) nos pontos de medição e na estação automática Cetesb, em todos os dias e horários de medição.

Figura 40 Temperatura e umidade do ar nos pontos amostrais aferidos no dia I (I7/03/13)

Figura 4I Temperatura e umidade do ar nos pontos amostrais aferidos no dia $2(18 / 03 / 13)$

Figura 42 Gráfico do comportamento da velocidade do vento nos pontos de medição e na estação automática da Cetesb, em todos os dias e horários de medição.

Figura 43 - Gráfico de temperatura do ar (medição manual) nos pontos de medição em todos os dias e horários de medição.

Figura 44 - Temperatura média de recobrimento do solo nos três pontos, concreto ao sol e à sombra

Figura 45 - Temperatura de materiais de superfície de recobrimento do solo nos três pontos, em todos os dias e horários de medições.

Figura 46 - Gráfico do comportamento da temperatura superficial de materiais com temperaturas extremas (asfalto - máxima / solo nu mínima), aferido em todos os dias e horários de medição.

Figura 47 - Temperatura média de superfície e temperatura do ar por ponto de medição aferidas em todos os dias e horários.

Figura 48: Distribuição de entrevistados por faixa etária em número absoluto

Figura 49: Número absoluto de entrevistados por gênero

Figura 50 - Número de entrevistados por raça

Figura 5 I - Condição física dos entrevistados em número absoluto

Figura 52 - Gráfico da atividade realizada pelo entrevistado no momento da entrevista

Figura 53 - Distribuição dos entrevistados sob a condição de sombra ou sol no momento da entrevista 
Figura 54 - Análise se entrevistados estavam no sol 5 minutos antes da entrevista

Figura 55 - Análise da frequência ao local em números relativos

Figura 56 - Sensação térmica média em todos os horários e pontos no dia $17 / 03 / 2013$

Figura 57 - Sensação térmica média em todos os horários e pontos no dia $18 / 03 / 2013$

Figura 58 - Sensação térmica média em todos os horários, dias e pontos de medição.

Figura 59 - Preferência térmica em todos os pontos e horários de medição no dia $17 / 03 / 2013$

Figura 60 - Análise da percepção da luminosidade em todos os dias e horários de medição

Figura 6I - Análise do principal elemento percebido pelo entrevistado I28

Figura 62 Mapa indicando áreas de sombra e sol em 21/12, às $17 \mathrm{hs} 00$

Figura 63 - Mapa indicando áreas de sombra e sol em 21/06 às I7hs00 137

Figura 64 proposta de readequação bioclimática das praças Rui Barbosa e Dom José Marcondes e “calçadão” da Bernardino - implantação

Figura 65 Vista aérea a partir do início da rua Voluntários de São Paulo, mostrando a praça Dom José Marcondes em primeiro plano, Face Nordeste.

Figura 66 Vista aérea a partir do início da rua Bernardino de Campos, mostrando a praça Dom José Marcondes em primeiro plano, Face Norte, para onde estão voltadas as praças do sol. À direita está o boulevard comercial.

Figura 67 - Vista aérea da praça mostrando mapa de sombras e vegetação no inverno.

Figura 68 Vista aérea da praça mostrando mapa de sombras e vegetação em dia de verão. 
Figura 69 Vista a partir da rua Bernardino de Campos, "calçadão", orientação Noroeste.

Figura 70 Vista a partir da rua Voluntários de São Paulo, orientação Sudeste. $\quad 146$

Figura 7I Vista externa a partir da rua Pedro Amaral, Nordeste. $\quad 146$

$\begin{array}{ll}\text { Figura } 72 \text { Vista externa a partir da rua Silva Jardim, Sudoeste. } & 147\end{array}$

Figura 73 Vista externa a partir da rua General Glicério, Noroeste. 147

Figura 74 Vista externa a partir da rua XV de Novembro, Sudeste $\quad 147$

Figura 75 Vista da Praça Rui Barbosa a partir da rua Voluntários de São Paulo. Arborização existente, ampliação de piso vegetal, criação de praça de acesso com equipamento modular de micro-comércio (bloco azul). 147

Figura 76 Vista da Praça Dom José Marcondes a partir do terraço-jardim da laje da igreja. Aumento de área permeável e vegetação arbórea e coberturas para proteção solar em madeira laminada colada $(\mathrm{MCL})$ nas praças do sol. 148

Figura 77 - Vista do terraço jardim e mirante sobre a laje da igreja $\quad 149$ 


\section{LISTA DE TABELAS}

Tabela I Caracterização dos climas tropicais. Fonte: adaptado de Bustos Romero (1988).

Tabela 2 Elementos de clima a serem controlados em clima tropical. Fonte: adaptado de Bustos Romero (1988)

Tabela 3 Principais elementos e fatores climáticos e introdução de princípios de desenho urbano. Fonte: adaptado de Bustos Romero (1988)

Tabela 4 Princípios para regiões de clima quente-seco. Fonte: adaptado de Bustos Romero (1988)

Tabela 5 Princípios para regiões de clima quente-úmido. Fonte: adaptado de Bustos Romero (1988)

Tabela 6 Princípios para regiões de clima quente-úmido. Fonte: adaptado de Bustos Romero (1988)

Tabela 9 Elementos que conformam o espaço. (ROMERO, 200I) p. I54..55

Tabela I0 Ficha bioclimática do espaço público,. (BUSTOS ROMERO, 200I, p.I58)

Tabela II - Temperatura do ar média e umidade relativa média em todos os períodos, dias e horários, para cada ponto de medição.

Tabela 12- Velocidade do vento em todos os períodos, dias e horários, para cada ponto de medição

Tabela 13 - Relação entre a velocidade média do vento e a percepção do usuário.

Tabela 14 - Percepção da umidade e umidade relativa do ar nos três pontos de medição.

Tabela 15 Aplicação de roteiro de estudo bioclimático ao processo de projeto

Tabela 16 Aplicação de roteiro de princípios bioclimáticos ao processo de projeto urbano. 



\section{INTRODUÇÃO}

Esta pesquisa busca contribuir com estudos sobre arquitetura de espaços livres, pressupondo o impacto de suas configurações no conforto urbano e o papel potencial do projeto, enquanto ferramenta para intervir na criação de ambientes urbanos de maior qualidade e mais adequados ao uso das pessoas. A pertinência do tema está relacionada à atual discussão sobre os processos de urbanização e configuração das cidades, sob o ponto de vista social, econômico e ambiental.

Após rápido processo de expansão ocorrido na segunda metade do século $X X$, a transformação da maioria das cidades brasileiras foi marcada pela deterioração do meio ambiente e pela desigualdade social. Segundo relatório UN-Habitat' (ONU, 2012), quase $80 \%$ da população da América Latina vive em cidades, numa proporção maior do que o grupo de países mais desenvolvidos, razão pela qual a região é considerada a mais urbanizada do mundo. Entretanto, a partir de uma perspectiva demográfica, este relatório afirma que a explosão urbana está em declínio e os processos de urbanização estão praticamente concluídos em todos os países da região. Desde o ano 2000, a média anual da taxa de crescimento populacional urbano tem sido menos do que dois por cento, valor que corresponde a população natural. A princípio, esta desaceleração do crescimento pode ajudar a evitar os problemas associados ao crescimento rápido, permitindo concentrar esforços na melhoria espaços urbanos,

\footnotetext{
${ }^{1}$ The State of Latin American and Caribbean Cities 2012 - Towards a new urban transition
} 
infraestruturas e serviços existentes. No entanto, o espaço construído continua a se expandir. Conforme exposto no documento citado, as cidades se expandem fisicamente a taxas que podem ser de duas ou três vezes maiores do que a taxa de aumento da população, resultando numa redução da densidade populacional. Esta redução da densidade significa um aumento em toda infraestrutura, colocando um novo desafio para o universo das cidades. Além da expansão do tecido urbano, as áreas centrais vivem um processo de mudança de uso, apropriações e degradação.

As cidades médias e pequenas, onde a maioria da população urbana vive, têm crescido a uma taxa um pouco maior do que as grandes cidades. Este grupo de cidades com populações entre 20.000 e 500.000 habitantes corresponde a $47 \%$ da população urbana brasileira, dado que mostra a necessidade de estudos sobre estes padrões urbanos e busca por soluções para problemas próprios a este universo.

O centro urbano das cidades vem sendo tratado com maior preocupação urbanística desde a década de 60. Na Europa, as estratégias de renovação passam a ser substituídas pelas de reabilitação, com entendimento de valores espaciais, urbanísticos e culturais. (LAMAS, 2000). A crise energética e econômica contribuiu para esta mudança, já que o custo financeiro e ambiental de renovação é maior que o de reabilitação urbana. Após a década de 70, a percepção dos limites do crescimento econômico condicionaram os programas urbanísticos e os grandes empreendimentos passaram a ser questionados. Para Lamas (2000), “os grandes temas do planejamento deslocaram-se da escala regional para a escala do bairro e do 
lugar". Passou a ser questionado o controle da cidade por planos regionais e planos diretores e, discutida a necessidade de pequenas intervenções em equipamentos urbanos por meio da reabilitação, voltando a atenção ao “interior das cidades e qualificação de seus espaços”.

A preocupação na busca de novas matrizes energéticas para a construção de edifícios e cidades também contribuiu com uma importante mudança. Nos últimos 30 anos, a arquitetura passou a rediscutir sua relação com a cidade e com seu meio, em busca de soluções estratégicas na obtenção de eficiência energética. Os estudos sobre clima e a criação de tecnologias com soluções passivas para o conforto ambiental de edifícios avançaram muito neste período. Estudos sobre o impacto do clima urbano, conforto de espaços abertos e experiências de projeto urbano têm sido objetos de pesquisas em diversos países.

Aos espaços livres das cidades corresponde a relação do conjunto edificado com o meio circundante, quer públicos ou privados, têm um importante papel na qualidade do ambiente urbano. Lugar da vida urbana, estes espaços possuem usos e funções diversas: social, institucional, ambiental, mobilidade, recreação e outros. Com o reconhecimento da importância dos espaços livres para as pessoas, os projetos passaram a ter um maior cuidado nos aspectos de planejamento e adequação à escala de seus usuários. Gehl (20l3) fala do dimensionamento dos espaços urbanos como fator crucial para que estes cumpram sua função como arcabouço das atividades humanas. Ou seja, o espaço urbano requer um desenho que 
considere as atividades básicas e universais do homem, tais como caminhar, andar, sentar, olhar, ouvir e falar.

O conforto e bem-estar humano nos espaços livres está diretamente relacionado ao microclima, que é o clima em uma atmosfera local e restrita. Ao microclima urbano corresponde uma condição particular, em um ambiente urbano pequeno, de variáveis climáticas que influenciam as condições de conforto térmico e as necessidades de energia para o aquecimento ou resfriamento das edificações.

O entendimento do microclima pode se constituir em uma ferramenta útil para o projetista criar ambientes termicamente confortáveis e energeticamente eficientes em edificações e espaços externos. Seu estudo e aplicação são mais complexos em espaços abertos do que em edifícios, em função de um maior número de variáveis espaciais.

A fim de revitalizar cidades e aumentar o uso de espaços urbanos, estudos sobre climatologia urbana permitem realizar uma análise térmica de espaços abertos e gerar diretrizes para projeto urbano. KATZCHNER (2000) afirma que planejar espaços abertos requer uma análise microclimática precisa como também, uma avaliação do comportamento das pessoas na dependência de determinada situação térmica.

No Brasil, estudos na área mostram que a mudança climática local está associada aos efeitos de transformação de energia na área urbana. (ASSIS). O ritmo das atividades humanas concentradas nos centros urbanos corresponde a importante fonte de calor e determina as alterações no microclima das cidades. O conhecimento e aplicação de conceitos de 
conforto ambiental em projeto urbano é uma resposta necessária e propositiva ao complexo cenário das cidades contemporâneas.

No que diz respeito a trabalhos de arquitetura, atender a esta demanda e atuar neste cenário requer dos projetistas considerar a complexidade e a devida qualidade de projetos, pressupondo o bem-estar humano como requisito de atividades de pesquisa e projeto. Em estudo sobre metodologias de projeto arquitetônico, KOWALTOWSKI ET AL (2006) apontam dois aspectos importantes a serem considerados neste processo: a colaboração entre os agentes de um projeto para produzir com eficiência e qualidade e a exigência de aperfeiçoar procedimentos e incorporar metodologias mais sistemáticas de pesquisa e projeto ao processo. Ou seja, o processo de projeto, devidamente orientado, tem um papel fundamental a realizar.

Sendo assim, o objetivo principal desta pesquisa é gerar diretrizes de projeto para uma área localizada no centro da cidade de São Jose do Rio Preto, considerando a influência que as diferentes morfologias de espaços livres provocam no microclima.

Os objetivos específicos da pesquisa são: I. Verificar como a morfologia dos espaços livres interfere no microclima em cada uma das configurações analisadas; 2. Experimentar métodos de avaliação de conforto urbano e construir uma base de dados do local de estudo proporcionando subsídios a pesquisas ou projetos futuros; 3 . Investigar e aplicar ferramentas que permitam integrar ao processo de projeto, métodos de adequação bioclimática de espaços livres urbanos. 
A hipótese da pesquisa é que em um mesmo ambiente climático, as diferentes configurações da morfologia urbana modificam as condições microclimáticas e de conforto, interferindo na qualidade e uso dos espaços livres.

Ciente da complexidade do tema deste estudo, não se pretendeu esgota-lo neste trabalho. Desde o início, a intenção foi a de relacionar microclima urbano e espaços livres na busca de subsídios para atividades aplicadas ao projeto. Acredita-se que a criação de ambientes urbanos confortáveis pode resultar em uma cidade mais adequada ao uso humano não apenas pelo resultado obtido pela melhoria de seus espaços livres, mas também pela contribuição que estes espaços adequadamente ocupados possam trazer para o conjunto edificado da cidade.

A estrutura da dissertação está organizada em quatro capítulos, além de introdução. $O$ primeiro capítulo apresenta $\circ$ referencial teórico da pesquisa. O segundo apresenta a metodologia adotada e descreve a caracterização do objeto de estudo, o terceiro apresenta as análises e suas conclusões e o quarto capítulo discute os resultados, propõe diretrizes e apresenta uma aplicação do desenvolvimento teórico do trabalho por meio de uma proposta de intervenção bioclimática para o local objeto de estudo. 


\section{ARQUITETURA DE ESPAÇOS LIVRES: INTERFACE ENTRE PROJETO E CONFORTO URBANO}

\section{I.I ESPAÇOS LIVRES: DEFINIÇÕES E RELAÇÃO COM A CIDADE}

Os conjuntos urbanos edificados pela intervenção do homem ao longo de sua história mostram uma relação de cheios e vazios, de espaços edificados e espaços livres de edificação.

"O espaço livre é todo espaço não ocupado por um volume edificado (espaço-solo, espaço-água, espaçoluz) ao redor das edificações a que as pessoas têm acesso. " (MAGNOLI, 1982).

Ashihara (1982) entende o espaço exterior como um espaço criado ao delimitar a natureza. Rodeado por seu marco, o espaço exterior desenvolve dentro de si uma ordem centrípeta, constitui um espaço positivo com funções e fins humanos. Por outro lado, a natureza é um espaço centrífugo que se prolonga até o infinito e se considera como espaço negativo. Ao diferenciar o espaço exterior da arquitetura, como aquele desenhado em duas dimensões, a arquitetura sem teto, o autor mostra a importância do cuidado ao materializar o plano horizontal, utilizando materiais naturais e artificiais integrados ao meio com uma ordem de intenções. 

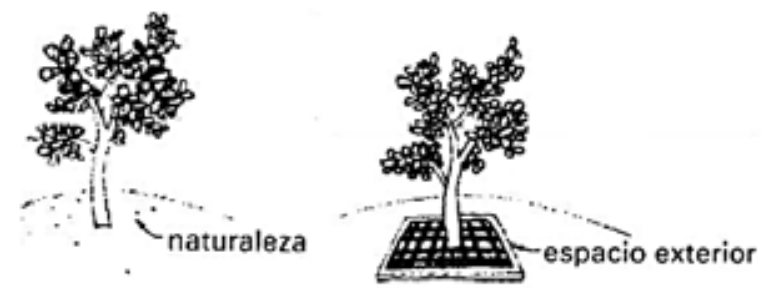

Figura I Entendimento de Ashihara (1982) sobre espaço exterior como espaço criado para delimitar a natureza.

O espaço livre difere-se pela presença ou ausência de volumetria e edificação. Inseridos no contexto urbano, Macedo (1995) denomina de espaços livres todas as ruas, praças, largos, pátios, quintais, parques, jardins, terrenos baldios, corredores externos, vilas, vielas, entre outros. Para o autor, as áreas verdes, áreas de lazer, espaços verdes e áreas de circulação são apenas tipos de espaços livres. Para o autor, estes termos não contém uma denominação precisa, já que "nem todas as praças são áreas de lazer e/ou necessitam ser ajardinadas para desempenhar seu papel de espaço social.“. (MACEDO, 1995).

Para Bustos Romero (200I), a definição de espaço exterior é paralela à noção de espaço arquitetônico, com uma diferença significativa, a noção de envolvente. A autora denomina de espaços públicos exteriores aqueles espaços que condicionam os espaços construídos, conferindo-lhes formas e características. O espaço livre é assim entendido como forma definida, "pensada e construída com tanta intenção como a de um edifício".

Os espaços livres urbanos são resultantes de determinado modelo de desenvolvimento e urbanização. No Brasil da década de 50, quando 
surgiram as principais linhas do paisagismo contemporâneo, houve uma ruptura com o padrão hierarquizado da cidade tradicional. O cenário urbano ideal passa a ser constituído de edifícios isolados e espaços livres contínuos e indefinidos, com amplos arvoredos e muita área verde. (MACEDO, 1995). As superquadras de Brasília tornam-se o modelo de urbanismo a ser adotado como padrão por todo país. No entanto, quando aplicado nas cidades tradicionais, esta concepção vai aos poucos sendo substituída por outra que possa atender as necessidades sociais de uso de cada lugar.

No Brasil, os espaços livres de edificação se estruturam em função de uma forma quase única de parcelamento do solo, que privilegia os lotes alinhados lado a lado, tendendo a retangulares e possuindo as laterais maiores, perpendiculares às vias públicas. (MACEDO, 1995). Criado no final do século $X I X$, este padrão pressupõe a existência de um edifício colocado no meio do lote e demais áreas de jardim, e foi consolidado como espaço ideal para a moradia de bairros-jardim. Estas variações morfológicas foram adotadas na maioria das cidades brasileiras onde aos poucos, o padrão colonial de assentamento, caracterizado pelo fechamento do lote em relação à vida pública, foi sendo abandonado. (MACEDO, 1995).

Importante diferenciar as configurações paisagísticas das áreas horizontalizadas e verticalizadas. A princípio, o padrão de assentamento de edifícios adotado nas maiores cidades brasileiras, corresponde ao alinhamento dos prédios na rua, geralmente geminados, formando pátios 
internos nas quadras para as funções de insolação e ventilação. Esta estrutura morfológica, que pode ser observada nas áreas centrais das cidades brasileiras, passou a ser questionada na segunda metade do século $X X$, com a introdução do urbanismo modernista. As quadras modernas verticalizadas, com o edifício afastado do lote, passaram a ser uma referência para um novo padrão de assentamento. (MACEDO, 1995). Para a legitimação deste padrão, é criada uma legislação urbanística em São Paulo, que tinha como exigência principal o recuo obrigatório e a ocupação máxima de $50 \%$ do lote, o que resultou na existência de generosos espaços livres privados. Este padrão de assentamento foi adotado como modelo de expansão pela maior parte das cidades brasileiras, onde hoje se pode observar a inexistência de sistemas de espaços livres públicos e a escassez de espaços públicos para lazer e convívio da população. (MACEDO, 1995). $\mathrm{Na}$ cidade tradicional, os espaços livres compõem-se de espaço público e espaço privado, onde a área do solo privado é maior. $O$ urbanismo moderno provocou uma redução do espaço privado em detrimento de amplos espaços públicos, que exigiam altos custos de construção e manutenção. Por outro lado, o modelo de desenvolvimento urbano moderno proporcionou a ocupação das cidades pelos carros e a concentração de funções comerciais e de serviços em grandes centros privados.

Os elementos que definem os espaços livres obedecem a lógicas relacionadas a formas de parcelamento e propriedade do solo. (MACEDO, 1995). Estas formas de apropriação condicionam toda a constituição 
morfológica urbana. Ou seja, a morfologia da paisagem é sempre coerente ao extrato social que a produz, possui uma identidade e pode ser percebida na configuração dos espaços livres, ou seja, na largura de ruas e calçadas, nas espécies vegetais e forma de plantio, na arquitetura de seu entorno construído, entre outros.

A qualidade do espaço nas cidades é influenciada pela configuração do espaço livre, diz Magnoli (1982) e por esta razão não pode ser exclusivamente decorrência do desenho do espaço edificado. Nesta abordagem, o espaço livre corresponde ao espaço urbano associado às edificações e que está subordinado às atividades dos usuários e edifícios de seu entorno e diretamente relacionado ao modelo urbano onde tem valor quantitativo e qualitativo. (MAGNOLI, 2006).

\section{I.2 MORFOLOGIA URBANA E ARQUITETURA DA CIDADE}

"A forma da cidade corresponde à maneira como se organiza e se articula a sua arquitetura.“ Aldo Rossi

Por meio de sua arquitetura, a cidade desenha e caracteriza seu espaço urbano. Para Lamas (2000), a forma urbana é o modo como se organizam os elementos morfológicos que constituem e definem o espaço urbano em relação aos aspectos de organização funcional e quantitativa, dos aspectos qualitativos e figurativos. "A forma, sendo objetivo final de toda concepção está em conexão com o desenho (no sentido de projeto)”. (LAMAS, 2000). Esta noção de forma não se restringe apenas às características perceptíveis dos objetos e entende a arquitetura como disciplina de análise e concepção 
de espaço. $O$ autor adota algumas referências que apoiam a compreensão sobre a morfologia urbana, subdividindo-a em quatro aspectos.

I. Aspecto Quantitativo: Relacionado a tudo que pode ser quantificável: densidade, superfícies, fluxos, coeficientes de volumes, dimensões e outros que podem controlar os aspectos físicos da cidade.

2. Aspecto Funcional: Relacionado com as atividades humanas (habitar, trabalhar, etc.) e com o uso a que é destinado.

3. Aspecto qualitativo: Refere-se ao tratamento dos espaços, ao conforto do usuário, como por exemplo, a adaptação ao clima, acessibilidade, inclusão e podem ser quantificáveis.

4. Aspecto figurativo refere-se à comunicação estética.

Identificar os elementos morfológicos pressupõe conhecer as partes da forma e o modo como se articulam em suas diferentes escalas.

"Sendo a leitura e composição urbanas essencialmente arquitetônicas, podemos aplicar ao espaço urbano os mesmos métodos interpretativos da arquitetura." (LAMAS, 2000)

Assim como na arquitetura, os elementos morfológicos são relativamente constantes no espaço urbano. $O$ modo como se estruturam e se organizam gera uma comunicação estética, no caso da cidade, como obra coletiva, provém dos objetos - edifícios e da sua articulação com o espaço por eles definidos. A relação entre os tipos edificados e o modo com se agrupam condicionam a forma urbana. Esta interdependência entre arquitetura e 
cidade, mostra que a forma urbana é resultado, produto e geradora da tipologia edificada.

As relações entre os elementos morfológicos com as dimensões ou escalas do espaço urbano levou o autor a organizar hierarquicamente a forma urbana para estuda-la e melhor compreende-la. Denominou de dimensão setorial ou escala da rua, em que os elementos morfológicos são os edifícios, o traçado, as árvores, o desenho do solo e o mobiliário urbano. À dimensão urbana, ou escala do bairro correspondem os traçados, praças, quarteirões e áreas verdes. $\mathrm{Na}$ dimensão territorial ou escala urbana, os elementos morfológicos são os bairros, a infraestrutura viária, as grandes áreas verdes e as estruturas da paisagem.

Para Lamas (2000), a produção da cidade é de domínio arquitetônico, em um processo que deveria ser liderado pelo desenho desde a fase do desenho até a realização das construções. A simples existência de duas construções em proximidade é suficiente para que se estabeleçam relações visuais, estéticas e ambientais que são de domínio da arquitetura.

Dentre os elementos da forma urbana, a praça distingue-se pela organização espacial e intencionalidade do desenho. A praça pressupõe uma forma e um programa. Se as ruas são os lugares de circulação, a praça é o lugar tradicional do encontro, da permanência, dos acontecimentos, e práticas sociais. Seu significado como espaço coletivo a diferencia de outros vazios na estrutura da cidade. (LAMAS, 2000).

As estruturas verdes constituem elementos identificáveis na estrutura urbana, caracterizam a imagem da cidade, têm individualidade própria, 
desempenham funções precisas como elementos de composição e de desenho urbano; servem para organizar, definir e conter espaços. A estrutura verde não tem a mesma "dureza" ou permanência que as partes edificadas da cidade, mas situa-se ao mesmo nível da hierarquia morfológica e visual. (LAMAS, 2000).

O desenho do espaço urbano trabalha os elementos edificados e as estruturas verdes como elementos da mesma área de atuação, mesmo que exijam conhecimentos específicos e disciplinares diferenciados. A morfologia urbana tem importante papel na determinação do ambiente e microclima dos espaços urbanos. A articulação de seus elementos, por meio do desenho pode favorecer a qualidade do ambiente urbano que depende diretamente da forma, distribuição e orientação das edificações. A configuração física dos espaços livres de edificações está diretamente relacionada à distribuição do espaço das edificações e dos espaços livres, ou seja, ela depende do espaço edificado. (MAGNOLI, 2006).

\section{I.3 ARQUITETURA DE ESPAÇOS LIVRES}

Inúmeras são as funções dos espaços livres, o que permite classificá-los. No entanto, eles podem apresentar-se como espaços multifuncionais e atender a diversos papéis no contexto da vida urbana. A qualidade de determinados espaços livres urbanos está relacionada à possibilidade de apropriação que estes permitem a seus usuários. Quanto mais e melhor puder ser apropriado, maior será sua aceitação social e por mais tempo será mantida sua identidade morfológica. (MACEDO, 1995). O autor apresenta três 
fatores fundamentais a serem considerados na avaliação de espaços livres: I. Adequação funcional, que corresponde à correta conformação morfológica e dimensional que permite sua utilização para determinado fim;

2. Adequação ambiental, que permite ao usuário condições de salubridade para o desempenho de suas atividades (condições de sombreamento, ventilação adequada, permeabilidade do solo e outros.) e 3. Adequação estética, relacionada aos padrões de aceitação formal de determinada época.

Gehl (20l3) afirma que o pré-requisito para a existência da vida urbana corresponde à adequação dos espaços livres às atividades humanas. Para o autor, estas atividades podem ser organizadas em três categorias, entendidas dentro de uma escala, conforme seu grau de importância. São elas: I. Atividades necessárias: aquelas obrigatórias que acontecem sob qualquer condição; 2. Atividades opcionais: geralmente recreativas onde a qualidade do espaço urbano é fundamental para que ela aconteça; e 3. Atividades sociais: pressupõem a cidade como lugar de encontro e para que ocorram, é imprescindível a existência das atividades necessárias e sociais. Em seu estudo, o autor relaciona o desempenho das atividades humanas em espaços livres à qualidade do ambiente físico.

Diversos estudos sobre os espaços livres urbanos já foram realizados, quer seja sob o enfoque da percepção do usuário como Lynch ou Cullen, ou a partir de avaliação empírica. Entretanto, a maior parte das teorias encontra-se no meio acadêmico e quase não são aplicadas ao cotidiano de projeto urbano para gerar novos espaços livres públicos ou privados. $\bigcirc$ 
espaço livre ainda é visto como espaço residual e não é reconhecido como elemento de projeto urbano pelos profissionais de arquitetura e urbanismo, pelo público usuário e pela grande maioria dos gestores públicos. Macedo (1995) ressalta a necessidade de revisão de padrões de projeto dos espaços livres, procurando adequá-los ao contexto do território onde está localizado.

\subsection{Bioclimatismo}

O termo "projeto bioclimático" foi utilizado para designar a arquitetura em harmonia com o meio natural (OLGYAY, 1963). Ela trata da relação entre o usuário e as condições climáticas, de forma que a arquitetura atue como um filtro das condições externas. $\mathrm{O}$ bioclimatismo busca uma solução de projeto, pressupondo o clima e que resulte na obtenção de conforto ambiental e redução de consumo de energia.

Quando aplicado ao espaço urbano, a concepção bioclimática incorpora os elementos ambientais ao processo de projeto, identificando e sistematizando instrumentos de desenho urbano que possibilitem criar espaços adequados ao seu meio e realidade. Ao formular seu conceito de bioclimatismo, Romero articula três referências como base para o tratamento do espaço: a otimização das relações energéticas com o meio através do desenho arquitetônico, a recuperação da influência do lugar não apenas do ponto de vista climático, mas também histórico e cultural e a resposta local que resulta em solução regional. 
“... a arquitetura bioclimática é uma forma de desenho lógico que reconhece a persistência do existente, é culturalmente adequada ao lugar e aos materiais locais e utiliza a própria concepção arquitetônica como mediadora entre o homem e o meio.” (ROMERO -200 I, p.28)

\section{I.4 MICROCLIMA URBANO E CONFORTO EM ESPAÇOS LIVRES}

\subsection{Estudos aplicados de microclima urbano}

O microclima urbano corresponde à condição em que as variáveis climáticas como radiação solar, temperatura do ar, velocidade do vento e umidade relativa sofrem modificações na área construída e criam um clima diferente em um ambiente urbano restrito. (BUSTOS ROMERO, 200I). No microclima estão refletidos os efeitos e a influência das atividades humanas sobre o entorno e correspondem a um clima com características próprias, observadas em recintos determinados como praças, ruas, jardins, parques e outros. (BARBIRATO, 20II).

Fatores relacionados à morfologia urbana e a configuração espacial dos recintos urbanos, como topografia, vegetação, tipo de solo, capacidade térmica de materiais de superfícies, podem modificar o clima de uma região. (LECHNER, N., 2000). E este microclima modificado influencia o conforto térmico e consequentemente, a energia requisitada para aquecimento ou resfriamento das edificações e dos ambientes externos. 
Os efeitos da urbanização nos elementos climáticos e ambientais podem ser observados principalmente no vento, que por sua vez, é o elemento climático que mais pode ser controlado e modificado pelo desenho urbano. A morfologia urbana é um elemento importante na determinação dos microclimas da cidade, na medida em que a quantidade de radiação solar incidente e o regime de ventos no ambiente urbano dependem diretamente da forma, distribuição e orientação das edificações. (BARBIRATO, 20II). A orientação das ruas, o tamanho, altura e densidade dos edifícios, a distribuição entre edifícios altos e baixos têm grande impacto nas condições urbanas do vento. (BUSTOS ROMERO, 200I).

O entendimento do comportamento do microclima e sua relação com os atributos da morfologia urbana podem se constituir em ferramenta importante no projeto de edificações e espaços externos. O microclima pode ser modificado por meio de um planejamento adequado, resultando na obtenção de conforto térmico nos espaços livres. A necessidade de refrigeração de espaços livres em regiões de clima quente e com alta umidade relativa do ar pode ser atendida por meio do incremento da ventilação e da prevenção contra ganhos de calor, com recursos de sombreamento.

As características morfológicas do ambiente urbano determinam o desempenho microclimático dos recintos urbanos. O comportamento térmico deste ambiente é definido pelo acesso da radiação solar, das áreas sombreadas, da orientação dos edifícios e espaços externos em relação ao sol e ao vento. (MASCARÓ, 2002). As propriedades térmicas dos materiais 
das fachadas e superfícies de recobrimento do solo e a geometria do entorno construído também influenciam o desempenho do microclima. Conhecer estes fenômenos e identificar as características climáticas locais é da máxima importância para evitar o desconforto térmico dos espaços livres urbanos.

\subsubsection{Arquitetura de espaços livres e sua influência na qualidade térmica urbana}

O projeto de arquitetura tem por atribuição inerente, estabelecer condições mínimas de conforto térmico e qualidade ambiental aos edifícios. Por sua vez, o desenho dos edifícios é o principal responsável pela configuração dos ambientes urbanos, configurando o entorno construído dos espaços livres de edificação. Sendo assim, a compreensão das relações entre as edificações e o microclima urbano é necessária também para a concepção do projeto de arquitetura de edifícios. $O$ ato de construir modifica o clima urbano e o projetista é responsável não apenas pelas condições internas, mas também pela produção de um entorno climático externo. (BUSTOS ROMERO, 200I). O estudo sobre o clima é importante ferramenta para a obtenção de condições de conforto térmico em espaços internos e externos e na criação de soluções passivas na busca de eficiência energética do ambiente construído. Desta forma, este estudo procurou estabelecer um parâmetro para entendimento do clima e aplicação em projeto baseado na classificação climática de Bustos Romero (1988). 
Os climas podem ser classificados conforme a temperatura (quente, temperado, frio); amplitude térmica (continental, oceânico); umidade (seco, úmido); precipitações (desértico, árido, chuvoso) e outros. Existem vários sistemas de classificação de clima aceitos (KOEPPEN, 1948; BUSTOS ROMERO, 1988) para zonas de clima tropical.

\section{Tabela I Caracterização dos climas tropicais. Fonte: adaptado de Bustos} Romero (1988)

\section{Quente e úmido}

Pequenas variações de temperatura durante o dia. Amplitude das variações diurnas fracas. Temperatura amena à noite com umidade elevada.

Duas estações: verão e inverno, com pequena variação de temperatura entre elas; período de chuvas indefinido com maiores precipitações no verão.

Radiação difusa intensa. Conteúdo do vapor d'água das nuvens evita a radiação direta intensa.

Alto teor de umidade relativa do ar.

Ventos fracos, direção dominante sudeste.

\section{Quente e seco}

Grandes amplitudes de temperatura durante o dia $\left(15^{\circ} \mathrm{C}\right)$. No período seco, durante o dias máximas alcançam valores extremos e à noite decrescem alcançando valores mínimos.

Duas estações: uma seca e outra de chuva. No período de chuva, estes não alcançam os valores de umidade das regiões tropicais úmidas.

\section{Pouca radiação difusa em} virtude da umidade baixa. Radiação direta intensa.

Baixo teor de umidade relativa do ar.

Massas de ar quente conduzindo partículas de pó em suspensão no período seco.

\section{Tropical de altitude}

As amplitudes podem alcançar valores consideráveis. Há desconforto pela temperatura elevada do dia, minorado à noite, baixando aquém dos limites de conforto.

Duas estações: quente-úmida com início no verão e seca no inverno. Temperatura média entre 19 e $26^{\circ} \mathrm{C}$ durante $\mathrm{O}$ dia caindo à noite.

Radiação difusa intensa no verão e menor no inverno. Radiação direta acentuada no verão.

Pelo teor de umidade é considerado seco.

Ventos sudeste e leste no inverno seco e noroeste no verão chuvoso. 
Tabela 2 Elementos de clima a serem controlados em clima tropical. Fonte: adaptado de Bustos Romero (1988)

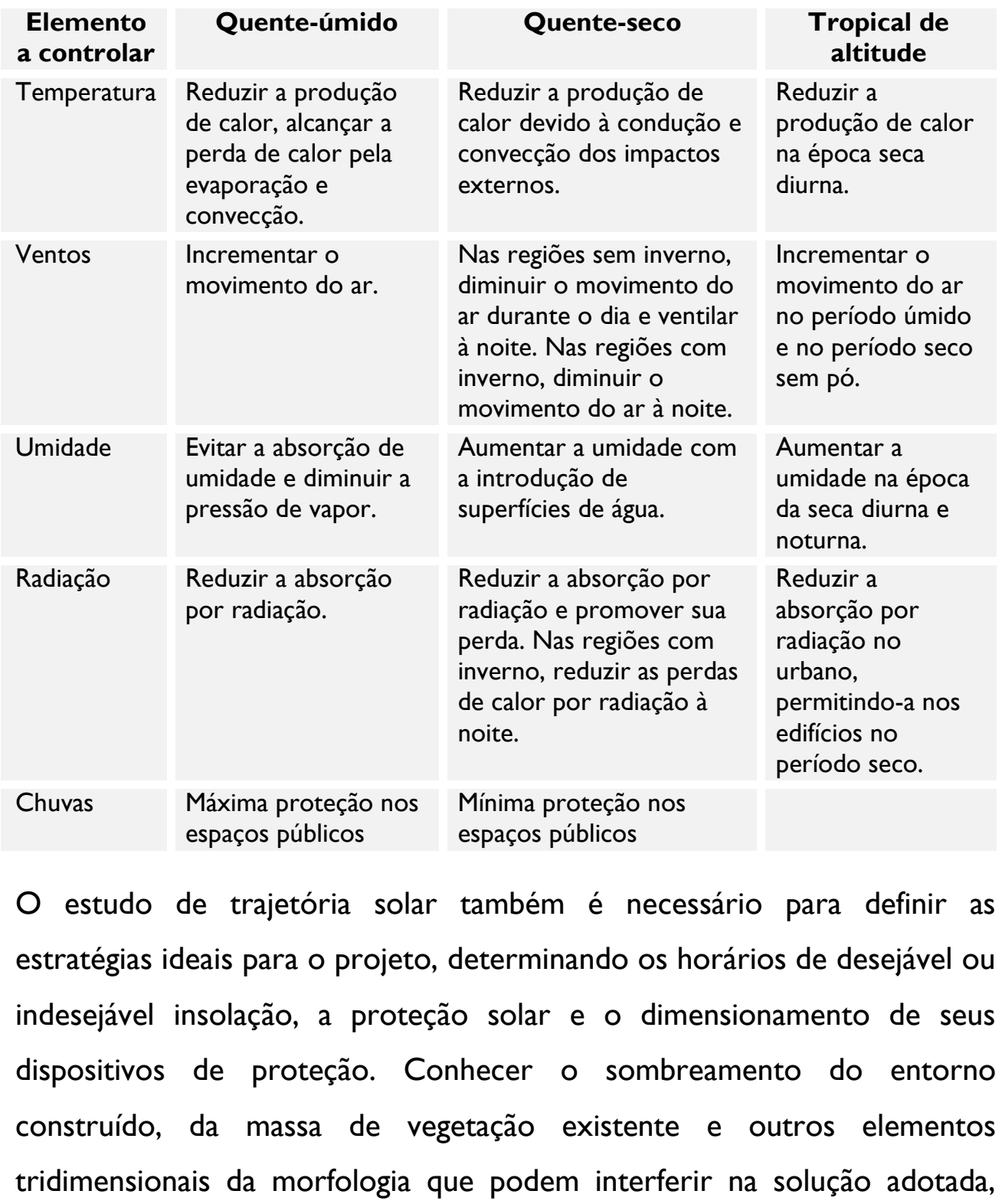


além da análise de fatores do sítio como topografia são fatores que devem ser considerados ao fazer um projeto climático. (BARBIRATO, 20I I).

\section{I.5 PRINCÍPIOS DE DESENHO URBANO}

Ao incorporar princípios bioclimáticos para o desenho urbano, é necessário considerar alguns princípios, independentemente do tipo de clima da região tropical em estudo. Estes princípios podem controlar os elementos e fatores climáticos que exercem grande influência no equilíbrio térmico entre o homem e o ambiente: são eles a radiação, a ventilação e a vegetação. (BUSTOS ROMERO, 1988).

Tabela 3 Principais elementos e fatores climáticos e introdução de princípios de desenho urbano. Fonte: adaptado de Bustos Romero (1988)

\section{Influência}

Radiação

Vegetação
Radiação solar direta e difundida pela atmosfera; raios solares refletidos pelas superfícies do entorno.

Positiva :

Aproveitamento para a ventilação urbana

Sombreamento;

Redução de

temperatura;

\section{Princípios para o desenho urbano}

Uso de materiais pouco refletivos; Uso de vegetação que absorve a radiação solar; Criação de fachadas irregulares para minorar os efeitos da reflexão da radiação solar.

Controle de efeitos aerodinâmicos através da massa edificada.

Depuração e fixação de contaminantes; proporcionar sombreamento atenuando os efeitos da radiação solar no verão; Captação de sol de inverno por meio de espécies decíduas; Controle de ventos indesejáveis 


\section{I.5. I Princípios para as regiões tropicais de clima quente- seco}

Estas regiões apresentam grande variação climática e as exigências para os períodos quentes são maiores do que a dos períodos frios. É necessário aumentar o grau de umidade do ar por meio de vegetação e água, além da proteção da radiação solar através de sombreamento e superfícies claras.

Tabela 4 Princípios para regiões de clima quente-seco. Fonte: adaptado de Bustos Romero (1988)

\section{Princípio para escolha do sítio}

Localização protegida contra o vento nas horas frias, contra o sol no período quente e captação do sol no período frio

Localização com aproveitamento das depressões de modo a beneficiar-se dos fluxos de ar frio para regiões sem inverno

Orientação Norte para o hemisfério Sul e Sul para o hemisfério Norte para proteção dos ventos frios.

Proteção contra a poeira e ventos quentes diurnos.

Uso de fontes e espelhos d'água para umidificação do ar urbano.

Espaços compactos que preservem o calor, bem como ondulações suaves e naturais que permitam armazenar umidade.

\section{Morfologia do tecido urbano}

Forma da estrutura urbana compacta, com o mínimo de exposição à radiação solar Para regiões com período frio prever superfícies para exposição ao sol nestes períodos.

Ruas estreitas, curtas e com mudança de direção para impedir a penetração de ventos indesejáveis.

Ruas com orientação que permita sombreamento.

Adotar lotes estreitos e longos com edificações contíguas.

Espaços públicos devem ser pequenos, utilizar pátios com água e vegetação para umidificação e outros dispositivos de sombreamento.

\subsubsection{Princípios para as regiões tropicais de clima quente-úmido}

Estas regiões apresentam pequena variação de temperatura diária, a radiação difusa é intensa e a umidade do ar elevada. De forma geral, o objetivo de controle deve ser diminuir a temperatura, melhorar o 
movimento do ar, evitar a absorção de umidade, proteger das chuvas e promover seu escoamento rápido.

Tabela 5 Princípios para regiões de clima quente-úmido. Fonte: adaptado de Bustos Romero (1988)

\section{Princípio para escolha do sítio}

Locais altos e abertos aos ventos.

Orientação segundo direção dos ventos predominantes.

Uso das declividades naturais do sítio para escoamento das águas de chuva.

\section{Morfologia do tecido urbano}

Tecido urbano disperso, aberto, de forma a permitir a ventilação das estruturas urbanas.

Construções esparsas com presença de vegetação para sombreamento / absorção de radiação solar.

Ruas orientadas de modo a permitir sombreamento dos espaços externos (utilizar elementos sombreadores: marquises, vegetação).

Alinhamento irregular das edificações / permitir circulação do ar entre as edificações.

Em áreas pouco adensadas utilizar lotes mais largos que compridos.

\subsubsection{Princípios para as regiões tropicais de clima tropical de altitude}

As regiões tropicais dos planaltos ou tropical de altitude apresentam características do clima quente e úmido no período chuvoso, e do clima quente e seco no período seco. As exigências de conforto para o dia e para a noite não são as mesmas. 
Tabela 6 Princípios para regiões de clima quente-úmido. Fonte: adaptado de Bustos Romero (1988)

Princípio para escolha do sítio

Arranjo livre, liberdade formal devido ao clima ameno.

Aproveitamento dos ventos no período quente e dispositivos de proteção nas edificações para os períodos frios.

\section{Morfologia do tecido urbano}

Traçado com pátio para umidificação (benefício no período seco).

Proteção contra excesso de radiação diurna e diminuição das perdas noturnas.

Ruas: uso de vegetação para sombreamento através de espécies que permitam ao mesmo tempo sol no inverno.

Tecido urbano pouco compacto permitindo resfriamento das estruturas / evitar canalização excessiva dos ventos.

Os espaços de uso público devem ser abertos com presença de vegetação / utilizar superfícies (gramados, por exemplo) que impeçam a reflexão para as construções, a excessiva absorção da radiação solar e o aumento das temperaturas das superfícies próximas.

\subsection{A VEGETAÇÃO URBANA}

A vegetação atua nos microclimas contribuindo com a melhoria do ambiente urbano como um termorregulador microclimático, modificando o albedo das superfícies, ao interferir na radiação recebida durante o dia e perdida durante a noite. (MASCARÓ, 2002). Entre seus benefícios, a vegetação ameniza a radiação solar na estação quente e modifica a temperatura e umidade relativa do ar através do sombreamento; modifica a velocidade e direção dos ventos e reduz a poluição do ar por meio da fotossíntese e da respiração. Os efeitos do resfriamento passivo das ruas pelo sombreamento da vegetação contribuem para minimizar a influência da geometria do espaço urbano no microclima e atenuar a variação da 
temperatura do ar como resultado do aumento do atraso térmico ${ }^{2}$. (MASCARÓ, 2002).

A influência da vegetação na temperatura do ar está relacionada com o controle e transformação da radiação solar do vento e da umidade do ar. A radiação de onda curta que incide nas folhas é parcialmente transmitida como radiação difusa, pois a folha não é opaca à radiação solar. Depende da transparência, cor, espessura das folhas que absorvem. (MASCARÓ, 1996). A radiação absorvida é transformada parte em calor físico e parte em energia química e depende da pigmentação das folhas que absorvem, em média, $50 \%$ da radiação de onda curta e $95 \%$ da radiação de onda longa. A eficácia do desempenho da vegetação está diretamente relacionada à espécie escolhida, que podem captar sol no inverno ou proteger do sol no verão. A vegetação tem menor capacidade calorífica e condutividade térmica do que os materiais de construção presentes na cidade. Uma árvore pode controlar a radiação solar direta que chega até o solo, diminuindo o calor irradiado a partir deste, e consequentemente, diminui a temperatura do ar próxima. A radiação solar incidente é absorvida pelas folhas, que possuem baixo índice de reflexão (albedo baixo). A taxa de evaporação é muito mais alta nas áreas verdes do que nas plantas. As árvores interceptam uma quantidade de radiação solar direta, e, dependendo da densidade de sua folhagem e extensão e espessura de sua copa, pode alcançar valores altos de radiação absorvida, sendo uma parte 
refletida para cima e o resto absorvido pela própria árvore, a fim de ser utilizada nos processos de transpiração e fotossíntese. (ROMERO, 200I). Mascaró (2002) faz uma série de recomendações sobre o sombreamento urbano, tais como limitar a incidência dos raios solares em pelo menos $2 / 3$ da área de circulação de pedestres, praças e estacionamentos no período quente; garantir a insolação em locais de recreação infantil, pelo menos por quatro horas no período frio; garantir a insolação das fachadas norte, leste e oeste pelo menos por duas horas no inverno quando o sol está próximo ao meio dia.
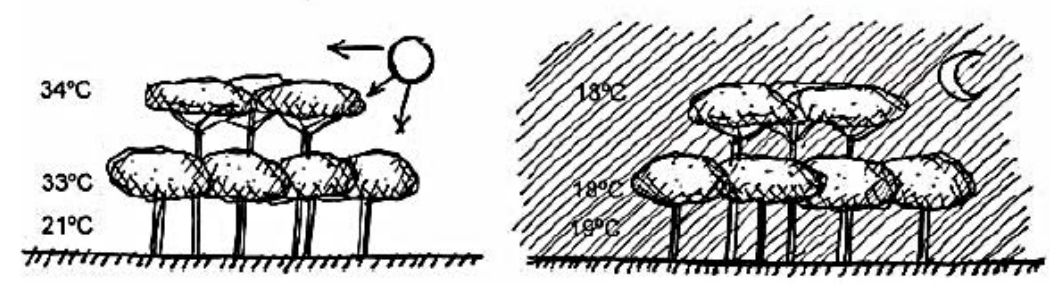

Figura 2 Efeito de agrupamentos arbóreos na temperatura do ar nos períodos diurno e noturno.

Os agrupamentos arbóreos constituídos por espécies de diferentes portes contribuem para a redução da temperatura, já que as várias camadas da copa ampliam a absorção da radiação. Além de interceptar a radiação solar e modificar as características do vento, a vegetação reduz a incidência da precipitação sobre o solo e altera a concentração de umidade na atmosfera e superfícies adjacentes. (MASCARÒ, 1996). A vegetação contribui para maior umidade relativa do ar e está relacionada à evapotranspiração, que depende da morfologia da folha. 


\section{I.6. I Vegetação e vento}

O vento exerce importante papel na sensação de conforto, pois regula a sensação térmica ao estimular a evaporação e a perda de calor por convecção. As barreiras com vegetação podem produzir efeitos adequados às configurações dos espaços urbanos. Mascaró (1996) cita quatro destes efeitos: obstrução, que é o bloqueio do fluxo de ar; a deflexão, que desvia o fluxo de ar e com isso reduz sua velocidade; a filtragem, reduz a velocidade de acordo com a permeabilidade da barreira e a condução, que direciona o fluxo, modificando sua velocidade.
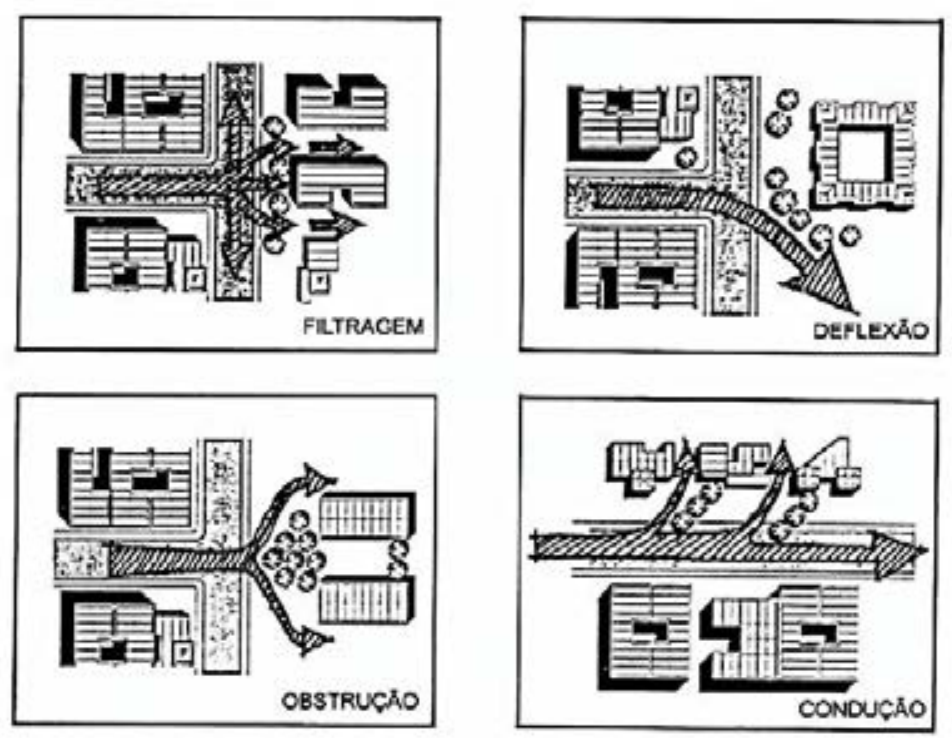

Figura 3 Efeitos da vegetação na modificação da direção e velocidade dos ventos. Fonte: Mascaró, 1996. 


\section{OBJETO DE ESTUDO}

Neste capítulo, apresentam-se de forma detalhada, quais os procedimentos utilizados no desenvolvimento deste trabalho, compreendendo aqueles que fundamentaram o referencial teórico, como também, aqueles responsáveis pela coleta e análise dos dados. A opção por um objeto modelo para estudo deveu-se à intenção inicial deste trabalho em experimentar a aplicabilidade da base teórica em procedimentos de projeto. Sendo assim, este capítulo apresenta a metodologia utilizada, o levantamento e caracterização do espaço urbano objeto de estudo.

\section{I METODOLOGIA}

\section{I. I Método proposto por Katzchner (1997)}

Foram adotados dois métodos de análise do espaço urbano. $O$ primeiro deles foi desenvolvido pelo professor Lutz Katzchner, da Universidade de Kassel na Alemanha (KATZCHNER, 1997), que propõe avaliar as condições de clima urbano pela descrição qualitativa e de um sistema de classificação espacial baseado no padrão térmico do ambiente urbano. A primeira etapa corresponde à elaboração e análise de mapas de topografia, uso do solo, gabarito, estruturas da cidade, altura das edificações, vegetação e recobrimento do solo. Em seguida é feita uma descrição qualitativa do espaço, realizada através de medições e posterior análise de variáveis ambientais e sensações humano-biometeorológicas. metodologia propõe o monitoramento ambiental envolvendo o usuário na 
avaliação das condições microclimáticas e de conforto do ambiente. $O$ levantamento de campo é a espinha dorsal do projeto, um estudo integrado do ambiente urbano e das condições de conforto. A investigação tem por objetivo produzir uma diretriz para o projeto urbano, oferecendo meios adequados para avaliar o desenvolvimento da cidade e tomar decisão de projeto e planejamento. Para Katzchner (1997), o planejamento do espaço aberto requer uma análise precisa do microclima local e uma avaliação do comportamento das pessoas na dependência daquela condição térmica. Para isto, foi desenvolvida uma metodologia para o mapeamento das condições de conforto no contexto urbano a partir de medições e observações.

A metodologia de mapeamento das condições de conforto no contexto urbano é desenvolvida com base no levantamento da área. Para o levantamento da área deve-se obter um extensivo conjunto de dados referente às condições de conforto, uso do espaço e características do público. O levantamento combina duas principais questões, uma ambiental que é uma medida meteorológica do ambiente térmico e a outra através de observações e entrevistas com as pessoas. $O$ estudo tem sido realizado em qualquer estação do ano, em diferentes condições de tempo, obtidos os dados considerando a manhã, hora do almoço e período da tarde. Desta forma, o levantamento da área supre informações sobre os parâmetros climáticos (temperatura do ar e de globo, umidade, velocidade do vento, radiação global, etc.) e sua variação no tempo e no espaço. 
Os dados do clima são relacionados com os resultados das entrevistas e observações levantadas na área junto às características do sítio. Assim, é necessário relacionar o comportamento humano, a estrutura morfológica e o conforto térmico enquanto dados. Desta forma, a avaliação da situação de conforto térmico poderá gerar recomendações de planejamento. Neste caminho, o levantamento da área corresponde a uma importante base para o desenvolvimento e verificação da metodologia de mapeamento de conforto.

Tabela 7 - Conexão entre aspectos de planejamento e clima urbano elaborada a partir de KATZCHNER (1997)

METAS DE
PLANEJAMENTO
Redução da poluição
do ar
Desenvolvimento
da vida urbana
Melhoria na qualidade
de espaços externos

$\quad$ FERRAMENTAS
CLIMÁTICAS URBANAS
Análise do padrão de
vento

Análise da diversidade do clima

Análise de condições microclimáticas e forma de uso de espaços livres

\section{ESCALAS DE PLANEJAMENTO}

Desenvolvimento urbano $(\mathrm{I}: 25.000 \mathrm{a}$ I:10.000)

Planejamento de espaços livres ( I:2.000 a |:500)

Planejamento de espaços livres $(\mathrm{I}: 2.000$ a $\mathrm{l}: 500)$

A validação destes mapas encontra-se em um mapa de padrão climático que inclui todos os fatores influentes no clima urbano. A segunda etapa é o desenvolvimento de uma proposta de planejamento orientado ao clima com diferentes categorias que são áreas que poderiam ser protegidas ou melhoradas, áreas que são de importância para o microclima ou ainda áreas com condições climáticas negativas. A seguir, apresenta-se um esquema simplificado dos procedimentos recomendados no método de Katzchner. 
Tabela 8 - Fluxograma da metodologia de Katzchner ( 1997 ), adaptado por COSTA (2003)

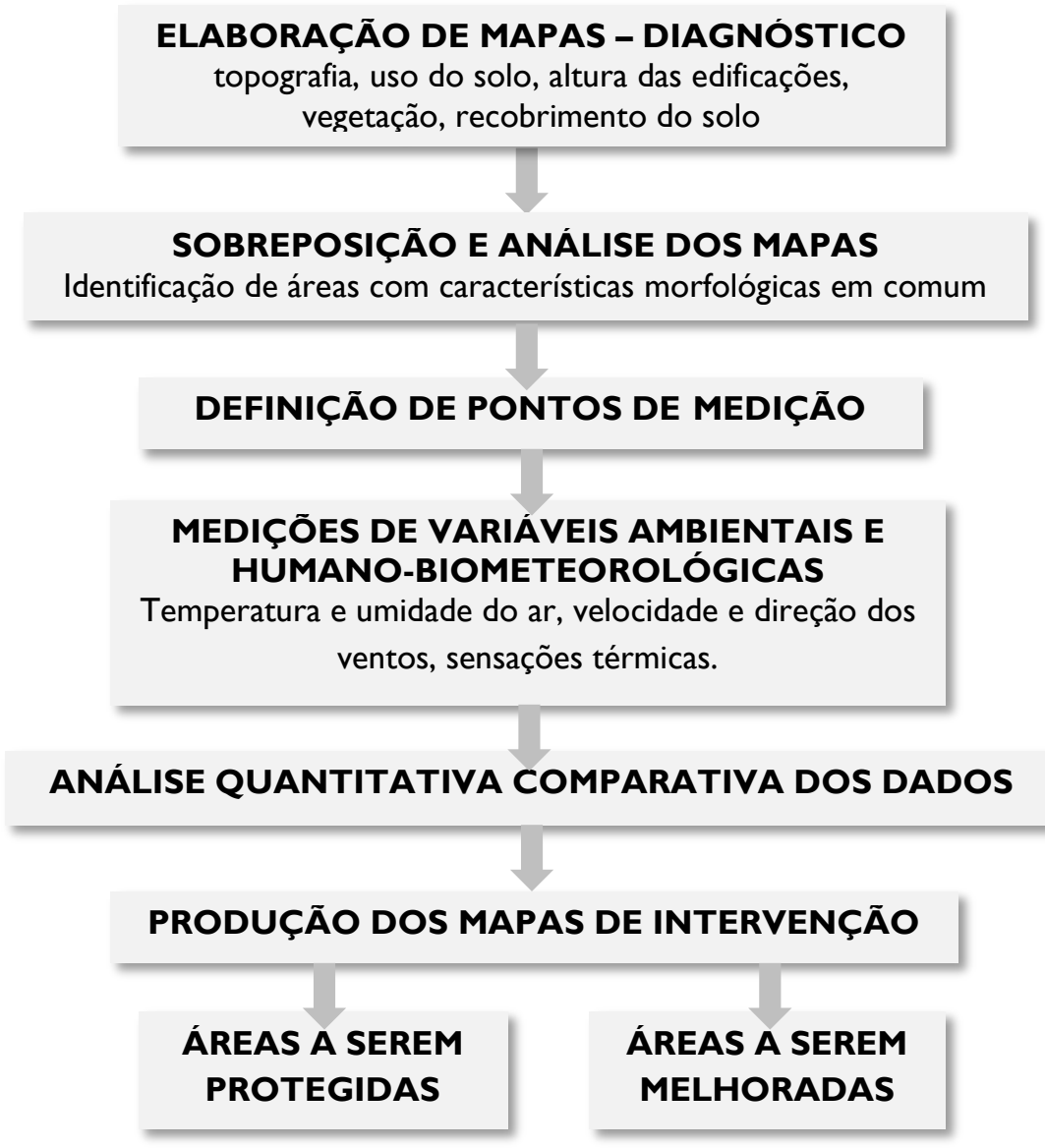

Com base na metodologia acima, a primeira etapa da pesquisa correspondeu à elaboração dos mapas com os atributos da área de estudo conforme as descrições a seguir apresentadas.

TOPOGRAFIA: Legenda com curvas de nível de 10 em 10 m 
USO DO SOLO: Organização dos lotes em usos comercial, residencial, serviços, industrial, institucional, vazios e praças.

ALTURA DAS EDIFICAÇÕES: Classificação em térreo, entre 2 e 4 pavimentos, entre 5 e 9 pavimentos e acima de 10 pavimentos.

GABARITO DE FIGURA-FUNDO: Identificação dos espaços edificados e espaços livres e a criação do mapa de espaços livres.

ÁREA VERDE OU VEGETAÇÃO: Locação das áreas verdes existentes através da projeção das copas e canteiros existentes.

TIPO DE RECOBRIMENTO DO SOLO: Apresentação dos diferentes tipos de materiais de recobrimento do solo, tais como área pavimentada, pavimento com asfalto, pavimento permeável ou semipermeável (bloco de concreto intertravado, pedra portuguesa ou concreto), área construída e área permeável (solo nu ou com vegetação).

\subsubsection{Análise bioclimática de espaços livres}

O segundo método adotado está baseado na concepção de espaço livre enquanto unidade, onde os elementos ambientais, climáticos, históricos, culturais e tecnológicos participam na ordenação do espaço. Trata-se da concepção bioclimática em escala urbana e visa transformar o espaço livre em um mediador entre o clima externo e o ambiente do interior do mesmo, assim como a arquitetura bioclimática o faz com o edifício. Os espaços públicos exteriores urbanos são espaços que condicionam os espaços construídos, são elementos essenciais na paisagem, com uma forma própria, pensada e definida com o mesmo detalhe de um edifício. 
Trata-se da concepção arquitetônica do espaço público proposta por Bustos Romero (200I). Neste método recorre-se à conjugação dos mais relevantes elementos formais do espaço do edifício e do espaço urbano.

As características de tamanho, densidade, orientação do construído, rugosidades aerodinâmicas, anteparo das emissões de radiação de onda larga, relacionamentos entre o tamanho dos edifícios, a distância entre eles, configuram-se como elementos que receberão o tratamento bioclimático. O ambiente e o espaço são as categorias temáticas a serem analisadas, caracterizadas em três partes: 0 entorno, a base e a superfície fronteira. (BUSTOS ROMERO, 200I). O entorno é o espaço urbano mais imediato do espaço livre; a base é o espaço sobre o qual está assentado o espaço livre; a superfície fronteira é o espaço limite ou marco arquitetônico de interesse.

A cada um destes componentes, correspondem elementos ambientais e espaciais. Ao entorno corresponde as condições de iluminação, exposição solar, ventilação e som e as características espaciais de massa construída, grau de adjacência, compacidade e altura dos espaços. A base inclui os elementos assentados, tais como pavimentos, vegetação, água, mobiliário urbano e as propriedades físicas dos materiais utilizados nos elementos. A fronteira compreende qualidades da superfície da pele dos edifícios como a convexidade, continuidade, tipologia arquitetônica, área total da envoltura, - céu, o grau de confinamento, entre outros. A autora ressalta a importância de tratar simultaneamente os componentes espaciais de base, entorno e fronteira, considerando as propriedades físicas dos materiais 
construtivos e os componentes ambientais, como clima, luz, cor e som sob uma concepção bioclimática que busca estabelecer uma relação entre arquitetura, lugar, cultura e bem-estar dos indivíduos.

Tabela 9 Elementos que conformam o espaço. (ROMERO, 200I) p. I54

\begin{tabular}{|c|c|c|c|}
\hline \multicolumn{2}{|r|}{ componente } & elementos espaciais & elementos \\
\hline$\frac{u}{n}$ & & $\begin{array}{l}\text { Coberturas (toldos, tendas, } \\
\text { pérgulas); Pavimentos, } \\
\text { Vegetação (tipo, altura, } \\
\text { tamanho das copas); } \\
\text { Mobiliário; } \\
\text { Água (lâminas, fontes, } \\
\text { cortinas, estanques, em forma } \\
\text { natural) }\end{array}$ & $\begin{array}{l}\text { Equilíbrio da } \\
\text { radiação e luz } \\
\text { natural; Natureza } \\
\text { dos elementos } \\
\text { superficiais; } \\
\text { Albedo: reflexão } \\
\text { e absorção da } \\
\text { radiação } \\
\text { incidente. }\end{array}$ \\
\hline 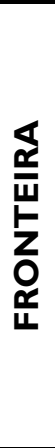 & & $\begin{array}{l}\text { Convexidade; Continuidade } \\
\text { da superfície, grau de } \\
\text { adjacência, porosidade; } \\
\text { Tipologia arquitetônica; } \\
\text { Detalhes dos edifícios: } \\
\text { pórticos, tribunas, marquises } \\
\text { galerias; Textura; Tensão, } \\
\text { progressão e regressão } \\
\text { Cores; Transparência, } \\
\text { opalescência; Número de } \\
\text { lados; Grau de confinamento. }\end{array}$ & $\begin{array}{l}\text { Propriedades } \\
\text { físicas dos } \\
\text { materiais; } \\
\text { Área total da } \\
\text { envoltória: perdas } \\
\text { e ganhos de calor } \\
\text { (reflexão e } \\
\text { absorção); }\end{array}$ \\
\hline 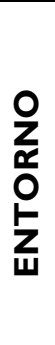 & & $\begin{array}{l}\text { Continuidade da massa, grau } \\
\text { de adjacência, compacidade; } \\
\text { Altura dos espaços. }\end{array}$ & $\begin{array}{l}\text { Orientação: sol, } \\
\text { ventos, som; } \\
\text { Condução dos } \\
\text { ventos do } \\
\text { entorno imediato } \\
\text { (entradas não } \\
\text { intencionais de } \\
\text { ar). }\end{array}$ \\
\hline
\end{tabular}


Romero (20II) propõe uma ficha analítica denominada ficha bioclimática do espaço público, para utilização como instrumento de registro sistemático de dados empíricos a serem coletados para posterior elaboração de projeto ambiental do espaço. Os elementos ambientais e espaciais são analisados por temas e entre eles há uma correspondência dada pelas características do entorno, base e fronteira. $O$ conjunto de dados da ficha bioclimática foi utilizado para caracterização de cada ponto de medição. 
Tabela 10 Ficha bioclimática do espaço público,. (BUSTOS ROMERO, 200I, p.158)

\begin{tabular}{|c|c|c|c|c|c|c|}
\hline \multicolumn{7}{|c|}{ FICHA BIOCLIMÁTICA DO ESPAÇO PÚBLICO } \\
\hline \multicolumn{4}{|c|}{ ESPACIAIS } & \multicolumn{3}{|c|}{ AMBIENTAIS } \\
\hline \multirow{7}{*}{ 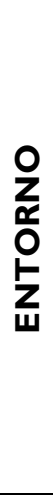 } & \multirow{5}{*}{ 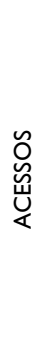 } & \multicolumn{2}{|c|}{ SOL } & \multicolumn{2}{|l|}{ SENSAÇÃO DE COR } & $\cup \circ$ \\
\hline & & \multicolumn{2}{|c|}{ VENTO } & \multicolumn{2}{|l|}{$\begin{array}{l}\text { RESSONÂNCIA } \\
\text { SOMBRA ACÚSTICA }\end{array}$} & 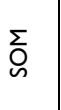 \\
\hline & & \multirow{3}{*}{\multicolumn{2}{|c|}{ SOM }} & DIREIA & \multirow{5}{*}{ 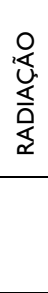 } & \\
\hline & & & & & & \\
\hline & & & & REFLE IISA & & \\
\hline & \multicolumn{3}{|c|}{ CONTINUIDADE DE MASSA } & \multirow{2}{*}{$\begin{array}{l}\text { UMIDADE RELATIVA } \\
\text { TEMPERATURA DO AR } \\
\text { VELOCIDADE DO VENTO }\end{array}$} & & $\stackrel{\Sigma}{J}$ \\
\hline & \multicolumn{3}{|c|}{ CONDUÇÃO DOS VENTOS } & & & \\
\hline \multirow{5}{*}{ 岁 } & \multicolumn{3}{|c|}{ ÁREA DA BASE } & \multicolumn{2}{|l|}{$\begin{array}{l}\text { TEMPERATURAS SUPERFICIAIS } \\
\text { ALBEDO }\end{array}$} & \\
\hline & \multirow{4}{*}{\multicolumn{2}{|c|}{ 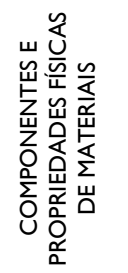 }} & PAVIMENTOS & \multicolumn{2}{|l|}{ AMBIENTE SONORO } & 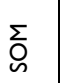 \\
\hline & & & VEGETAÇAO & \multirow{2}{*}{\multicolumn{2}{|c|}{$\begin{array}{l}\text { VARIAÇAO SAZONAL } \\
\text { TONALIDADE } \\
\text { CONJUNTO DE CORES }\end{array}$}} & \\
\hline & & & $\overline{A G U A}$ & & & U \\
\hline & & & $\begin{array}{l}\text { MOBILIÁRIO } \\
\text { URBANO }\end{array}$ & \multicolumn{2}{|l|}{$\begin{array}{l}\text { MANCHAS DE LUZ } \\
\text { ESTÉTICA DA LUZ }\end{array}$} & \\
\hline \multirow{7}{*}{ 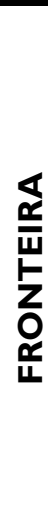 } & \multicolumn{3}{|c|}{$\begin{array}{l}\text { CONVEXIDADE } \\
\text { CONTINUIDADE DA SUPERFÍCIE }\end{array}$} & \multicolumn{2}{|l|}{ LUMINANCIA } & \\
\hline & \multicolumn{3}{|c|}{ TIPOLOGIA ARQUITETÖNICA } & \multicolumn{2}{|l|}{$\begin{array}{l}\text { INCIDENNCIA DA LUZ } \\
\text { DIREÇÃO DO FLUXO }\end{array}$} & $\stackrel{N}{د}$ \\
\hline & \multicolumn{3}{|c|}{$\begin{array}{l}\text { ABERTURAS } \\
\text { TENSÃO }\end{array}$} & \multicolumn{2}{|l|}{ ABSORÇÃO } & 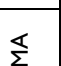 \\
\hline & \multicolumn{3}{|c|}{ DETALHES ARQUITETÖNICOS } & REFLEXÃO & & 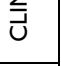 \\
\hline & \multicolumn{3}{|c|}{ NÚMERO DE LADOS } & $\begin{array}{l}\text { MATIZES } \\
\text { CLARIDADE }\end{array}$ & & Oั \\
\hline & \multicolumn{3}{|c|}{ ALTURA } & \multicolumn{2}{|l|}{ PERSONALIDADE ACÚSTICA } & \\
\hline & \multicolumn{3}{|c|}{ ÁREA TOTAL DA SUPERFÍCIE } & \multicolumn{3}{|c|}{ QUALIDADE SUPERFICIAL DOS MATERIAIS } \\
\hline
\end{tabular}




\subsection{CARACTERIZAÇÃO DO OBJETO DE ESTUDO}

Para estudo de campo foi escolhido uma área no centro urbano de São José do Rio Preto e delimitado como objeto modelo o espaço livre público correspondente às praças que deram origem à cidade.

O centro é um bairro localizado no espigão entre os córregos Borá e Canela, que se desenvolveu no início do século $X X$ e apresenta uma malha urbana ortogonal delimitada pelas avenidas de fundo de vale Alberto Andaló, Badi Bassit e Philadelfo Gouveia Neto. As quadras apresentam tamanhos regulares com lotes de tamanho também regulares, salvo algumas exceções, densamente ocupadas por edifícios de gabarito bastante diversificado (de I a 12 pavimentos).

O local delimitado para estudo é o principal espaço livre público do bairro, compreendendo as praças Rui Barbosa e Dom José Marcondes e a ligação entre elas pelo calçadão da Bernardino, contíguo a Igreja Matriz de São José. Ao norte encontra-se a Praça Cívica e o lago I da Represa, ambos integrantes do Parque Setorial. Ao Sul, tem-se a Praça do Fórum, espaço onde inexiste um espaço de convívio e permanência, possui área vegetação, calçadas para circulação e acessos e estacionamento de carros e alguns comércio como bancas de revistas. 


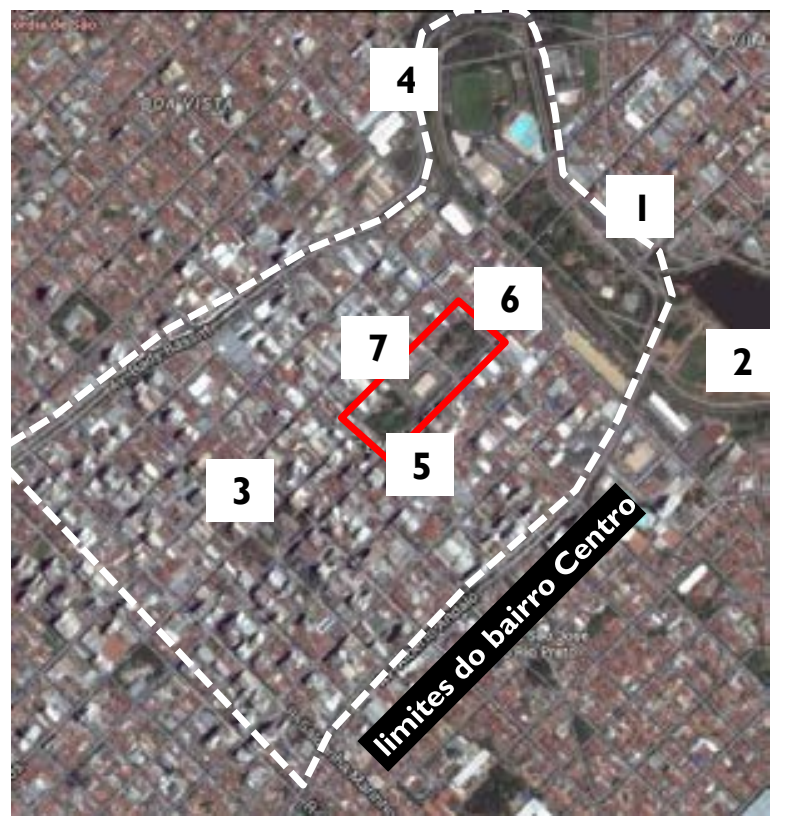

\section{LEGENDA}

$\square$ área de estudo

I. Praça Cívica

2. Parque Setorial

3. Praça do Fórum

4. Clube Palestra

5. Praça Rui Barbosa

6. Praça Dom José Marcondes

7. Calçadão da Bernardino

Figura 4 - Principais espaços livres na área central de São José do Rio Preto

Os pontos escolhidos para estudo atenderam aos critérios de tipologia ( 2 praças e uma rua de pedestres) e morfologia.

Além das medições de variáveis microclimáticas, foram levantadas as características morfológicas e realizadas entrevistas e observações de uso e comportamento do pedestre.

\subsection{São José do Rio Preto: aspectos físico-territoriais}

São José do Rio Preto, cidade do interior norte paulista, possui $94 \%$ de sua população de 408.435 habitantes (IBGE, 2010) vivendo em área urbana. e população estimada para 2014 de 438354 habitantes. A densidade demográfica do território é de 945,12 habitantes $/ \mathrm{Km}^{2}$. O município é sede 
da $8^{a}$ região administrativa e destaca-se por sua infraestrutura de bens e serviços diversificada. (CE-20I2).

\subsection{I.I Localização e clima}

A cidade está localizada no norte do estado de São Paulo, nas coordenadas geográficas $20^{\circ} 49^{\prime} \mathrm{II}$ ' latitude sul e $49^{\circ} 22^{\prime} 46^{\prime \prime}$ longitude oeste, em relevo de planalto, pouca ondulação, com amplos espigões e baixa altitude $(489 \mathrm{~m})$. O município pertence à bacia hidrográfica do Turvo Grande, sendo formada pelo rio Preto e seus principais afluentes: córregos do Macaco, da Lagoa ou da Onça, do Canela, do Borá, da Piedade, da Felicidade, São Pedro, da Anta e do Talhado e dois lagos artificiais formados pelo Rio Preto. O bioma é o Cerrado e Mata Atlântica, caracterizado também pela transição entre estes, o cerradinho e a capoeira, dependendo da fertilidade do solo e abastecimento hídrico. (CE2014).

Possui clima do tipo Aw, tropical chuvoso com inverno seco e ameno em que o mês mais frio apresenta temperatura média superior a $18^{\circ} \mathrm{C}$. $\mathrm{O}$ mês mais seco tem precipitação inferior a $60 \mathrm{~mm}$ e o período chuvoso estendese até o outono (CEPAGRI/KOEPPEN) . Sua temperatura média anual é de $23,67^{\circ} \mathrm{C}(2013)$, sendo que a média das máximas observadas no período foi de $30,30^{\circ} \mathrm{C}$ e a média das mínimas de $17,02^{\circ} \mathrm{C}$. Com grande variação pluviométrica (média anual de $1.385,70 \mathrm{~mm}$ ), possui um período extremamente chuvoso (dezembro a março) e outro extremamente seco (junho a agosto). O período chuvoso de verão, de outubro a março, corresponde aos meses mais quentes e o período mais seco, de inverno, 
de maio a agosto, apresenta temperaturas mais amenas. Devido a interferências atmosféricas regionais, os totais de chuvas anuais sofrem grande variação, de forma irregular. (CASTILHO, 2006).

Para efeito deste estudo e análise climática, foram considerados como dados de referências os arquivos climáticos em formato EPW ${ }^{3}$ gerados pela estação climatológica de José Bonifácio-SP, a mais próxima de São José do Rio Preto $(49 \mathrm{~km})$.

Os dados de temperatura, umidade relativa do ar e os índices de precipitação indicam temperaturas altas em quase todo o ano, mesmo em períodos de poucas chuvas e baixa umidade do ar.

\footnotetext{
3 Este conjunto de arquivos foi elaborado pelo Prof. Maurício Roriz, a partir de dados horários, registrados em $4 \mathrm{II}$ estações climatológicas do INMET entre os anos de 2000 e 2010 . O trabalho foi iniciado em abril de 2010, como parte das atividades do grupo constituído no âmbito da ANTAC para estudar a revisão do Zoneamento Bioclimático do Brasil (NBR I5220-3, ABNT 2005).

http://www.labeee.ufsc.br/downloads/arquivos-climaticos

http://www.labeee.ufsc.br/sites/default/files/arquivos_climaticos/sobre_epw.pdf
} 


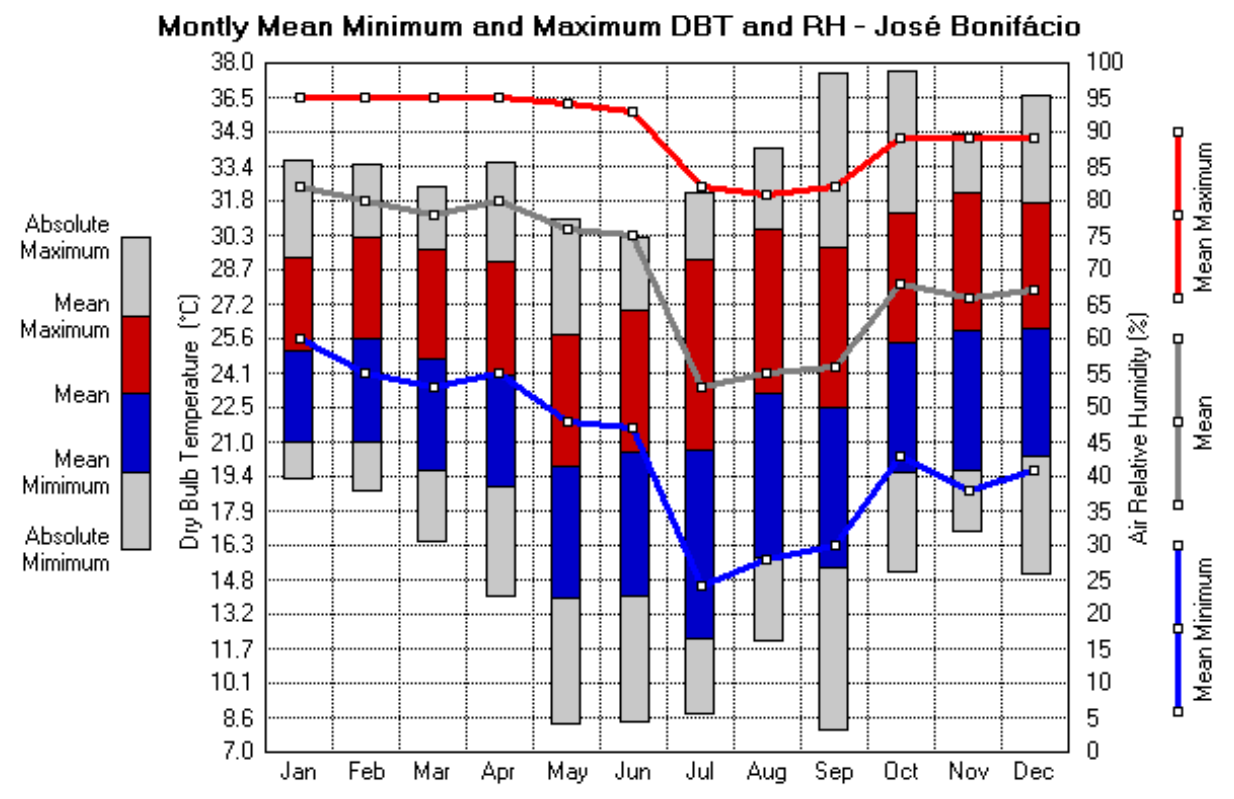

Figura 5 - Gráfico com a média mensal mínima e máxima de temperatura de bulbo seco e umidade relativa do ar. Fonte: arquivos climáticos gerados pela estação climatológica de José Bonifácio-SP LABEEE-UFSC

Com base nestes dados, nota-se que a umidade relativa do ar é menor no mês de julho seguida de agosto e setembro, exatamente na época em que a amplitude térmica é maior do que nos demais meses. Identifica-se assim que, mesmo com períodos mais secos, a umidade relativa do ar é considerada razoável em todo $\circ$ ano, não havendo a necessidade de prescrição de lâminas d'água para umidificação do ambiente. $\bigcirc$ maior índice de umidade relativa do ar é registrado nos meses de janeiro a abril. A menor média de temperatura observada é de $19,5^{\circ} \mathrm{C}$ no mês de maio e as mais altas temperaturas são observadas nos meses de outubro a 
dezembro. $O$ diagrama da carta solar associado às temperaturas de bulbo seco $^{4}$ (figuras 5 e 6) mostra o predomínio das temperaturas altas em quase todo o ano e leve redução de temperatura nos meses de maio a setembro.

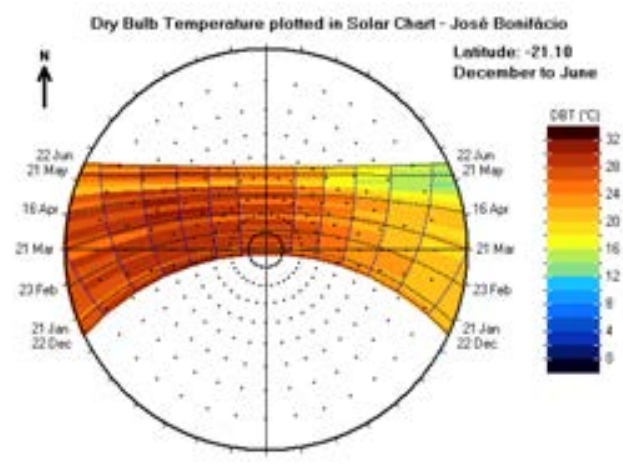

Figura 6 - Temperatura de bulbo seco plotada na carta solar no período de dezembro a junho - José Bonifácio. Fonte: arquivos climáticos gerados pela estação climatológica de José Bonifácio-SP; LABEEE-UFSC

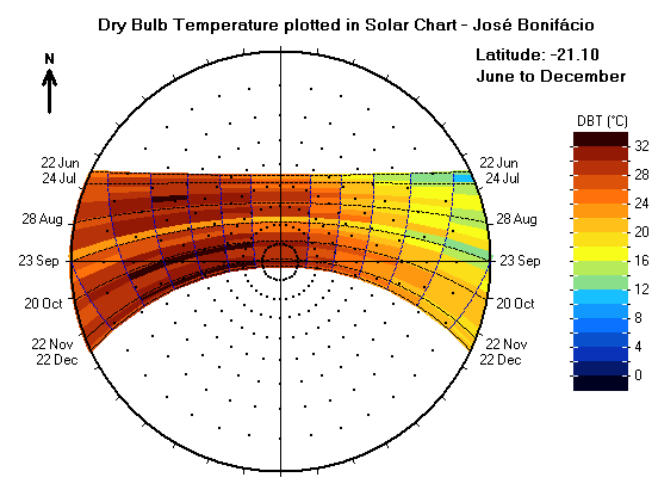

Figura 7 - - Temperatura de bulbo seco plotada na carta solar no período de junho a dezembro - José Bonifácio. Fonte: arquivos climáticos gerados pela estação climatológica de José Bonifácio-SP; LABEEE-UFSC

\footnotetext{
${ }^{4}$ A temperatura de bulbo seco mede a temperatura do ar sem considerar fatores ambientais como a radiação, umidade ou o movimento do ar, os quais têm potencial de afetar a sensação térmica. $O$ instrumento utilizado para medi-la é o termômetro de mercúrio, devidamente protegido da radiação e umidade.
} 


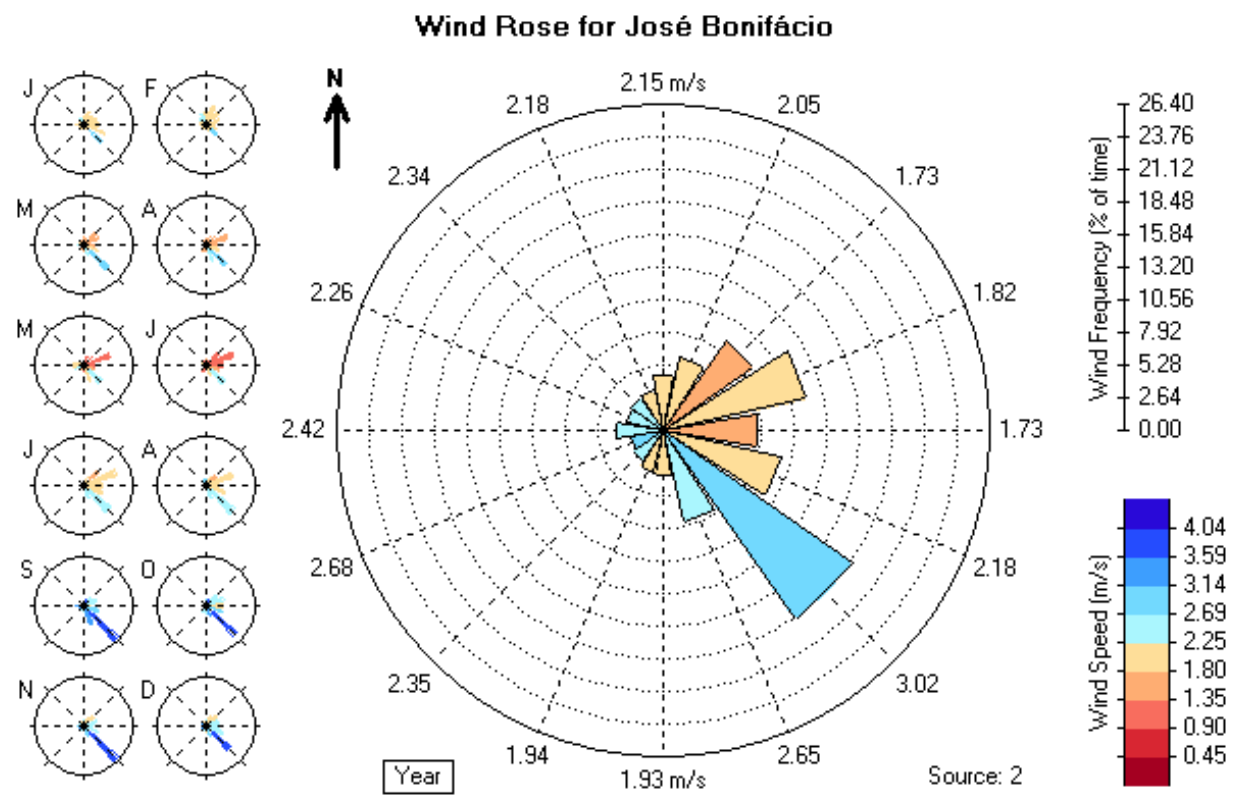

Figura 8 - Rosa dos Ventos para José Bonifácio Fonte: arquivos climáticos gerados pela estação climatológica de José Bonifácio-SP; LABEEE-UFSC

O gráfico acima mostra o predomínio de ventos de maior velocidade na direção sudeste nos meses de setembro a dezembro. De fevereiro a junho aparece com maior regularidade o vento nordeste e nos meses mais frios do inverno há uma mudança na intensidade e direção, variando entre nordeste e sudeste. Importante ressaltar que as características morfológicas urbanas podem modificar a intensidade e direção dos ventos registrados nas estações meteorológicas. 


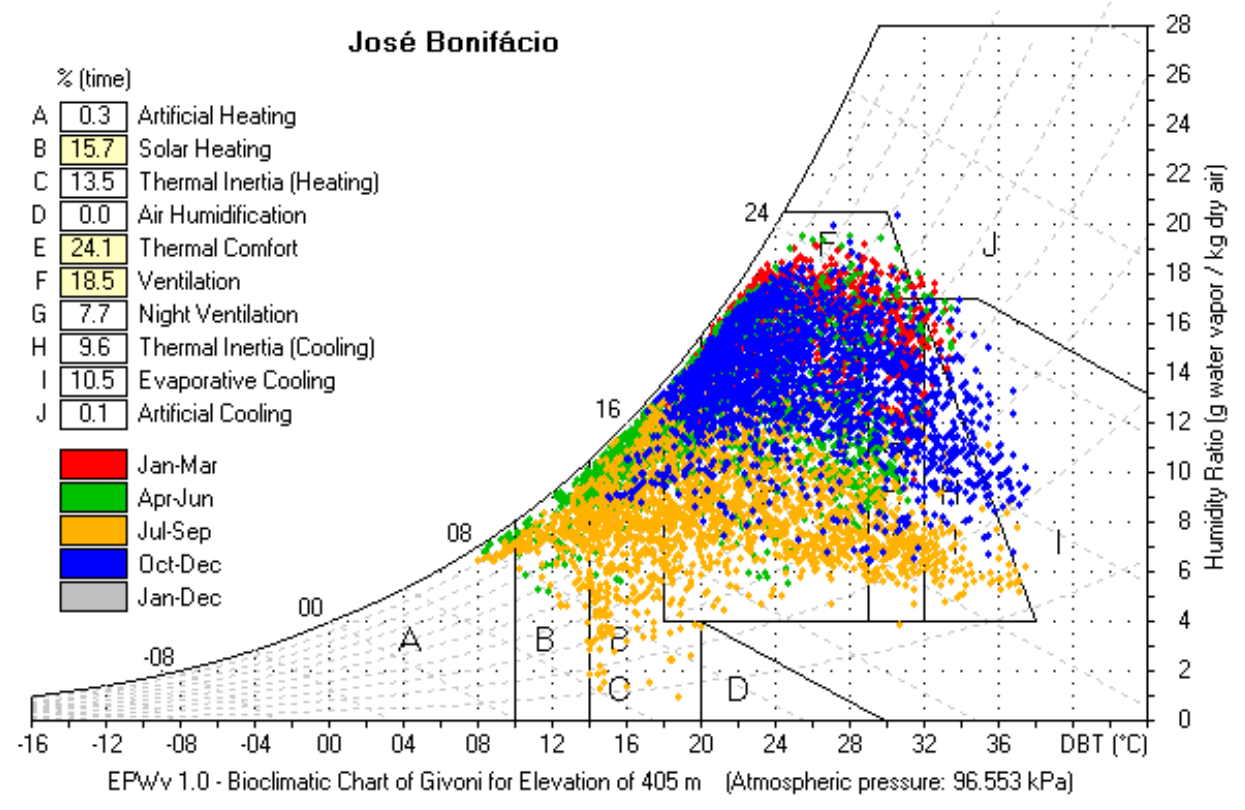

Figura 9 - Carta bioclimática para José Bonifácio. Fonte: arquivos climáticos gerados pela estação climatológica de José Bonifácio-SP; LABEEE-UFSC

\subsubsection{Aspectos históricos e urbanísticos}

Para efeito de entendimento da história do objeto de estudo, foram identificados quatro momentos fundamentais para sua configuração urbana, em que as ações destes decorrentes, causaram impactos importantes na morfologia da cidade e de seus espaços livres. Procurou-se assim, contar a história da cidade, sob a ótica do objeto de estudo, relatando através deste recorte, os momentos mais importantes do processo de urbanização.

São José do Rio Preto desenvolveu-se ao redor da primeira capela, local onde também foi criado um espaço livre público com relevante significado 
para a população. O primeiro momento foi em 1893, com a elaboração da planta da vila pelo engenheiro italiano Ugolino Ugolini, onde além do desenho do mapa, foi feito o registro cadastral com número de lotes e área em $\mathrm{m}^{2}$ e alqueires, informando o total do patrimônio em 868 alqueires.

Neste traçado urbano, foram destinadas quatro quadras para praças públicas. Através da Lei $N^{\circ} 294$, de julho de 1894 foi criado o município de São José do Rio Preto, que contava com 72 casas, 25 ruas e a praça central com o cruzeiro e a capela. A maioria das construções então realizadas, ocupavam toda a testada do lote e eram feitas sem recuos frontal ou lateral. A forma de ocupação do lote remetia à cidade colonial brasileira, em que o espaço livre do lote ficava atrás do edifício, no miolo da quadra, correspondendo a um pátio de serviços.

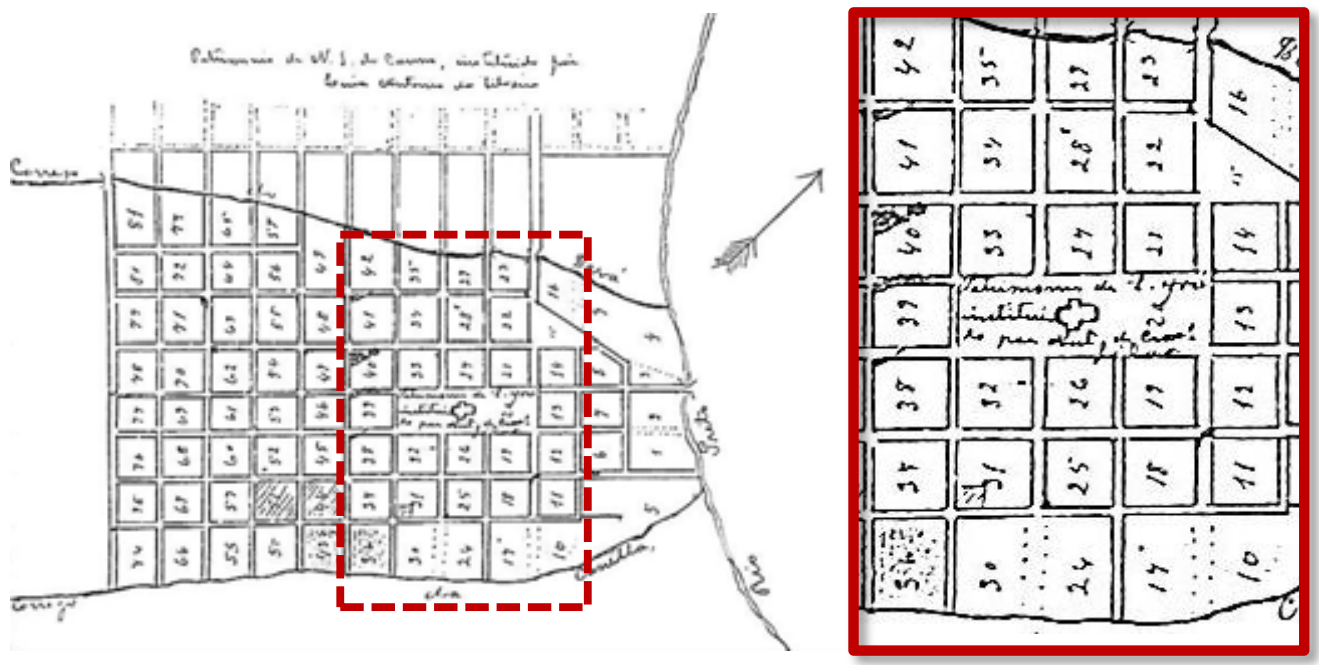

Figura 10 Primeiro mapa do Patrimônio de São losé elaborado por Ugolini em 1893 e indicação do núcleo urbano central e principais rios e córregos que delimitam a área. No detalhe ampliado, a indicação de área reservada às praças centrais. Fonte: BRANDI, 2002. 
O crescimento da cidade ao redor da Capela conduziu o traçado urbano da área central da cidade onde foram destinadas quatro quadras para praças públicas. Segundo LODI (2007) e imagens da época, o traçado foi pouco alterado. Em 1908 deu-se o início do ajardinamento da Praça da Matriz, trabalho realizado pelo engenheiro Ugolino Ugolini. recebendo um traçado simétrico e extensas áreas de vegetação. A Praça Rui Barbosa, delineada na planta de Ugolini em 1894, recebeu um traçado próprio em 1915, segundo LODI (2009), quando foram instalados bancos, fonte com chafariz e arborização.
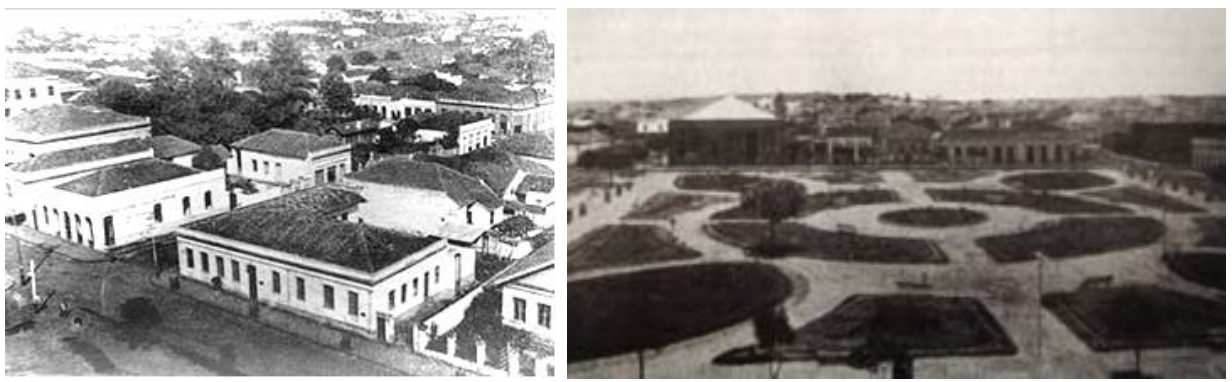

Figura II Esquina da Rua Siqueira Campos com Bernardino de Campos na década de 20. Fonte: Arquivo Público Municipal e Figura 12- Praça Rui Barbosa, 1918 


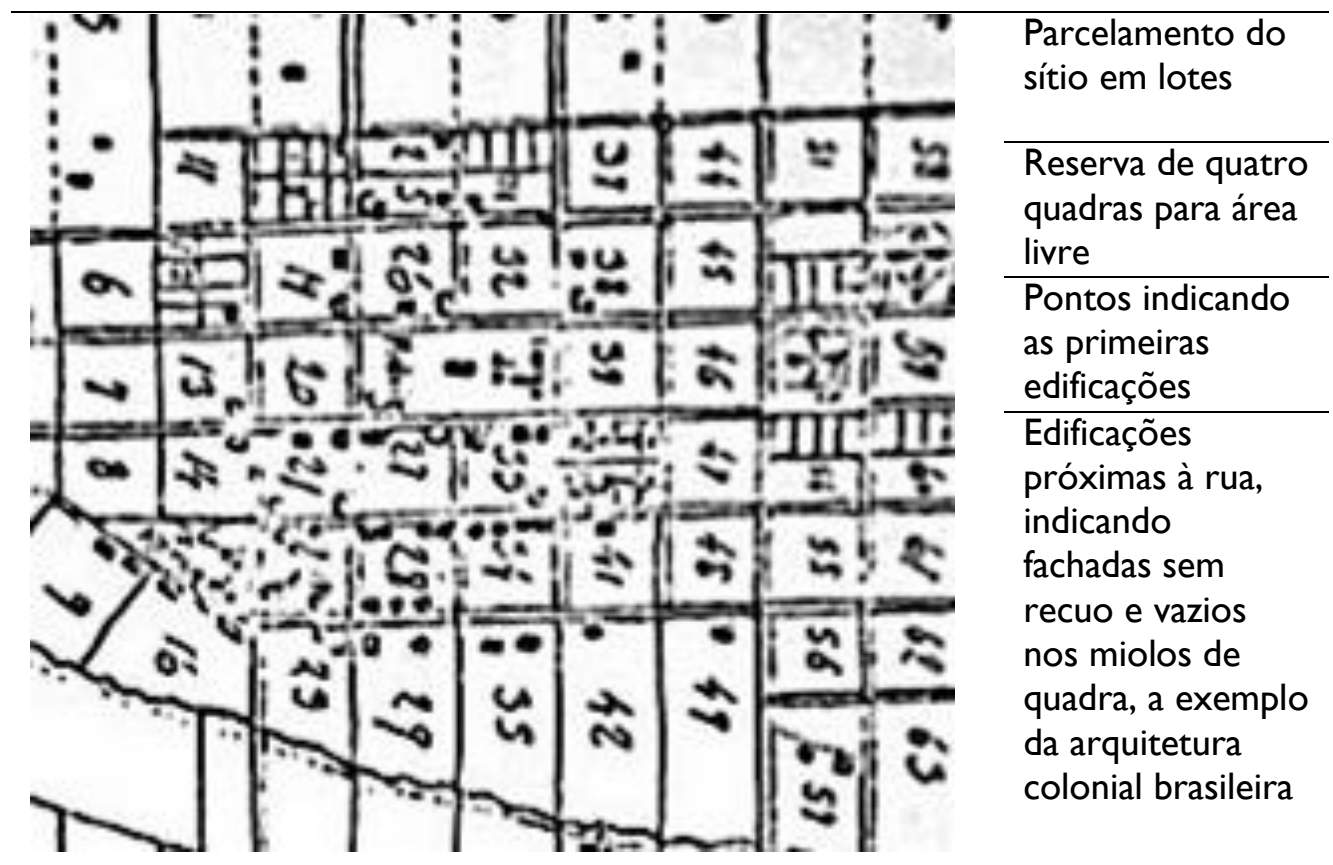

Figura 13 Detalhe de traçado avançado de Ugolini com indicação da área reservada às praças e subdivisão dos primeiros lotes urbanos.

O impacto da instalação da ferrovia, a partir de 1913 impulsiona o desenvolvimento da cidade e reflete em mudanças significativas na configuração urbana. Mesmo com os benefícios trazidos pela industrialização e a transformação da vida urbana da população, não foram feitos investimentos em infraestrutura. (TEODÓZIO, 2008)

Nas décadas de 30 e 40, mudanças urbanas significativas aconteceram, entre elas o início da verticalização em 1938 com a inauguração do edifício Caramuru, com 5 andares, localizado na Praça Rui Barbosa. 
Com a demanda de crescimento da cidade em função de suas atividades econômicas, a partir de 1945 começou a discutir-se a necessidade de um plano regulador para a cidade. Em 1948 São José do Rio Preto tinha 5648 edifícios na zona urbana, sendo que destes $75 \%$ tinham ligações de água e apenas $28 \%$ estavam ligados à rede coletora de esgoto. (ARANTES,....). Ao final da década de 40 , tornava-se evidente a necessidade de planejamento urbano que atendesse à expansão da malha urbana e também à demanda de ampliação da rede de abastecimento de água e captação de esgoto. (TEODÓZIO, 2008).
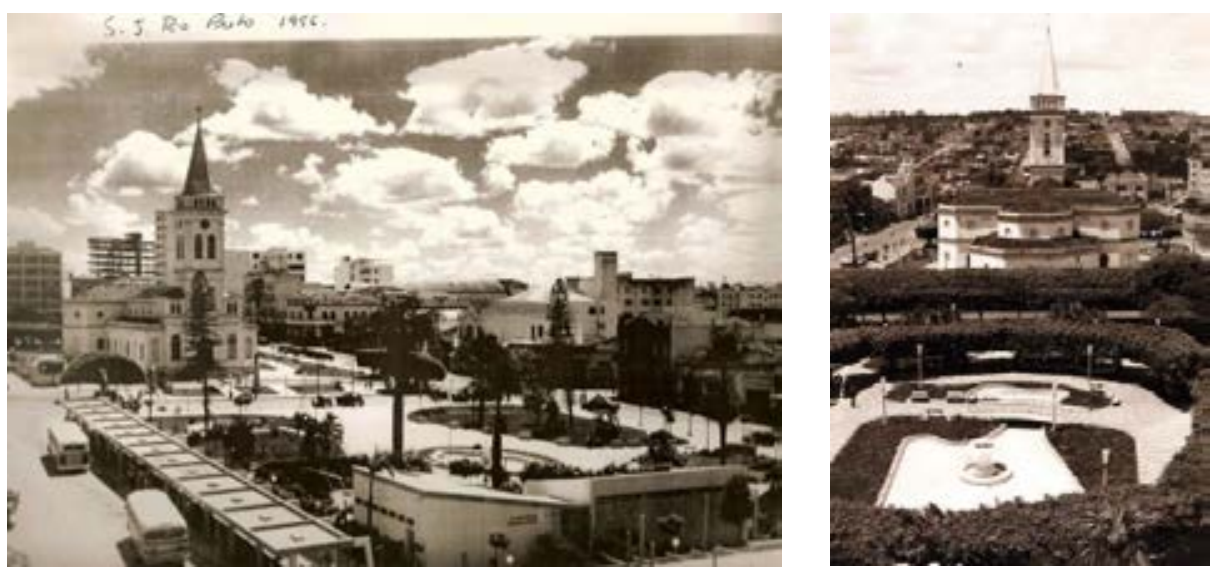

Figura 14 Antiga Catedral, vista a partir da Praça Dom José Marcondes, 1956 Figura 15 Praça Rui Barbosa na década de 50

A primeira reforma feita na Praça Rui Barbosa, na década de 50, alterou seu desenho original transformando a antiga fonte com chafariz em um espelho d'água, a pavimentação foi substituída por novos desenhos e materiais e a vegetação renovada com novas espécies arbóreas. Estas 
reformas refletiam o desenvolvimento urbano e a necessidade de adequação a novos usos e apropriações. (LODI, 2009).

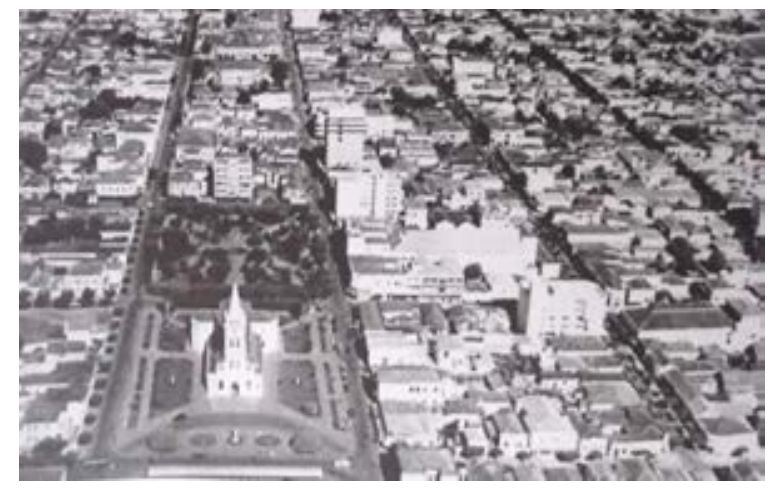

Figura 16 - Foto aérea do centro em que se identifica a distância menor entre as ruas Voluntárias de São Paulo e Bernardino de Campos, onde Luis Saia imaginou haver sido planejada uma avenida central.

Foi neste cenário que se apresentou o segundo momento importante na configuração urbana de São José do Rio Preto. A necessidade de ampliação da infraestrutura como redes de água e esgoto e elaboração de um código de obras motivou, em 1952, a contratação do arquiteto Luis Saia para a realização de um plano urbanístico para Rio Preto. Saia propôs uma solução que fazia referência à planta cadastral de Ugolino Ugolini em 1895, cuja malha ortogonal apresentava quadras mais estreitas entre as ruas Voluntárias de São Paulo e Bernardino de Campos. No entendimento de Saia, esta característica dava a impressão de uma avenida central, organizada por praças e espaços abertos. (TEODÓZIO, 2008). Para solucionar o problema do trânsito na área central, Saia propôs a ampliação das calçadas sobre o recuo do térreo dos edifícios em três metros do alinhamento frontal do lote, nas quadras circundadas pelas ruas Bernardino 
de Campos, Siqueira Campos, Voluntários de São Paulo e Marechal Deodoro. No entanto, poucos edifícios foram assim construídos. (TEODÓZIO, 2008). Mesmo com o apoio da imprensa e a opinião pública em defesa do Plano de Saia, este não foi aprovado pelo legislativo.
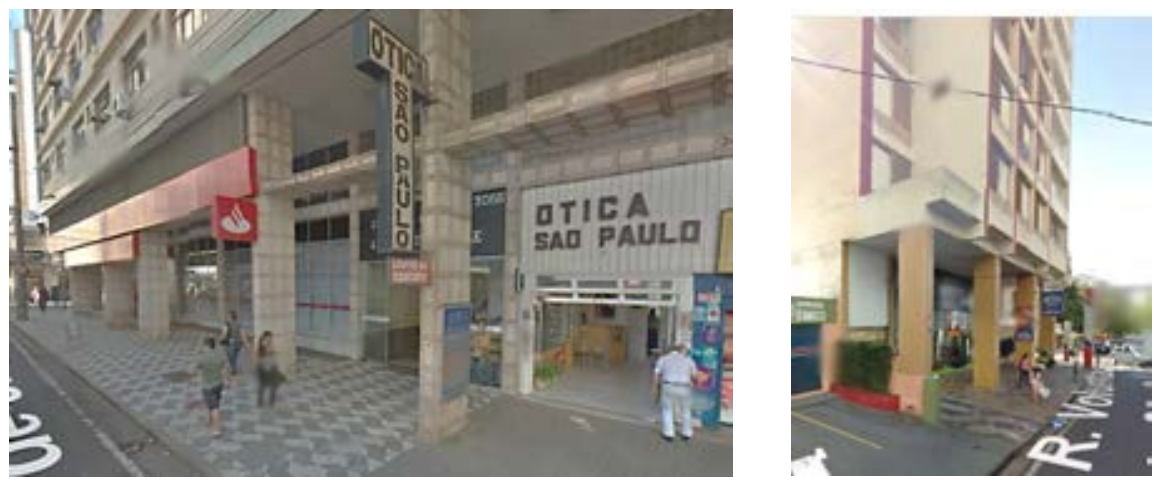

Figura 17 - Edifícios construídos com recuo de três metros e ampliação das calçadas conforme proposta de Luís Saia.

Andrade, em artigo sobre o arquiteto, destaca dois aspectos relevantes nas concepções teóricas do urbanismo de Saia. Por um lado sua atuação na área de preservação do patrimônio arquitetônico leva-o a formular propostas para o restauro de centros históricos. Por outro lado, defende a necessidade do planejamento urbano considerar as dimensões ambientais do sítio, seus aspectos geográficos, topográficos entre outros, conferindo um caráter regional ao estudo das cidades. 

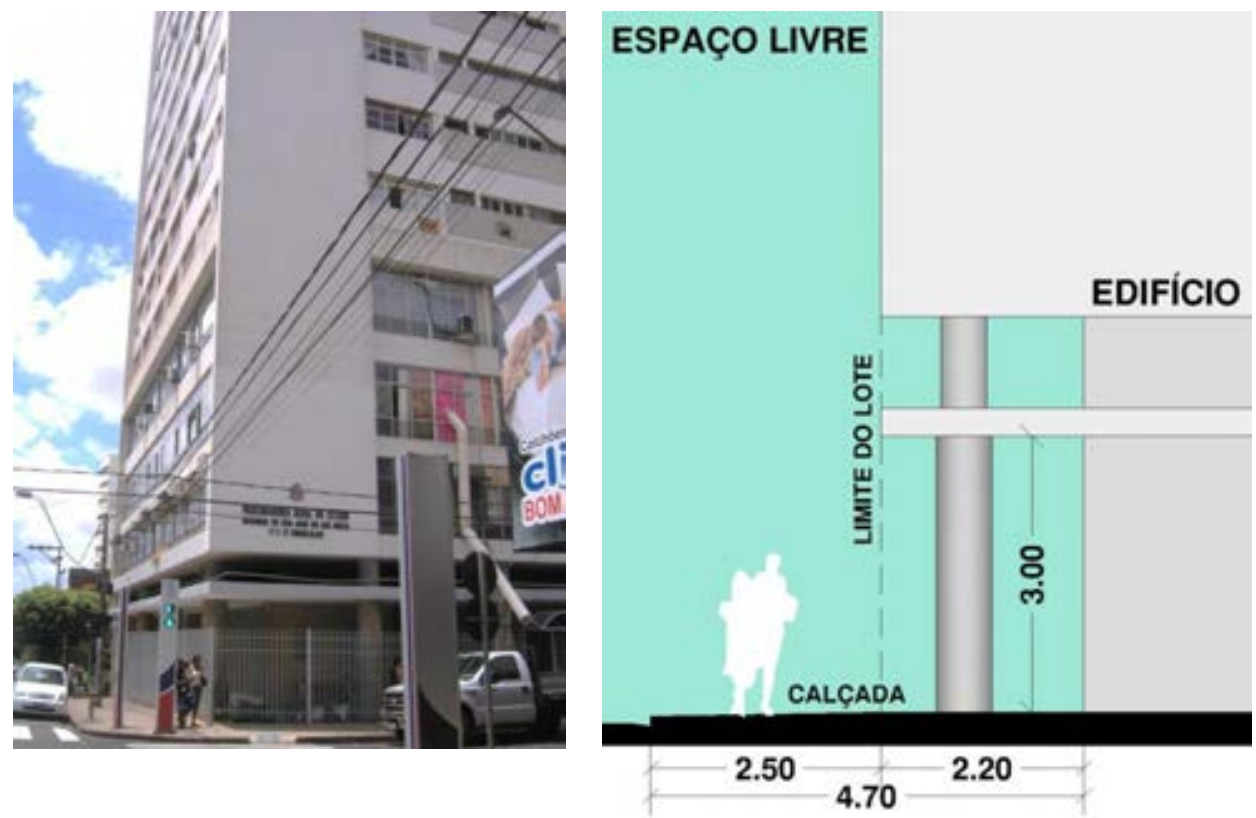

Figura 18 Edifício construído baseado nos preceitos do Plano Saia, em que o recuo do piso térreo favorece o passeio público com a ampliação do espaço livre, a calçada. $\mathrm{Na}$ foto observa-se o fechamento deste recuo com gradil, intervenção posterior.

O primeiro plano urbanístico para São José do Rio Preto só foi aprovado em 1958, com a elaboração da $\mathrm{I}^{\mathrm{a}}$ Lei de Zoneamento, elaborada elo arquiteto e urbanista Heitor José Eiras Garcia. A Lei № 535 de 1958 criou o zoneamento e regulamentou usos, ocupação do solo e volumes das edificações, subdividindo a superfície urbana em 7 zonas e 2 núcleos. 


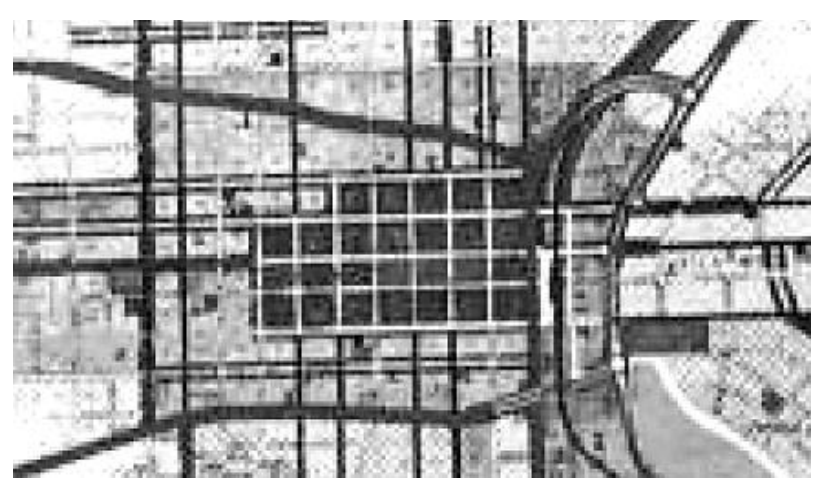

Figura 19 - Recorte do mapa da Lei de zoneamento mostrando a classificação da zona comercial (quadras em cinza escuro). 'Fonte: TEODÓZIO, 2008

Localizada na área central da cidade, a zona comercial ${ }^{5}$ possuía alta densidade e alta taxa de ocupação ( $80 \%$ para a edificação principal e $10 \%$ para as dependências), com gabarito de 10 pavimentos e índice de aproveitamento 6, sem restrições de recuos e dimensões mínimas de lote, apenas a testada mínima de 10 metros. TEODÓZIO (2008)

"Eiras Garcia apontou que uma das maiores falhas do planejamento de Rio Preto era a falta de espaços livres e indicou, na lei de zoneamento, a construção de grandes praças e parques públicos, jamais construídos de forma a atender $\circ$ projeto original. Em defesa do plano, ○ urbanista frisou que a cidade só tinha $1 \%$ de seu perímetro urbano transformado em área verde, o que

5 As categorias de uso permitidas na zona comercial eram habitações, apartamentos, atividades profissionais domiciliares, pensões, hotéis, templos, ambulatórios e clínicas, instituições culturais ou associações, escolas e anexos, edifícios públicos, casas de diversões, clubes (sede), comércio, comércio local, instituições de assistência social, lavanderias, estabelecimentos de acondicionamentos de bebidas e leite, manufatura, escritórios. 
significava 3,60 metros quadrados por habitante, sustentando que era 'uma situação alarmante que deveria ser sanada de imediato, pois quanto mais muito tempo decorrer, mais difícil seria remediar o mal'." TEODÓZIO, 2008

$\mathrm{Na}$ década de 70, a busca por um plano para solucionar os problemas causados pelo trânsito no centro da cidade resultou em um planejamento viário, elaborado pelos arquitetos Milton Farias de Assis Junior ${ }^{6}$ e José Carlos Lima Bueno ${ }^{7}$ (então Coordenador especial de Planejamento e Obras da Prefeitura Municipal e Secretário Municipal de Planejamento a partir de 1979). Configura-se assim o terceiro momento em que as diretrizes de urbanismo resultaram em alterações na área central. Foram implantados os primeiros corredores viários da cidade e transformado o centro comercial em área pedestrianizada, por meio do Plano de Sistema Viário Urbano (PSVU). Os calçadões restringiram o uso do transporte individual no centro da cidade e foram construídos no quadrilátero de 12 quadras integradas às praças Rui Barbosa, Praça da Igreja de São José e Dom José Marcondes.

6 Arquiteto e urbanista, mestre pela EESC USP.

7 Arquiteto e urbanista , mestre pela EESC USP e doutor pela FAU USP 

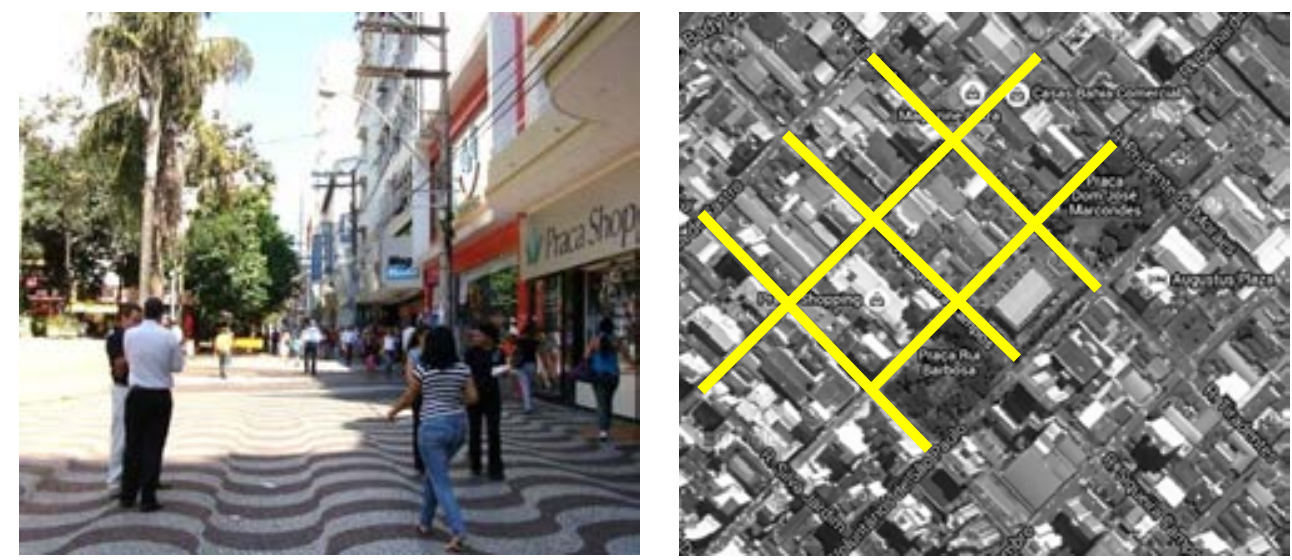

Figura 20 - Calçadão na rua Bernardino de Campos, Foto Débora Zórnio Figura 2I - Mapa com indicação de área pedestrianizada

Ainda na década de 70 , foi construído o terminal de ônibus urbano e a Praça Cívica, esta projetada pelos arquitetos Jamil José Kfouri e Mythes Baffi, ambos espaços contíguos ao centro comercial da cidade. Em 1979, estes mesmos profissionais são contratados para realizar $\bigcirc$ Plano Paisagístico Municipal de Rio Preto, elaborando o Plano de Áreas Verdes, compreendendo projetos e medidas de proteção ambiental do rio Preto e do córrego Piedade. Em 1982 realizam o projeto do Parque Setorial e do Parque da Represa.

Em 1990, por meio do Plano Diretor, estabelece-se uma política de desenvolvimento urbano em que era exigido por lei a proteção ao meio ambiente (TEODÓZIO, 2008). Em 1992 são aprovadas junto ao plano diretor, sete leis complementares com impacto na morfologia urbana, especialmente, a Lei 5135 - Lei de Zoneamento, uso e ocupação do solo, Lei 5 I 34 com as diretrizes do sistema viário e a Lei 5138, de parcelamento 
e uso do solo urbano. O plano diretor institui o Conselho de Planejamento do Plano Diretor (CPDD), órgão consultivo para assuntos relacionados ao plano diretor.

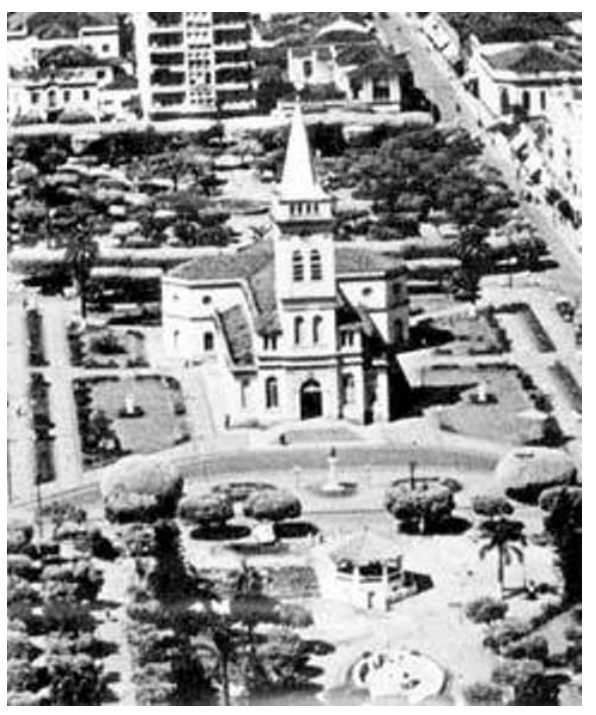

Figura 22 Praças Dom José Marcondes, Igreja de São Losé e Praça Rui Barbosa ao fundo, década de 50

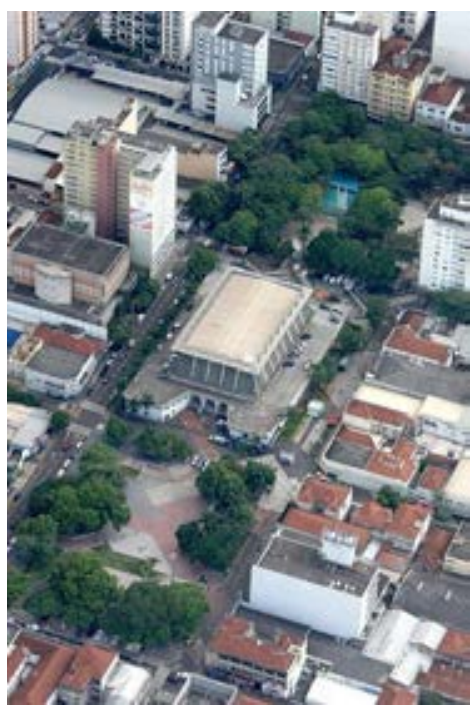

Figura $23 \bigcirc$ mesmo local na década de 90, com sua configuração atual.

A Lei de Zoneamento 5135 definiu as categorias de uso, subdividindo o município em 14 zonas e determinou as condições gerais para uso dos lotes e índices urbanísticos. A área objeto deste estudo é classificada como zona 5, correspondendo à zona de recuperação urbana com densidade decrescente: "atual centro urbano, cuja densidade já é excessiva e onde há diversidade muito grande de usos, o que o configura como uma zona de qualidade urbana em vias de degradação e que, por isso, deve ser recuperada".

${ }^{8}$ lei $n^{\circ} 5135$ de 24 de dezembro de 1992. 
Segundo o artigo 13 da mesma lei, esta área também deve ter tratamento como zona $10^{9}$.

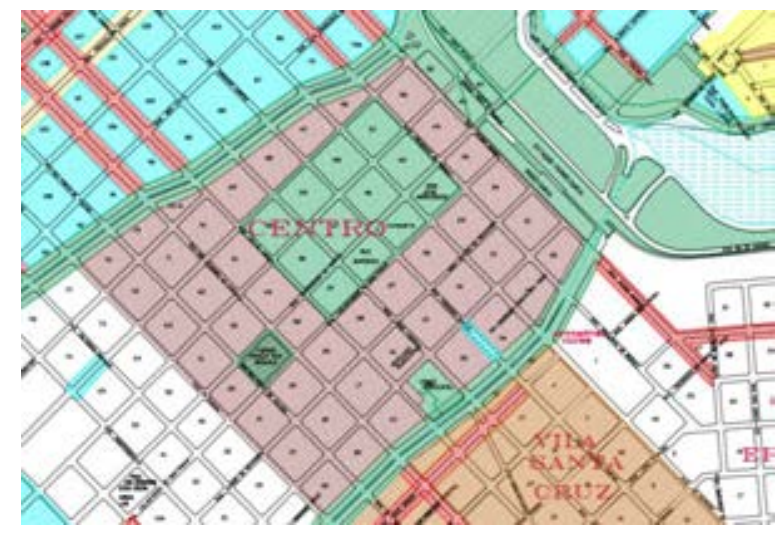

zona 5

zona de recuperação urbana com densidade decrescente

\section{zona 10}

zonas especiais, regulamentação especial a critério de SEMPLAN e C.P.D.D.

Figura 24 - Recorte da área central no mapa de parcelamento, uso e ocupação do solo, parte da Lei de Zoneamento $N^{\circ} 5135$ de 1992.

A partir de 2002, através da Lei 9.708 de 25/07/02 e criação do Plano de Desenvolvimento Urbano (PDDU), consolidou-se um sistema com vias radiais, anel interbairros e anel rodoviário urbanístico da cidade onde toda expansão urbana obedece às diretrizes viárias estabelecidas nestas leis. (CE, 20I3).

O quarto momento na evolução da concepção urbanística da cidade ocorreu em 2006, com a criação do Plano Diretor de Desenvolvimento Sustentável, documento orientador da política de desenvolvimento urbano,

\footnotetext{
${ }^{9}$ Artigo 13 - Terão tratamento como Z-10 as seguintes zonas: 2 - Área de Pedestres do Centro Urbano -"Calçadão": compreendendo toda a área interna ao mini-anel de contorno da área de pedestres, com início no cruzamento da Rua Prudente de Moraes com a Rua Voluntários de São Paulo, seguindo por esta até a Rua Silva Jardim e desta até a Rua Coronel Spínola de Castro, seguindo por esta até a Rua Prudente de Moraes e desta até a Rua Voluntários de São Paulo.
} 
que tem como princípios "o cumprimento das funções sociais da cidade e da propriedade urbana, a sustentabilidade urbana e a gestão democrática e participativa". 10

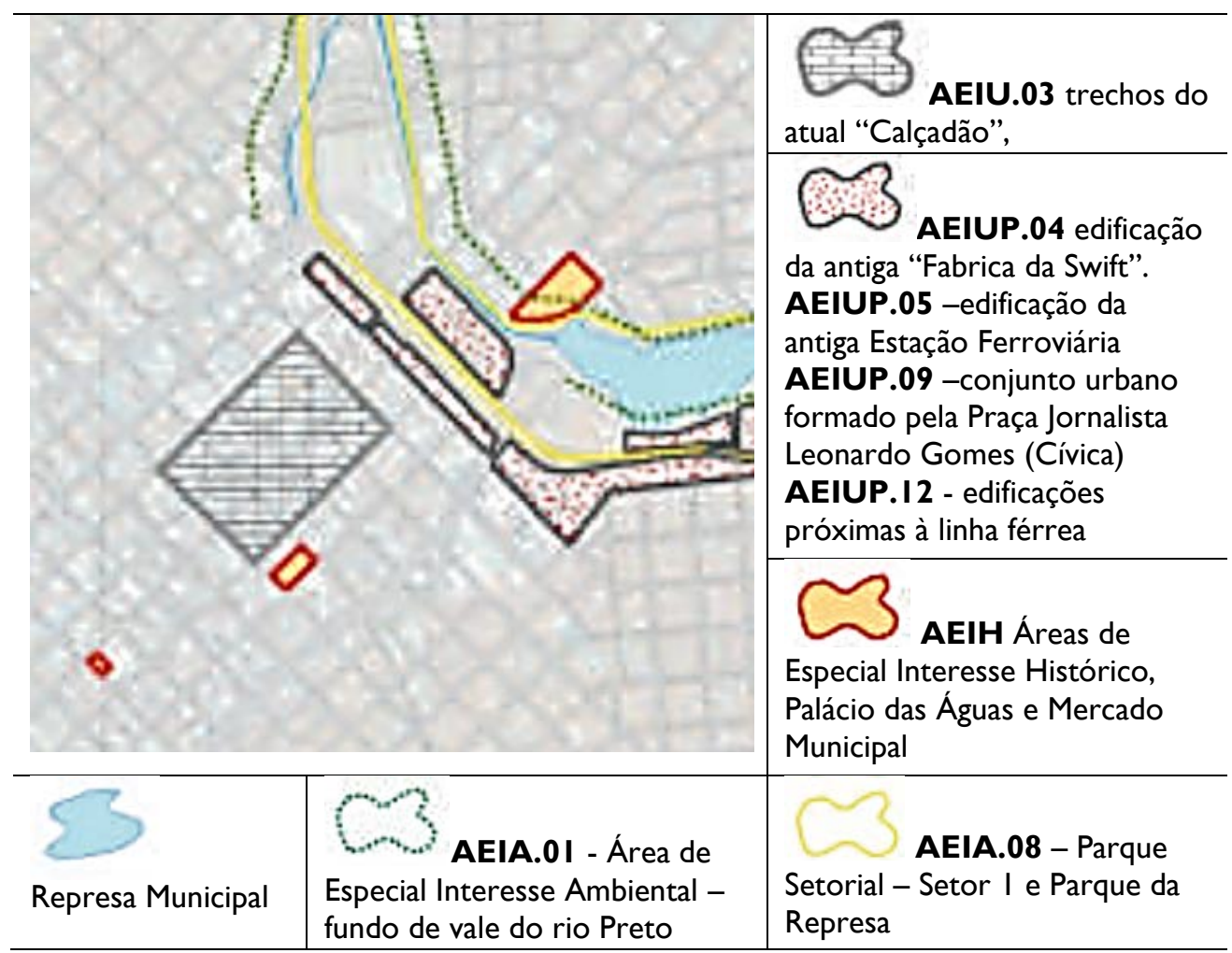

Figura 25 Recorte da área central no mapa do Plano Diretor de Desenvolvimento Sustentável de 2006 e indicação de Áreas de Especial Interesse (AEI).

Para a lei complementar do Plano Diretor de Desenvolvimento Sustentável (PDDS) são considerados componentes do patrimônio ambiental todos os recursos naturais e culturais classificados e relacionados como Áreas de

${ }^{10}$ LEI COMPLEMENTAR N²24 DE 06 DE OUTUBRO DE 2006. Dispõe sobre o Plano Diretor de Desenvolvimento Sustentável de São José do Rio Preto 
Especial Interesse Histórico, Turístico e Ambiental, visando diminuir o impacto negativo do processo de urbanização; conservar e promover o valor histórico/arquitetônico; controlar o uso e a ocupação de áreas consideradas ambientalmente frágeis, evitando situações geradoras de erosão, de assoreamento ou de inundação e recuperar áreas degradadas, entre outras diretrizes.

Importante observar que a área central da cidade corresponde a uma Área de Especial Interesse Urbanístico (AEIU-03"') considerada aquela que "demande tratamento urbanístico próprio por sua expressão ou ainda por ser área degradada, necessitando a sua reestruturação urbana" ${ }^{\prime 2}$ e está relacionada com outras várias áreas assim classificadas. As Áreas de Especial Interesse são classificadas de acordo com as suas características e as de principal interesse deste trabalho são as área de especial interesse Ambiental ${ }^{13}$, Urbanístico e Histórico e para Utilização Pública.

\subsection{3 Áreas verdes e espaços públicos na cidade}

A história da cidade, anteriormente apresentada, narra os principais fatos que deram origem aos critérios para definição de áreas verdes e espaços livres na cidade. Como observado, em todos os momentos, esta

\footnotetext{
"AEIU.03 - trata-se de trechos do atual "Calçadão", assim como os lotes que fazem frente a estas vias, para sua consolidação como via preferencial de pedestre.

12 LEI COMPLEMENTAR Nº 224 DE 06 DE OUTUBRO DE 2006. Dispõe sobre o Plano Diretor de Desenvolvimento Sustentável de São José do Rio Preto.

13 'constituindo-se naquela necessária à manutenção ou recuperação de recursos naturais e paisagísticos, bem como a que apresente riscos à segurança e ao assentamento humano', segundo Plano Diretor de Desenvolvimento Sustentável.
} 
necessidade foi subjugada em detrimento de outros interesses que definiam a dinâmica de configuração da cidade. A atual morfologia das praças e parques urbanos é resultado de uma história de decisões políticoadministrativas que muitas vezes subestimou o benefício potencial para a cidade contido na ampliação e valorização de seus espaços livres.
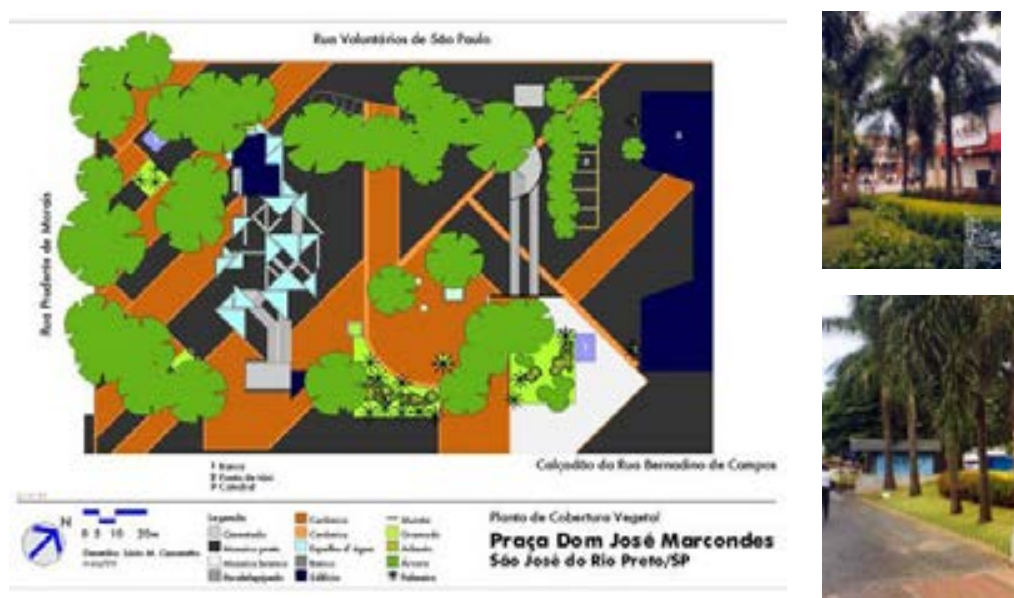

Figura 26 Praça Dom José Marcondes, projeto de 1993 do arquiteto Milton Faria Assis Junior em registro do Quapá realizado em 1999. Fonte: Quapá - Banco de Dados

O município de São José do Rio Preto, segundo a Conjuntura Ambiental de 2007, possui um total de 836 hectares de área verde urbana, correspondendo a $7,24 \%$ de sua área total. Neste levantamento, foram considerados os fundos de vale, as praças arborizadas, parques urbanos, rotatórias e canteiros centrais permeáveis das avenidas e não estão computadas as copas das árvores de calçadas, pois estas são impermeabilizadas. $O$ índice de área verde por habitante é de $20.1 \mathrm{Im}^{2} / \mathrm{hab}$., No entanto, vale a pena observar que a extensão territorial da malha 
urbana é desproporcional a seu adensamento. A aplicação deste critério para a leitura de toda a cidade não expressa necessariamente a quantidade e qualidade dos espaços livres públicos da cidade. Apenas por meio da somatória de toda a área urbanizada, com seus imensos vazios urbanos, pode-se chegar ao índice apresentado pelo documento citado. Além disso, este índice, teoricamente atribuído à ONU (Organização das Nações Unidas), que parece nem saber do que se trata, é questionado pelos pesquisadores exatamente por não expressar a realidade da maioria das cidades,

São José do Rio Preto possui espaços livres projetados pelo trabalho de diferentes arquitetos e paisagistas, como o Parque Setorial, a Praça Dom José Marcondes e o calçadão da Bernardino, conforme levantamento sistemático feito pelo grupo de pesquisa da FAU-USP Quapá - Quadro do Paisagismo no Brasil.
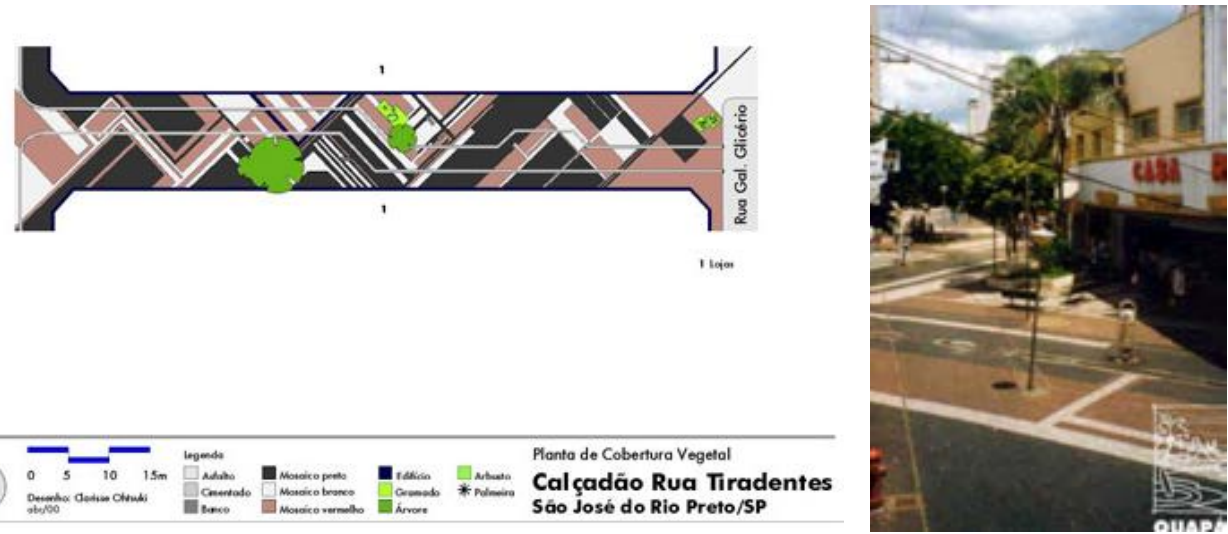

Figura 27 Calçadão da Tiradentes, projeto realizado em 198I pelo arquiteto Francisco Carlos Verroni. Fonte: Quapá - Banco de Dados. 
Outro fato importante refere-se às condições de infraestrutura dos principais equipamentos públicos de lazer e área verde da cidade. $O$ Bosque Municipal e a Cidade da Criança encontram-se sem reformas, adequações e manutenção, assim como as principais praças da cidade.
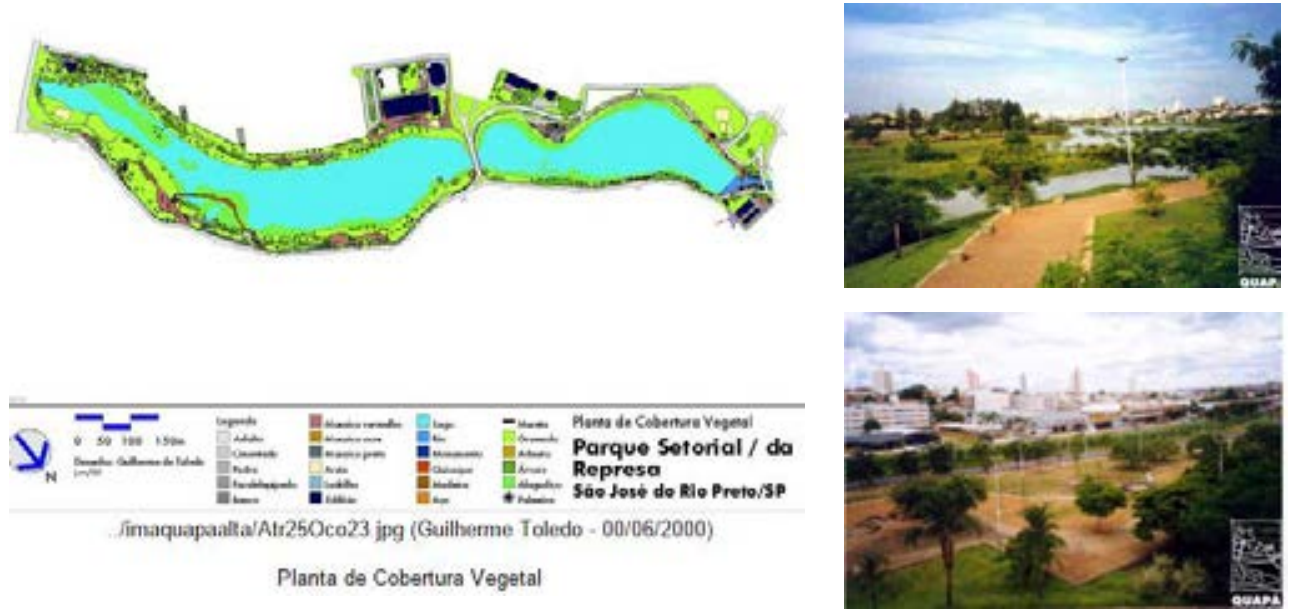

Figura 28 Parque Setorial Lagos I e 2, projeto dos arquitetos Jamil Kfouri e Mirthes Baffi. Fonte: Quapá - Banco de dados.

O projeto e implantação do Parque Setorial também demonstram a pouca importância dos gestores públicos quando o assunto é a construção da paisagem e criação de áreas verdes. No Lagol foi recém-construída uma via de acesso no sentido centro-bairro, em área inicialmente destinada à atividades de educação ambiental como um setor do projeto original dos arquitetos Jamil Kfouri e Mirttes Baffi. Há poucos anos foi construído o Hospital da Mulher em área também de estoque do Parque Setorial, sentido córrego Piedade. As áreas de fundo de vale do rio Preto são fundamentais para a drenagem e para o equilíbrio ambiental urbano e, 
mesmo sem uso, são o estoque para a efetivação futura do projeto do parque e área potencial para arborização urbana e preservação dos $70 \%$ de área livre de edificação exigido pelo Plano Diretor de Desenvolvimento Sustentável ${ }^{14}$.

Cidades em todo o mundo discutem a preservação e ampliação de seus espaços verdes. Comunidades, poder público e iniciativa privada buscam um entendimento para atender uma necessidade comum, criar melhores condições de vida humana nas cidades. São José do Rio Preto parece estar na contramão da história. A última decisão da Prefeitura em transformar a Praça Cívica em Terminal Urbano parece confirmar uma tendência da cidade na desvalorização de seus espaços livres e áreas verdes.

\subsubsection{Delimitação da área objeto de estudo}

Ao estudar a cidade de Barcelona, Romero (200I) afirma que, a partir da análise de suas praças pode-se estruturar a história e entender as mudanças na formação arquitetônica da cidade. Com este entendimento, foram escolhidos exemplos de espaços livres na área central de São José do Rio Preto, os quais serão descritos como modelos de referência para o estudo a que este trabalho se propõe.

\footnotetext{
14 AEIA.08 - Parque Setorial - Setor I e Parque da Represa: trata-se de área propícia à micro drenagem urbana e ao saneamento ambiental como um todo, destinada à formação de parque. Nesta área são permitidos usos conservacionistas e deve-se procurar manter a taxa de permeabilidade do solo igual ou superior a $70 \%$ (setenta por cento).
} 
O bairro Centro corresponde à região administrativa $n^{\circ}$ I com uma população total de 6211 habitantes, e uma característica importante no perfil dos moradores: $53.1 \%$ correspondem a adultos acima de 45 anos, dentre eles $31,2 \%$ são idosos, acima de 60 anos $^{15}$.

A área deste estudo corresponde às praças Rui Barbosa e Dom José Marcondes, Catedral de São José e parte do calçadão da Rua Bernardino de Campos correspondendo a uma área total de $29700 \mathrm{~m}^{2}$. Para efeito deste estudo, será considerado o entorno imediato da área, delimitado pelas ruas Silva Jardim, Gal. Osório, Pedro Amaral e XV de Novembro.

O espaço é caracterizado com áreas extensas de piso para circulação de pedestres, pequenas áreas de estar sombreadas e não, arborização diversificada com o predomínio de espécies nativas, uma lâmina dágua com chafariz, mobiliário urbano e tipos de pisos de diferentes épocas, equipamentos urbanos como sanitário público, palco, pontos de táxi, bancas de revistas, quiosques e tendas comerciais. Uma grande colcha de retalhos, em cujo entorno configura-se uma arquitetura de diversas épocas, dimensões, formas e linguagens. Um cenário de caos urbano, resultante das inúmeras transformações, reformas e adaptações, cheio de vitalidade durante o horário comercial, onde moradores e trabalhadores utilizam o local para as mais diversas finalidades. À noite, aos domingos e feriados, o espaço transforma-se em um lugar ermo, ocupado apenas por moradores do bairro e de rua, na principal e maior área verde do centro e arredores.

\footnotetext{
${ }^{15}$ Indicadores demográficos da Conjuntura Econômica 2012
} 


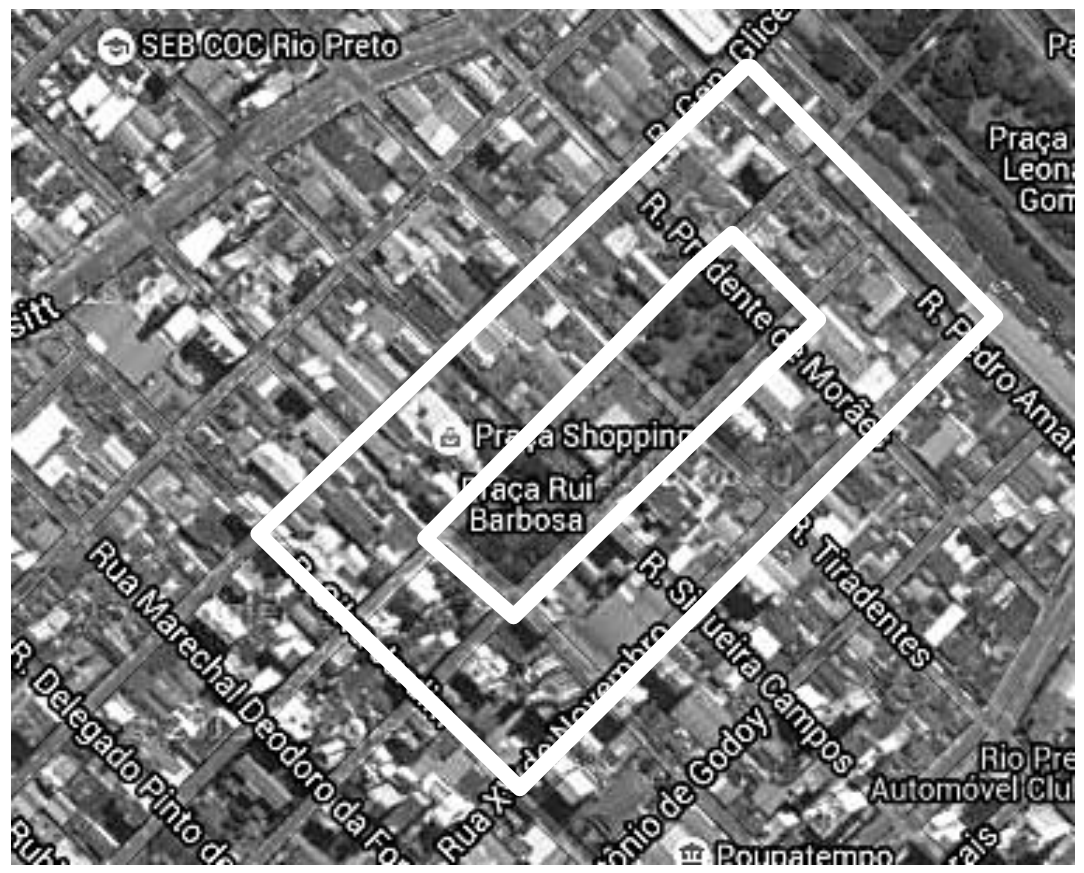

Figura 29 Localização, delimitação e informação de vias do objeto de estudo. Fonte Google Earth.

\subsection{PLANEJAMENTO DA PESQUISA DE CAMPO}

A realização da pesquisa de campo foi feita baseada no referencial teórico e definição de metodologia apresentados anteriormente, que possibilitaram o cumprimento dos objetivos do trabalho. A primeira etapa da pesquisa correspondeu ao levantamento físico do local, resultando na identificação atualizada e criação de uma base cartográfica, composta por mapas de uso do solo, topografia, verticalização, gabarito e áreas verdes.

Foi elaborado um roteiro para a pesquisa de campo e um questionário para aplicação junto aos usuários com o objetivo de obter informações sobre a percepção térmica e de conforto do pedestre. A coleta de dados de campo 
foi planejada para ocorrer no período climático característico da região com temperaturas altas. Este levantamento deu-se nos dias 17 e 18 de marco de 2013 simultaneamente nos três pontos pré-selecionados às $8 \mathrm{hs} 00,10 \mathrm{hs} 00,12 \mathrm{hs} 00,14 \mathrm{hs} 00$, e $16 \mathrm{hs} 00$.

\subsection{Instrumentos de medição}

O desenvolvimento da pesquisa de campo contou com dois principais instrumentos, os equipamentos para levantamento de dados e os questionários para entrevistas com os usuários.

\subsection{I.I Equipamentos}

Para as medições microclimáticas, foram utilizados 3 sensores HOBO para aferir temperatura e umidade do ar, que foram instalados com proteção solar e afixados em tripés metálicos a $1.20 \mathrm{~m}$ de distância do solo, A manipulação para obtenção digital das informações coletadas pelos hobos foi feita pelo Laboratório de Conforto Ambiental do IAU, que gerou as planilhas em Excel para posterior análise. Nos mesmos tripés, também foram instalados 3 termômetros para medir a temperatura de globo. Estes dados foram coletados pela equipe da pesquisa e anotados em planilha a cada duas horas junto às entrevistas realizadas com os usuários do local. 


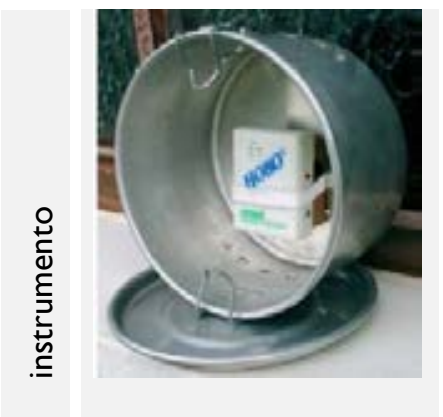

sensor hobo protegido contra radiação

temperatura do ar e umidade relativa

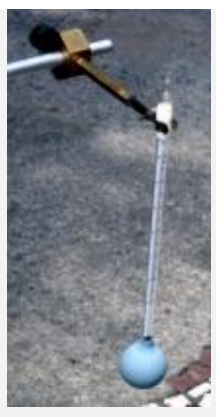

Termômetro de globo

temperatura de globo

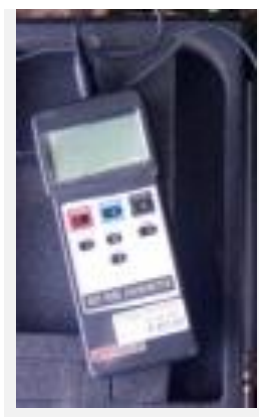

anemômetro

velocidade dos ventos

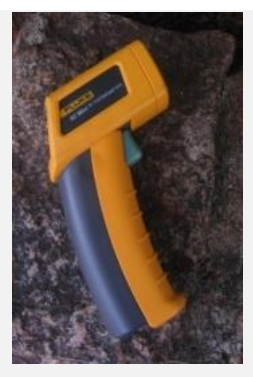

termômetro de Infraver-melho

temperatura de superfícies

Foram utilizados um anemômetro digital para medir a velocidade do vento e um termômetro de infravermelho para levantamento da temperatura das superfícies, medidas aferidas e anotadas a cada duas horas para os diferentes tipos de recobrimento do solo próximo aos pontos de medição. A aferição simultânea nos três pontos exigiu que uma pessoa da equipe pudesse se movimentar para este levantamento, que foi aferido e registrado nas planilhas a cada duas horas.

\subsubsection{Formulários}

Durante as medições foram realizadas as entrevistas com os usuários que transitam nas proximidades de cada ponto, com a finalidade de verificar 0 perfil do usuário e sua sensação térmica e percepção ambiental. $O$ número total de entrevistas foi distribuído nos 2 dias de coleta totalizando 83 
formulários em cinco horários das medições. Estes questionários foram elaborados baseados no modelo proposto por Katzchner (1997) e foram vinculados à planilha de medição junto às variáveis ambientais aferidas no mesmo horário das entrevistas. Os modelos são apresentados anexo.

\subsection{I.3 Localização e caracterização dos pontos amostrais}

O levantamento foi realizado em três pontos e como referência para os dados amostrais foram considerados dados de monitoramento automático da Estação Meteorológica da Cetesb, localizada no bairro Eldorado, zona Noroeste da cidade. Nesta estação, o equipamento utilizado é um termo higrômetro, instalado a uma altura de $4,5 \mathrm{~m}$ de distância do solo cujo objetivo é avaliar a qualidade do ar urbano. Os dados foram obtidos através da internet.

As áreas de abrangência dos pontos de medição foram caracterizadas por elementos espaciais de cobertura do solo e edificações e/ou planos verticais próximos aos pontos. A partir dessas informações, foram calculadas taxas de cobertura e impermeabilização do solo em porcentagem da área total.

Os três pontos de medição possuem características diferentes quanto morfologia, recobrimento do solo, verticalização e vegetação. A definição dos pontos foi subsidiada pela sobreposição e análise desta base cartográfica e resultou na escolha de locais com as seguintes características: 
I) uma área livre de edificação, local de permanência, sombreada por vegetação e entorno verticalizado (Ponto I - Praça Rui Barbosa );

2) uma área livre de edificação e vegetação, local de passagem e permanência - área seca com entorno de vegetação (Ponto 2 - Praça Dom José Marcondes) e

3) uma área livre com entorno construído e pouca vegetação, local de passagem (Ponto 3 - Calçadão da Bernardino).

\section{Ponto I - Praça Rui Barbosa}

Localizado na Praça Rui Barbosa, em área sombreada por árvores e próximo à cobertura do ponto de táxi. A pavimentação do local é feita em paralelepípedo. $\bigcirc$ entorno caracteriza-se pela verticalização de seus edifícios e grandes áreas sombreadas por espécies arbóreas de grande porte.

\section{Ponto 2 - Praça Dom José Marcondes}

Localizado na área "seca” da Praça Dom José Marcondes, em área livre de vegetação e distante do entorno edificado. O terreno é pavimento com bloco de concreto intertravado e livre da sombra de árvores e edificações.

\section{Ponto 3 - Calçadão da Bernardino}

Localizado na rua Bernardino de Campos, em área de uso exclusivo de pedestres, entre a Catedral de São José e a edificação comercial fronteiriça em pavimento térreo. A área é pavimentada com diferentes tipos de piso, tais como paralelepípedo, concreto, pedra portuguesa, entre outros. 
O levantamento de dados em campo foi realizado nos dias 17 e $18 / 03 / 2013$. Foram instalados sensores automáticos para leitura manual de temperatura e umidade do ar. Ao mesmo tempo, foram aferidos manualmente dados de temperatura de superfície e velocidade do vento. Além disso, foram realizadas entrevistas para avaliação da percepção térmica e compreensão da relação entre os dados microclimáticos coletados e o comportamento do usuário. As leituras manuais ocorreram a cada 2 horas, às $8,10,12$, 14, e 16hs, totalizando nos dois dias e nos três pontos 30 registros de dados. Em cada ponto foram feitas em média I,4 entrevistas por ponto a cada hora de registro, totalizando um universo de 83 entrevistas realizadas no período. 


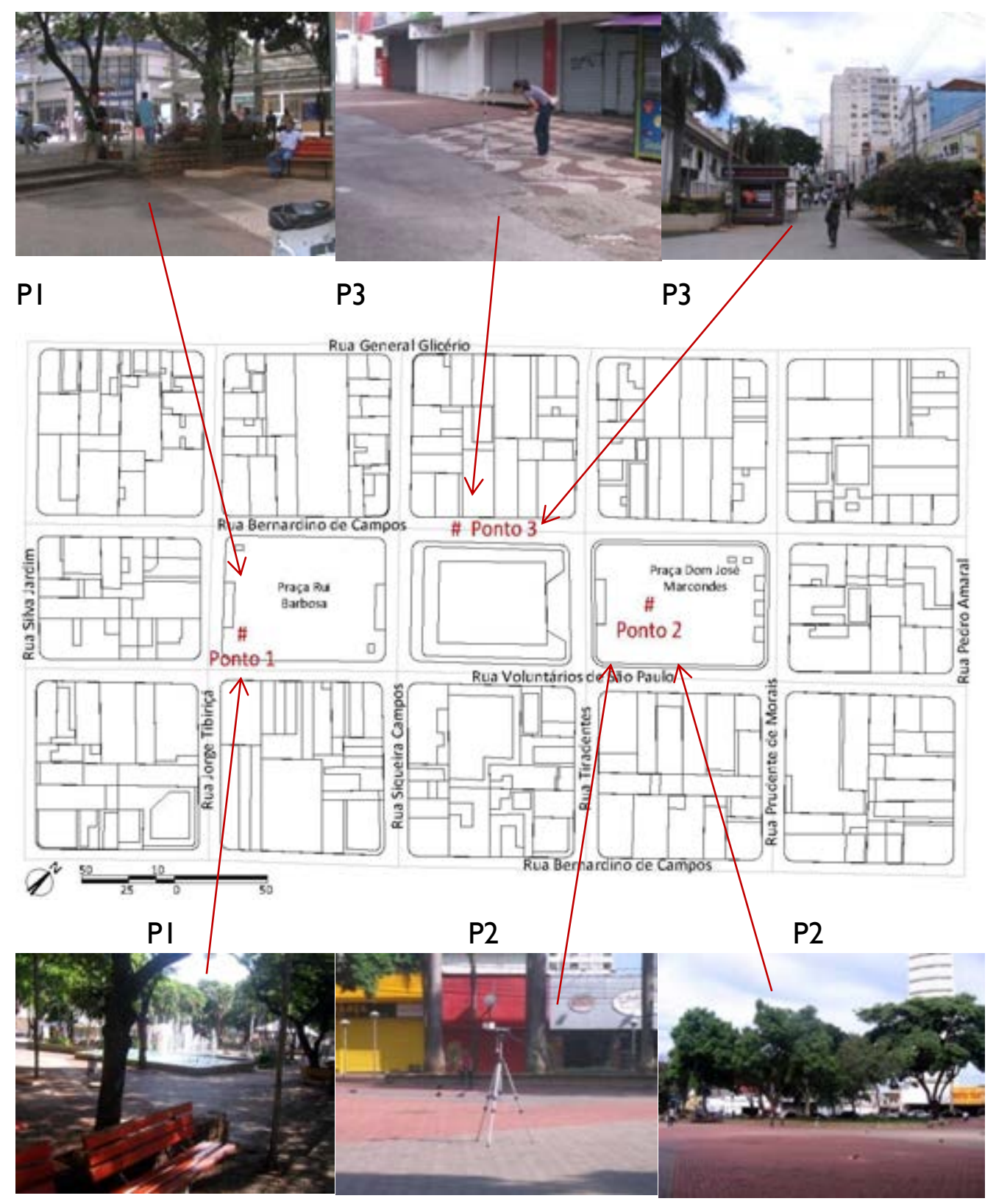

Figura 30 - Mapa de localização dos pontos amostrais e entorno imediato com gabarito edificado 


\section{CARACTERIZAÇÃO DO OBJETO DE ESTUDO E PESQUISA DE CAMPO}

\section{I CARACTERIZAÇÃO MORFOLÓGICA}

Com o objetivo de subsidiar a seleção dos pontos amostrais e auxiliar na compreensão da morfologia urbana local, foi elaborado o levantamento "in loco" da área e seu entorno imediato, de aproximadamente 100 metros. Este levantamento gerou 6 mapas temáticos, elaborados em AutoCad a partir de mapa cadastral da Prefeitura, a saber: topografia, uso do solo, altura das edificações, gabarito, recobrimento do solo e vegetação, a seguir apresentados.

\section{I.I.I Topografia}

O objeto de estudo está situado em um ponto privilegiado do sítio, em sua topografia. Localiza-se no alto do espigão, a 490 do nível do mar, entre os córregos Borá e Canela, hoje canalizados sob as avenidas Badi Bassit e Alberto Andaló, respectivamente, Apresenta-se em uma extensão de aproximadamente $360 \mathrm{~m}$ em um desnível de $10.30 \mathrm{~m}$, ou seja, o terreno apresenta uma inclinação de cerca de $3 \%$, em média. $\mathrm{Na}$ área mais alta está localizada a Praça Rui Barbosa com a área mais arborizada do conjunto e na parte mais baixa a Praça Dom José Marcondes, com a catedral de São José entre as duas praças. $O$ relevo favorece a drenagem, não sendo identificado nenhum ponto crítico de alagamento. 


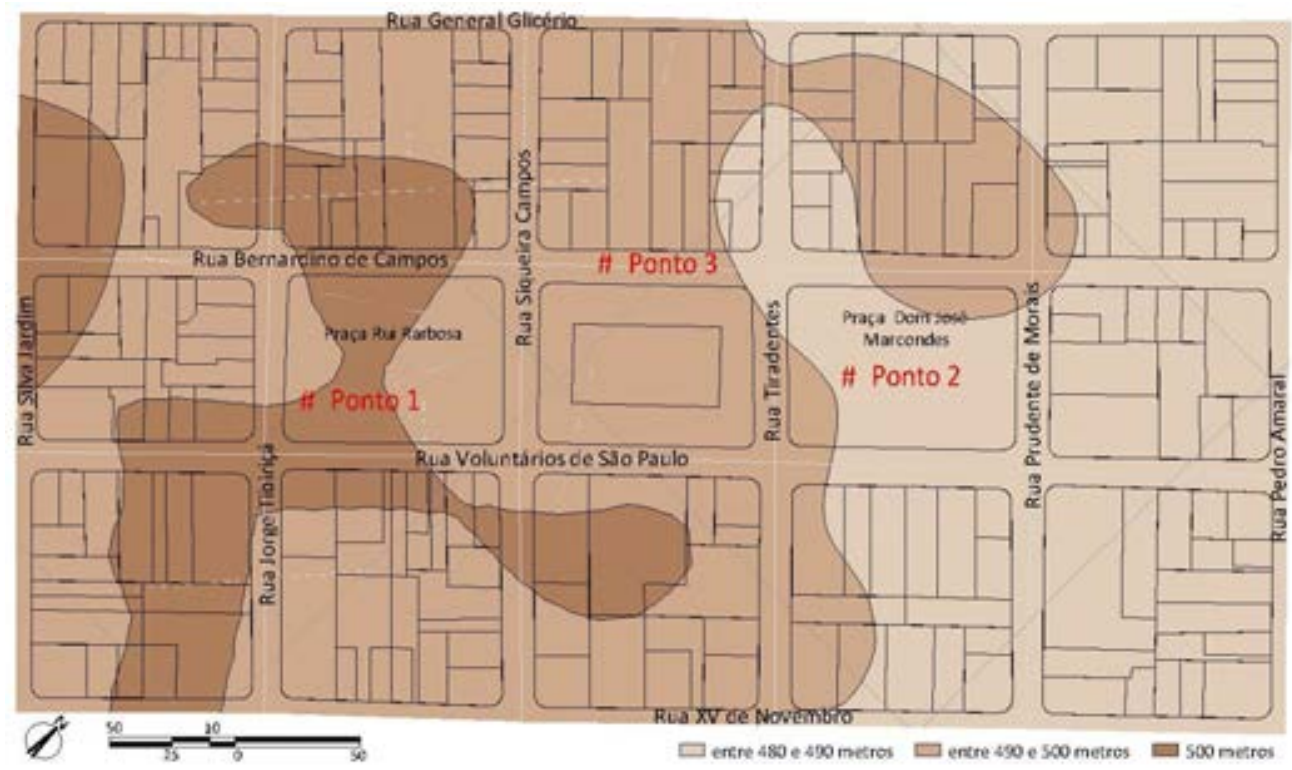

Figura 31 - Mapa de topografia, elaborado a partir de mapa cadastral da Prefeitura Municipal e análise in loco - novembro/2012

A área está orientada na direção nordeste-sudoeste, sendo assim favorecida pela direção dos ventos e pela insolação. As faces noroesteoeste, consideradas as mais críticas para a insolação no período do verão são protegidas na praça Rui Barbosa pela verticalização das edificações adjacentes. Já a praça Dom José Marcondes, fica exposta a insolação contando apenas com a proteção e sombreamento de suas espécies arbóreas. 


\subsubsection{Uso do Solo}

Foi observado uso bastante diversificado com o predomínio de ocupação comercial e serviços. Existem diversos edifícios altos residenciais e poucos terrenos vazios.

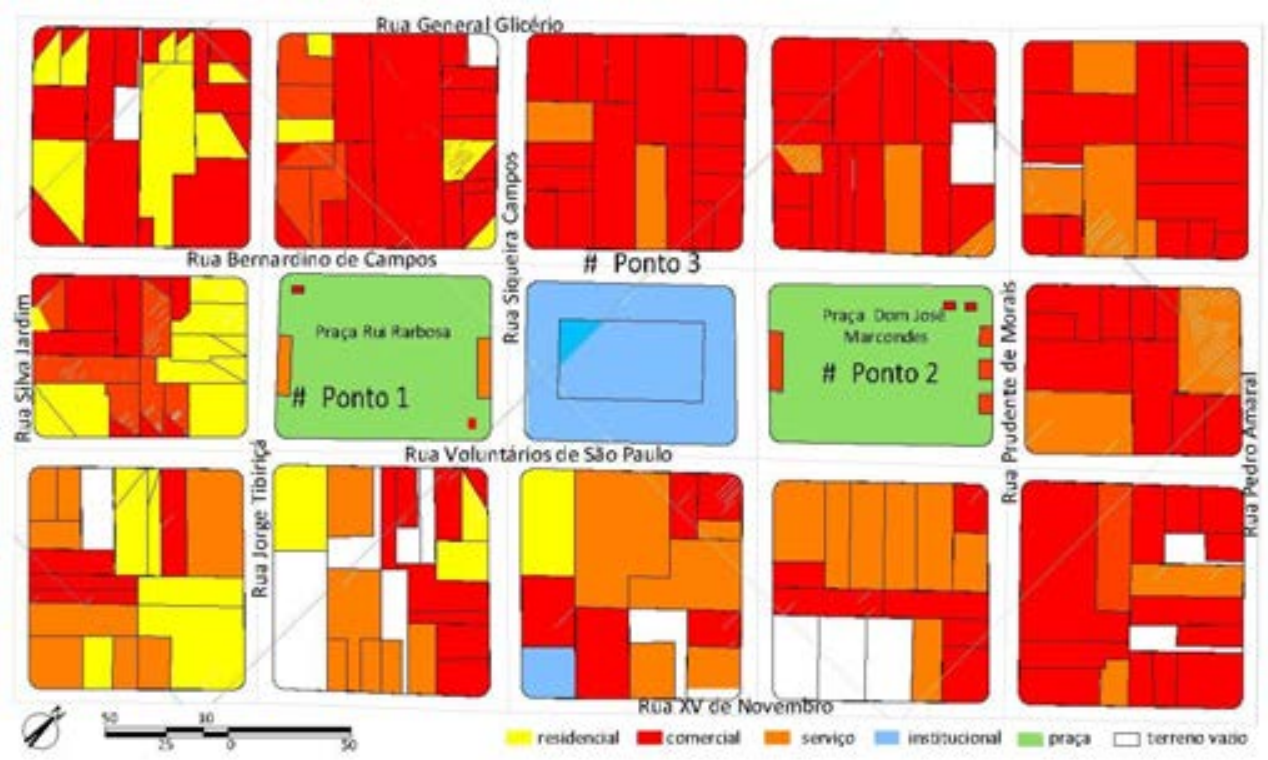

Figura 32 - Mapa de uso e ocupação do solo, elaborado a partir de mapa cadastral da Prefeitura Municipal e análise in loco - novembro/2012

Residencial: O local apresenta poucos edifícios de uso exclusivamente residencial, uso também identificado em edifícios verticalizados de uso misto, onde no térreo configura-se comércio ou serviços e acima do $3^{\circ}$ pavimento residências.

Comercial: Uso predominante na área, presente em todas as quadras do entorno, caracterizado principalmente pelo conjunto de edificações térreas ou assobradas, construídas nos séculos $\mathrm{XIX}$ e $\mathrm{XX}$ e que sofreram as mais 
diversas intervenções para adaptação de uso. Apresenta diversificação significativa com lojas, lanchonetes e bares de pequeno porte e comércio popular e também lojas “âncora”, de telefonia móvel, lotéricas e um shopping Center.

Serviço: bastante presente e distribuído em quase todo o entorno, apresenta hotéis em edifícios históricos e novos, a maior agência de correios da cidade, também instalada em edifício histórico, bancos, a ACIRP (Associação Comercial e Industrial de Rio Preto) e restaurantes, além de estacionamentos nos poucos terrenos vazios.

Institucional: O local possui apenas um edifício, a Procuradoria do Estado e dois templos religiosos, sendo a Catedral de São José o maior em ocupação da área em estudo.

\section{I.I.3 Altura das edificações}

O local apresenta grande diversidade quanto a sua verticalização. Desde edifícios térreos ou de dois pavimentos em sua forma original do século XIX até edifícios de 16 andares. Há o predomínio de edifícios de 2 pavimentos onde a maioria é de edificações térreas distribuídas em quase todas as quadras. Considera-se importante a verticalização do local, visto que em algumas quadras concentram-se edifícios de 3 a 5 andares e ainda, próximos a praça Rui Barbosa, estão os edifícios altos, com mais de 6 pavimentos. A altura das edificações é bastante diversificada, resultado em considerável rugosidade para efeitos de aproveitamento da ventilação natural e insolação. 


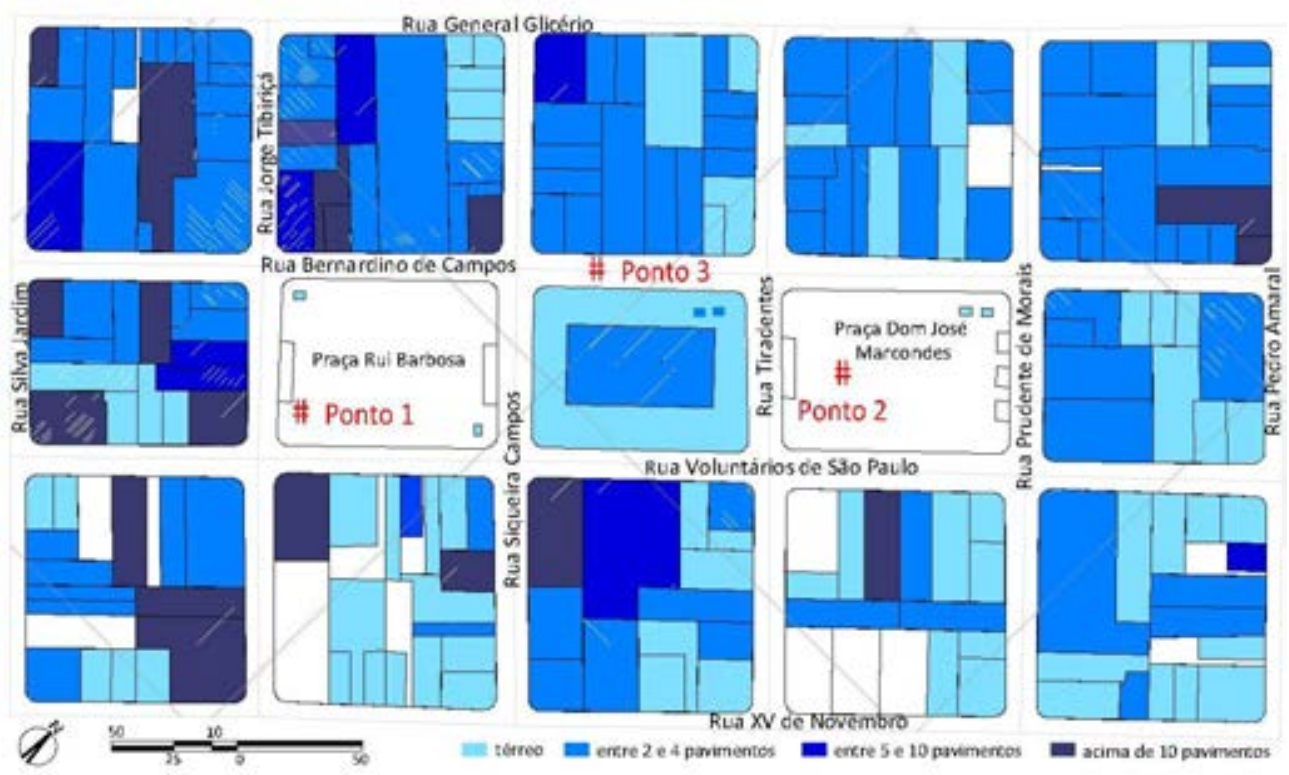

Figura 33- Mapa de altura das edificações, elaborado a partir de mapa cadastral da Prefeitura Municipal e análise in loco - novembro/2012

\section{I.I.4 Gabarito de figura fundo e espaços livres}

Neste levantamento observou-se a alta densidade da área e exiguidade de espaços livres no interior dos lotes (áreas privadas), ressaltando a importância do bom uso do espaço livre público configurado pelas ruas, calçadas e praças. 


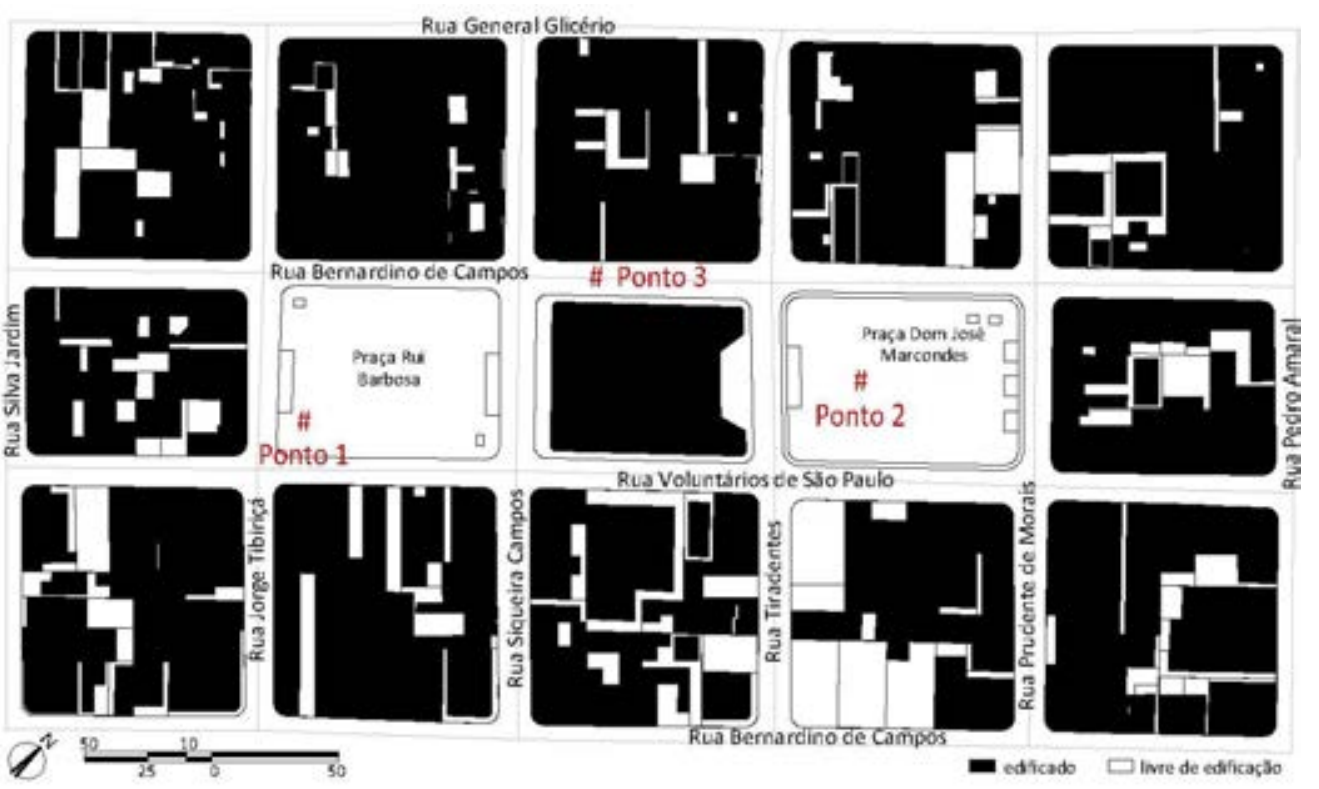

Figura 34 - Gabarito de figura/fundo, elaborado a partir de mapa cadastral da Prefeitura Municipal e análise in loco - novembro/2012 


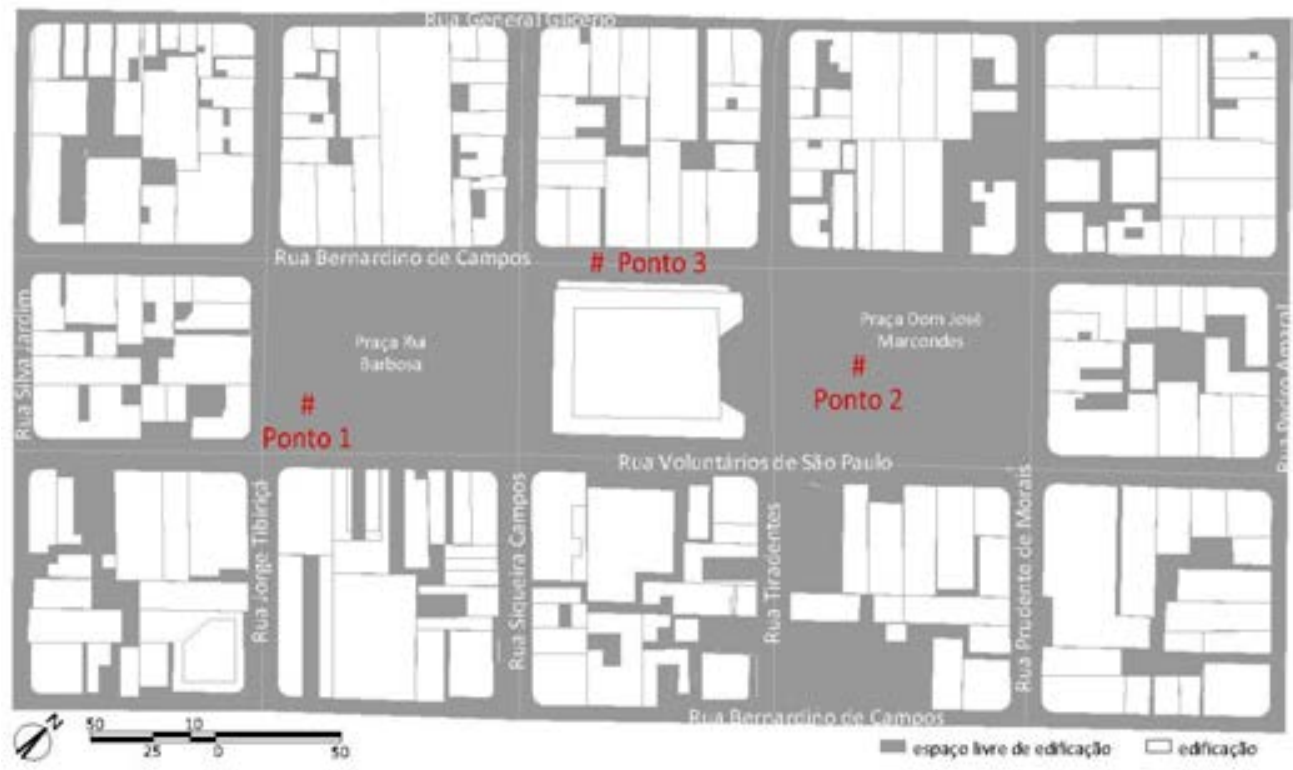

Figura 35 - Gabarito de espaços livres de edificação, elaborado a partir de mapa cadastral da Prefeitura Municipal e análise in loco - novembro/20I2

\subsubsection{Vegetação}

A área verde existente no local concentra-se nos espaços das praças Rui Barbosa e Dom José Marcondes, onde há uma grande diversidade de espécies. Observa-se o predomínio de elementos arbóreos como a sibipiruna, o ipê e o mungubá e palmeiras nativas como a areca e o jerivá. Também observa-se registro de dois exemplares de pau-brasil, 2 de pauferro, 2 tipuanas e 2 quaresmeiras, entre outros da flora nativa local. Nas trechos das ruas do calçadão, a saber ruas Siqueira Campos e Tiradentes foram plantadas espécies de grande porte, como angico e ipê, em local muito próximo às fachadas edificadas. Não há espaço para indivíduos destas 
espécies se desenvolverem, o que provavelmente irá resultar em remoções futuras.

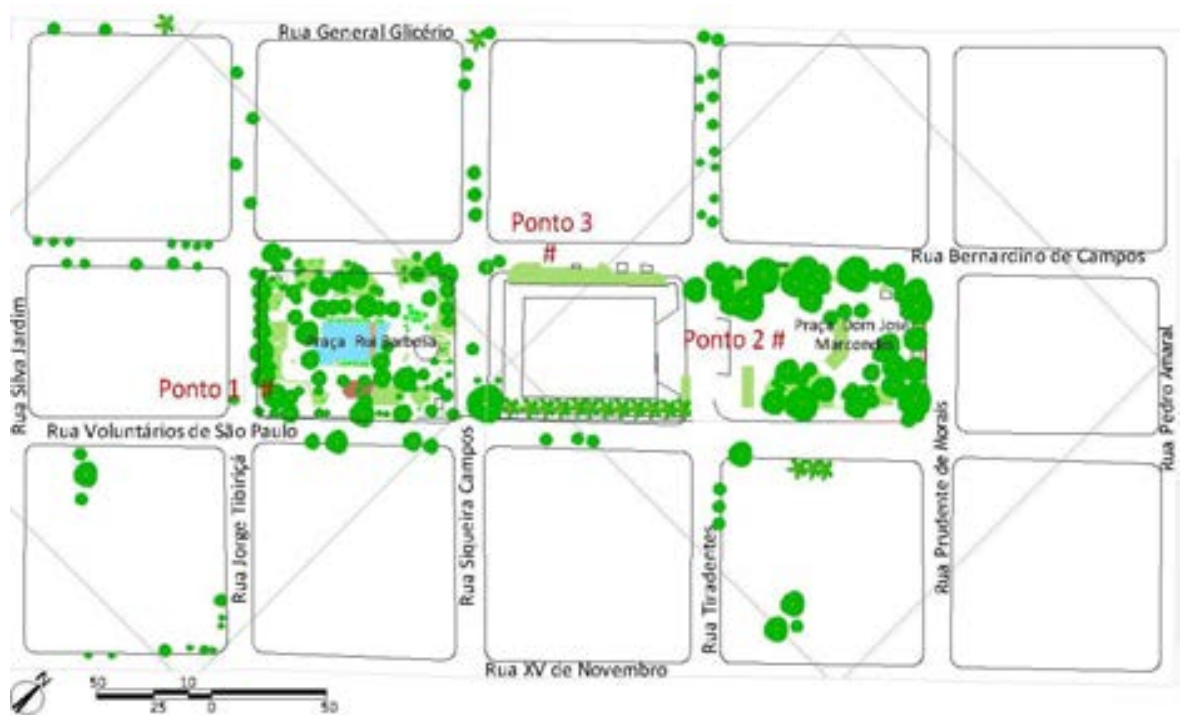

Figura 36 - Mapa de Vegetação, elaborado a partir de mapa cadastral da Prefeitura Municipal e análise in loco - novembro/2012

\section{I.I.6 Recobrimento do solo}

Existem no local algumas áreas de solo nu, sendo a maior parte ocupada com pavimentações e edificações. Todas as vias são pavimentadas, sendo a maioria recoberta por asfalto ou bloco de concreto intertravado, cujo alto albedo implica em alta emissão de calor e pouca permeabilidade. A área das praças, que originalmente possuíam amplas áreas permeáveis, foi transformada em praças pavimentadas para circulação de pessoas e instalação de pequenos comércios e serviços, como bancas de revistas, livrarias e quiosques. 
O desenho resultante do tipo de recobrimento do solo apresenta-se como um mosaico de intervenções, ocorrido durante as transformações impostas pelas necessidades funcionais e determinadas principalmente pela atividade comercial.

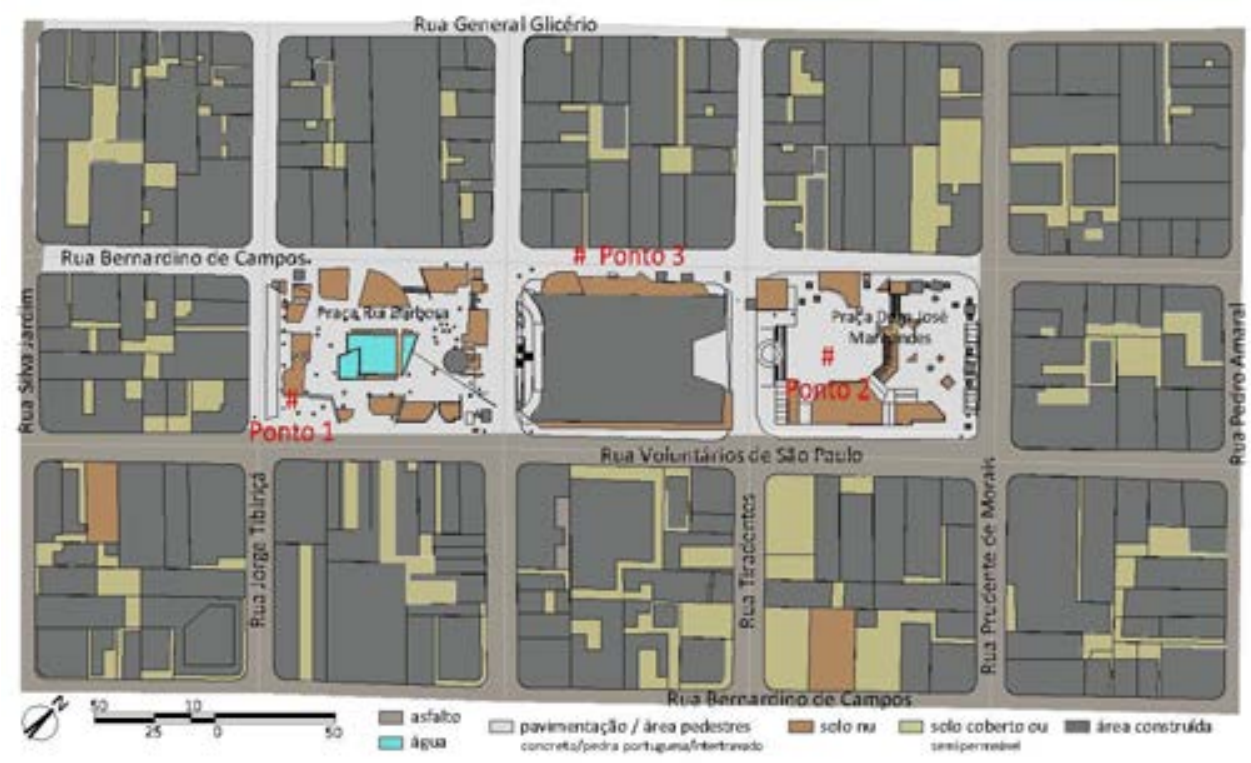

Figura 37 - Mapa de recobrimento do solo, elaborado a partir de mapa cadastral da Prefeitura Municipal e análise in loco - novembro/20I2

Inúmeras adaptações foram feitas e o tipo de pavimentação conta esta estória com precisão. Neste mapa não foi possível identificar, a área exata dos diferentes tipos de piso, já que estas delimitações são muito irregulares. Optou-se assim pela adoção do piso predominante como critério para definir as massas de revestimentos. 


\subsection{ANÁLISES}

A seguir são apresentados os resultados qualitativos e quantitativos da pesquisa. Inicialmente é apresentada a ficha bioclimática dos pontos de medição, em seguida apresenta-se a análise do microclima através dos dados coletados, gerados pelas medições de variáveis ambientais e por último são analisados os resultados das entrevistas com os usuários. 


\subsection{Morfologia dos pontos de medição}

\subsection{I.I Ficha bioclimática do ponto I}

PONTO I - PRAÇA RUI BARBOSA

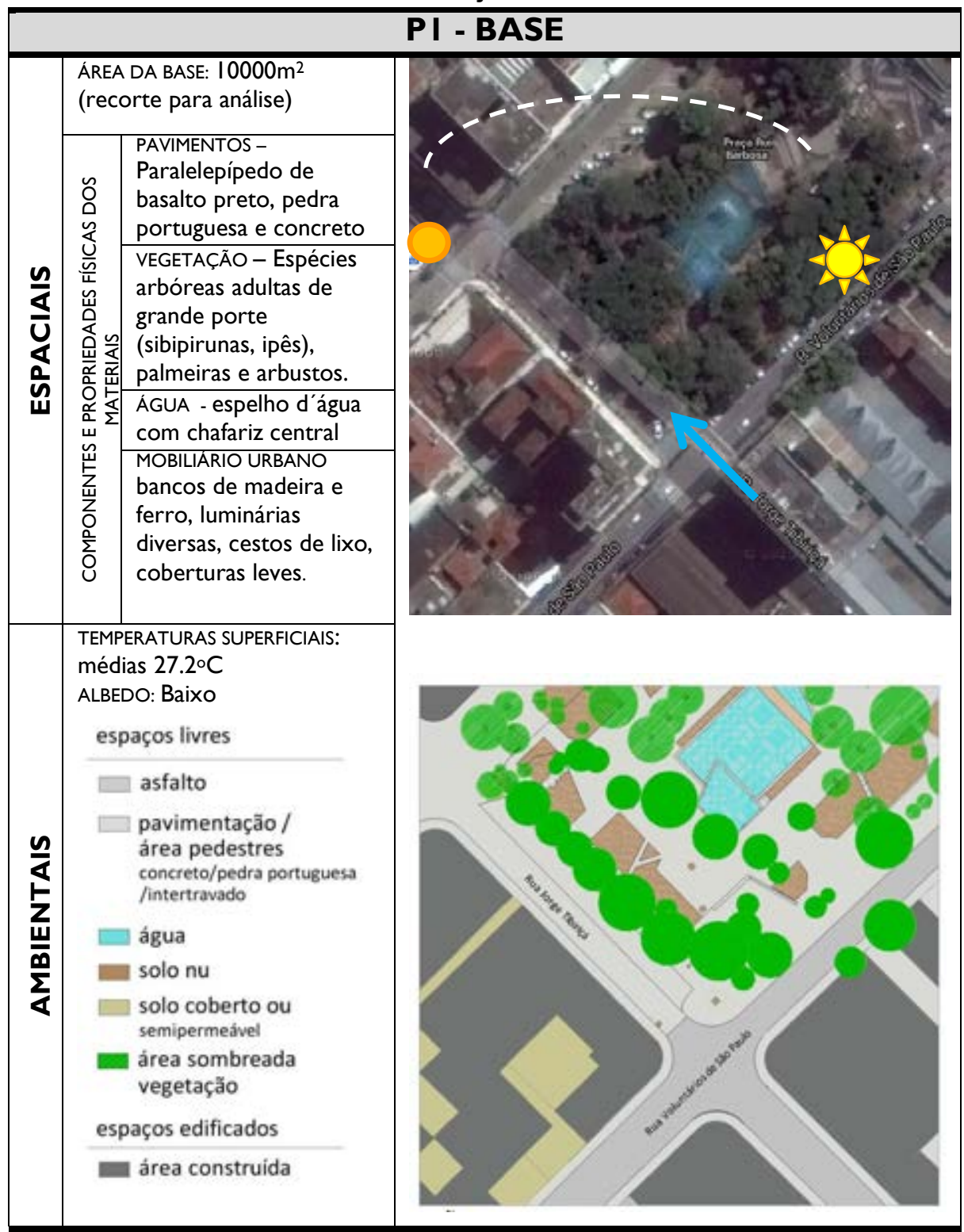




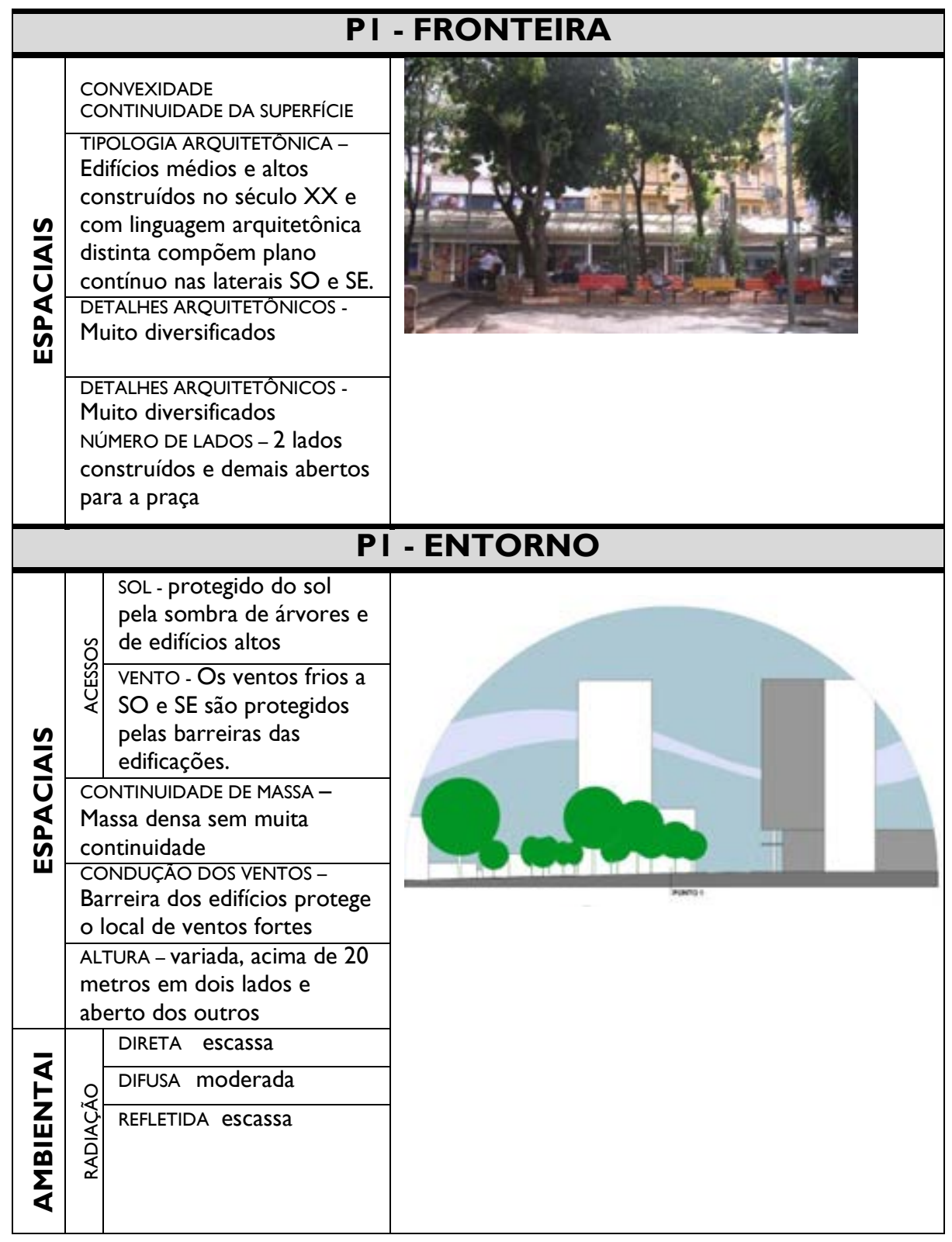




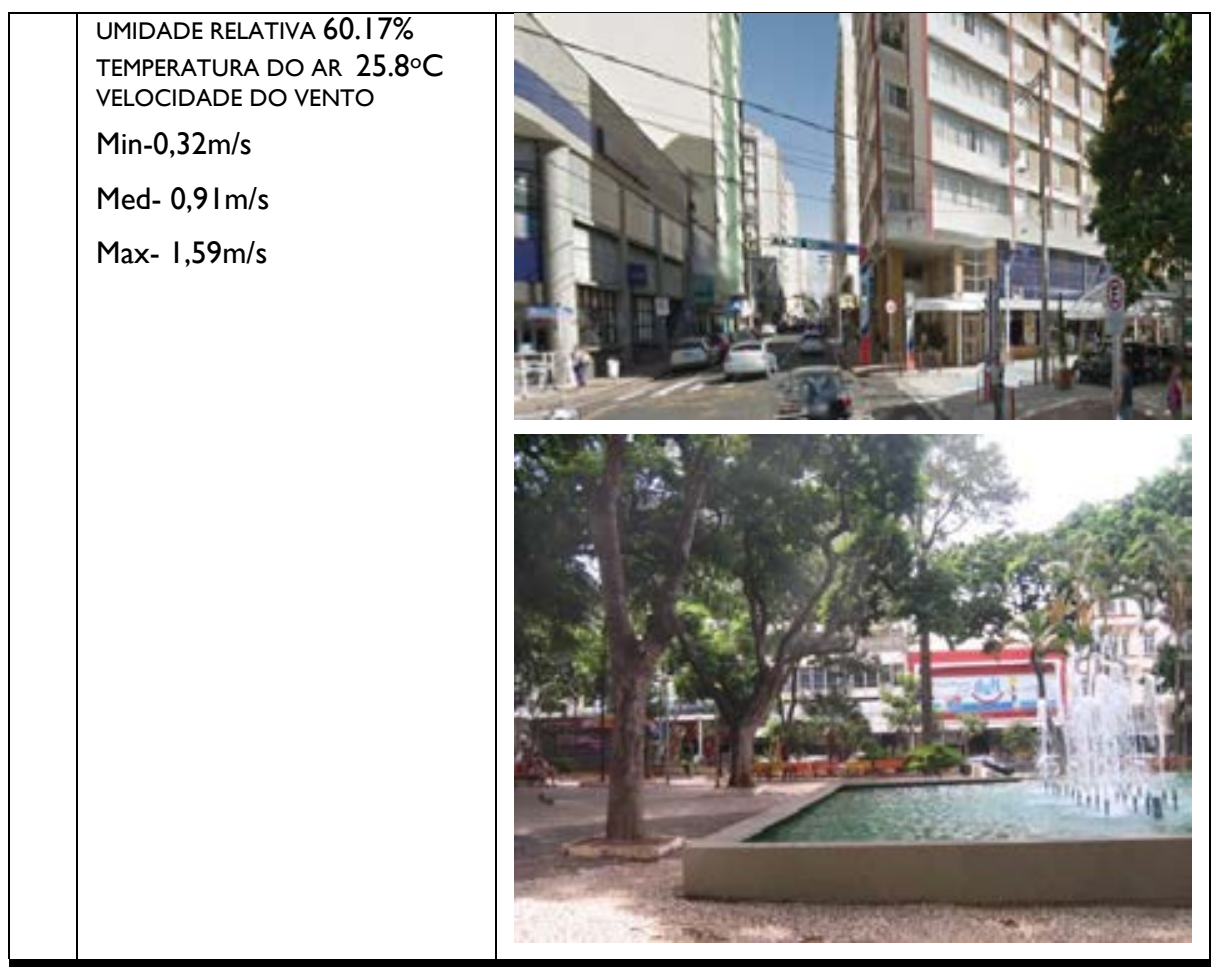




\subsubsection{Ficha bioclimática do Ponto 2}

\section{PONTO 2 - PRAÇA DOM JOSÉ MARCONDES}

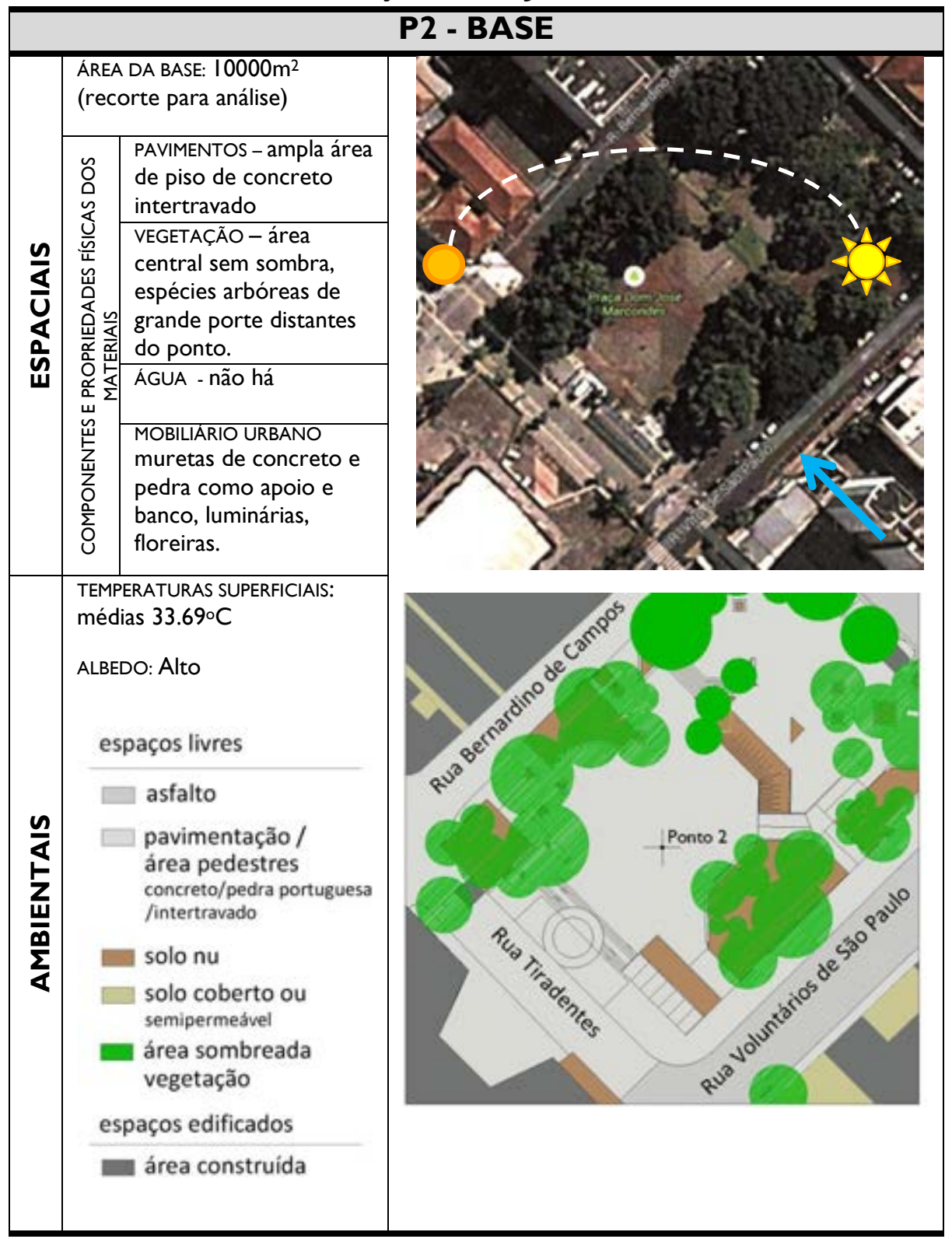




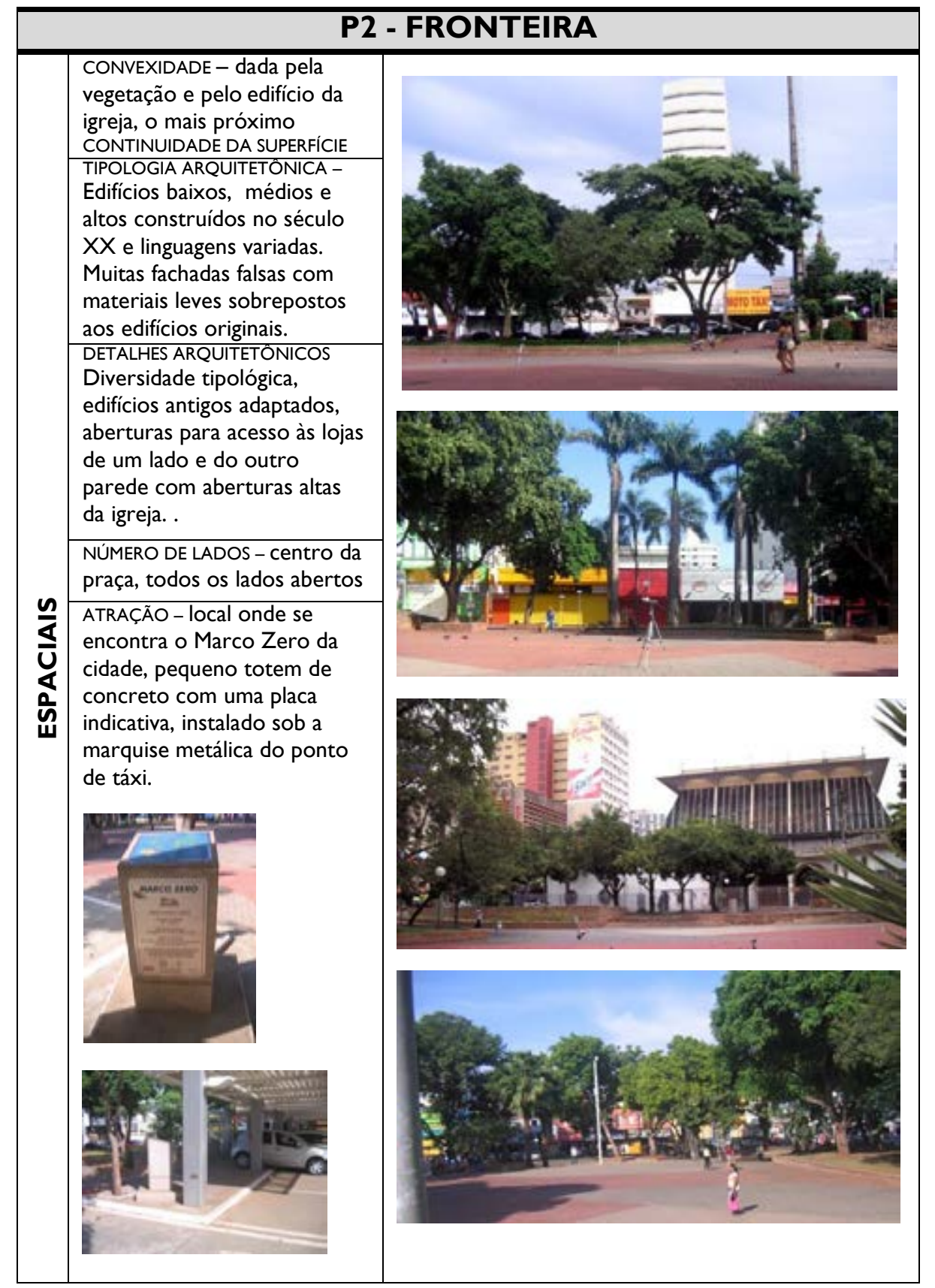




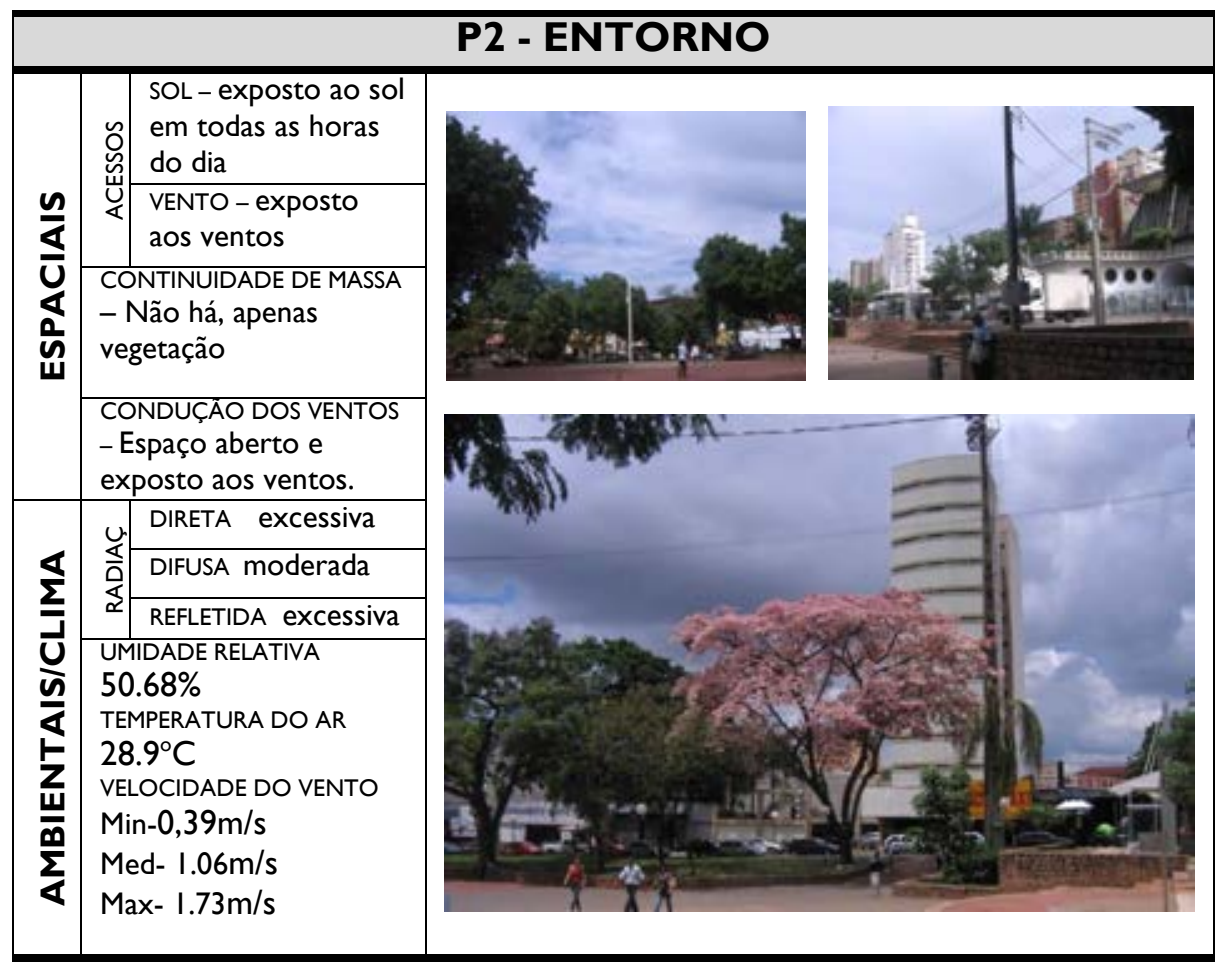




\subsection{I.3 Ficha bioclimática do Ponto 3}

PONTO 3 - CALÇADÃO DA BERNARDINO

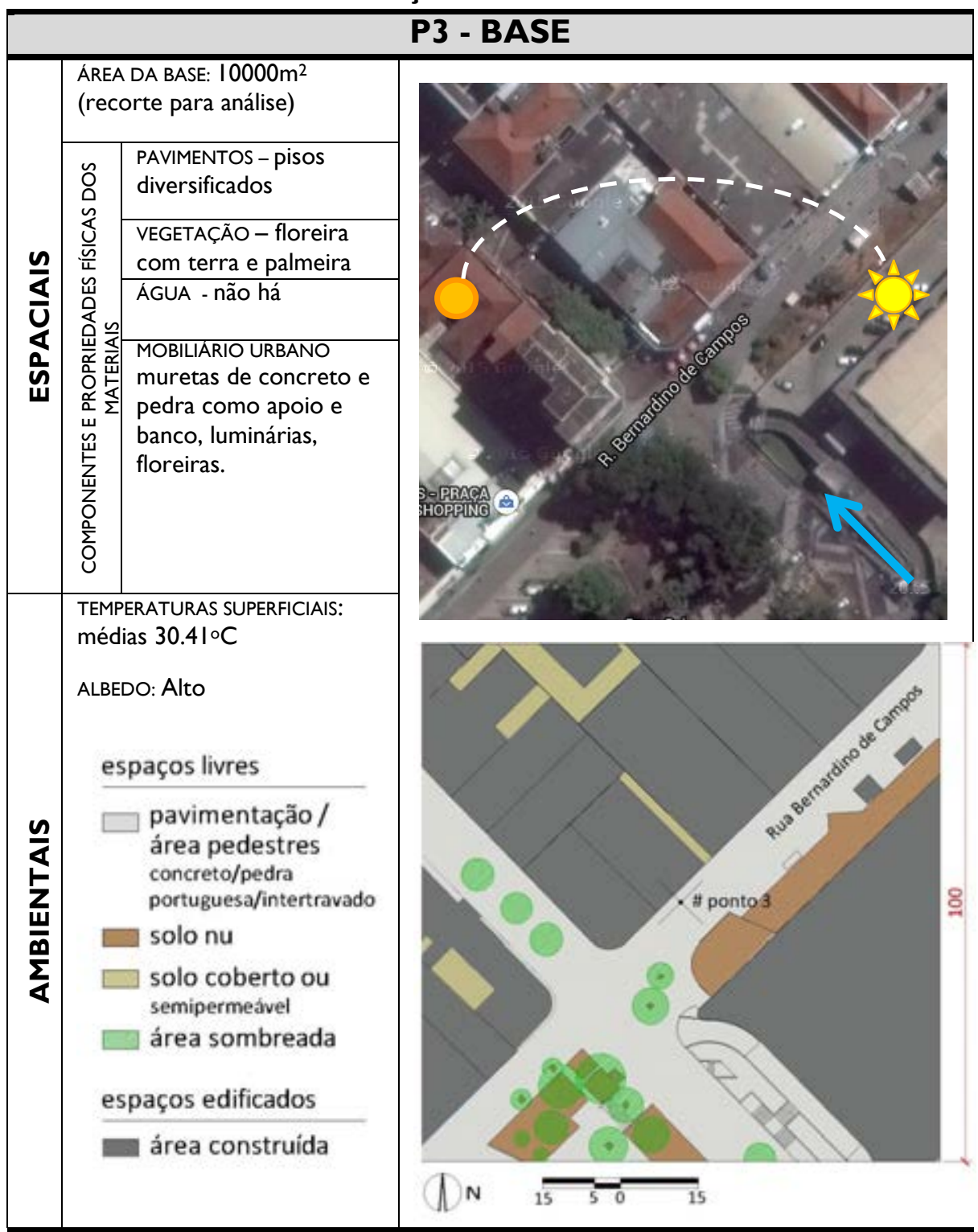




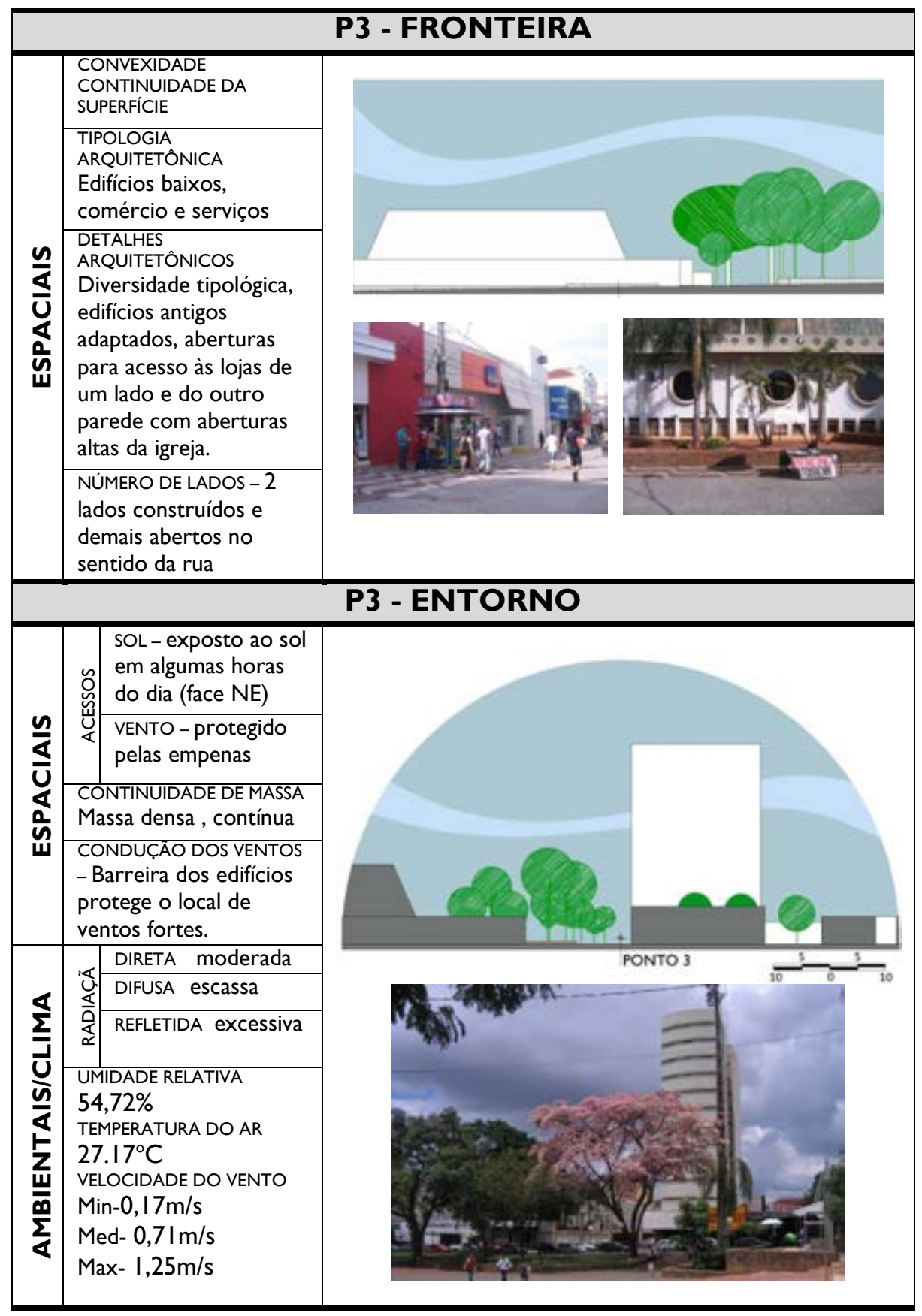




\subsubsection{Caracterização do microclima nos pontos de medição}

\subsubsection{Temperatura e umidade do ar}

Objetivo I: Comparar as variáveis de temperatura e do ar e umidade relativa do ar nos três pontos de medição e estação automática, considerando dias e horários de medições. Com a análise destes dados, foi possível observar que o ponto I apresentou temperatura inferior a da estação automática da Cetesb, mesmo encontrando-se inserido na malha densa do centro urbano. Já no ponto 2 , foi constatada a maior temperatura e menor umidade do ar. Estas observações remetem para as características morfológicas dos pontos, onde o ponto I é o mais sombreado e protegido do sol pela vegetação e sombra dos edifícios à tarde.

Tabela II - Temperatura do ar média e umidade relativa média em todos os períodos, dias e horários, para cada ponto de medição.

\begin{tabular}{|l|c|c|}
\hline PONTOS & TEMP. MÉDIA & UMID. MÉDIA \\
\hline PI & $25,8^{\circ} \mathrm{C}$ & 60.17 \\
\hline P2 & $28,9^{\circ} \mathrm{C}$ & 50.68 \\
\hline P3 & $27,17^{\circ} \mathrm{C}$ & 54.72 \\
\hline CETESB & $25,82^{\circ} \mathrm{C}$ & 67.11 \\
\hline Média Geral & $26,92^{\circ} \mathrm{C}$ & 58,17 \\
\hline
\end{tabular}




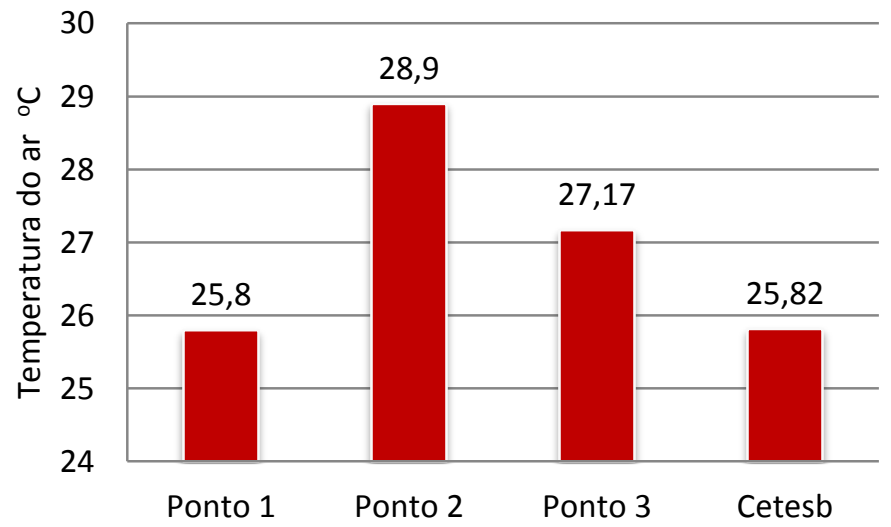

Figura 38 - Gráfico do comportamento da temperatura do ar $\left({ }^{\circ} \mathrm{C}\right)$ média nos pontos de medição e na estação automática Cetesb, em todos os dias e horários de medição.

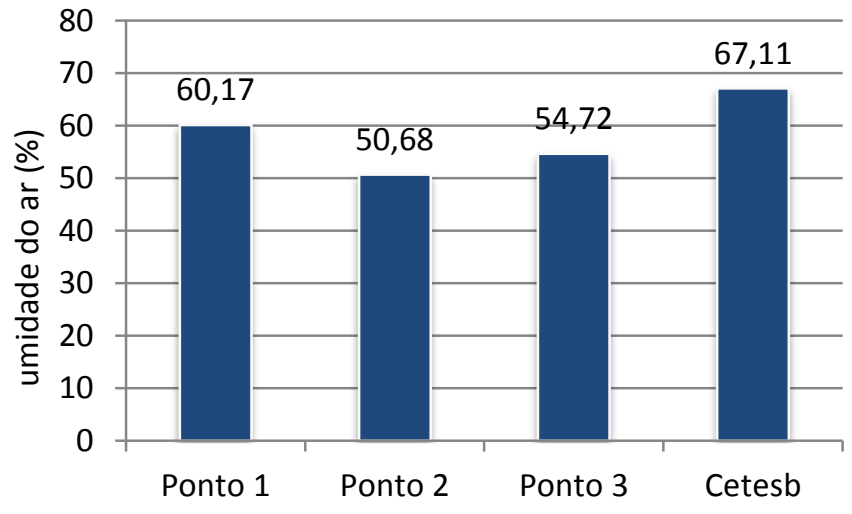

Figura 39 Gráfico do comportamento da umidade do ar (\%) nos pontos de medição e na estação automática Cetesb, em todos os dias e horários de medição. 


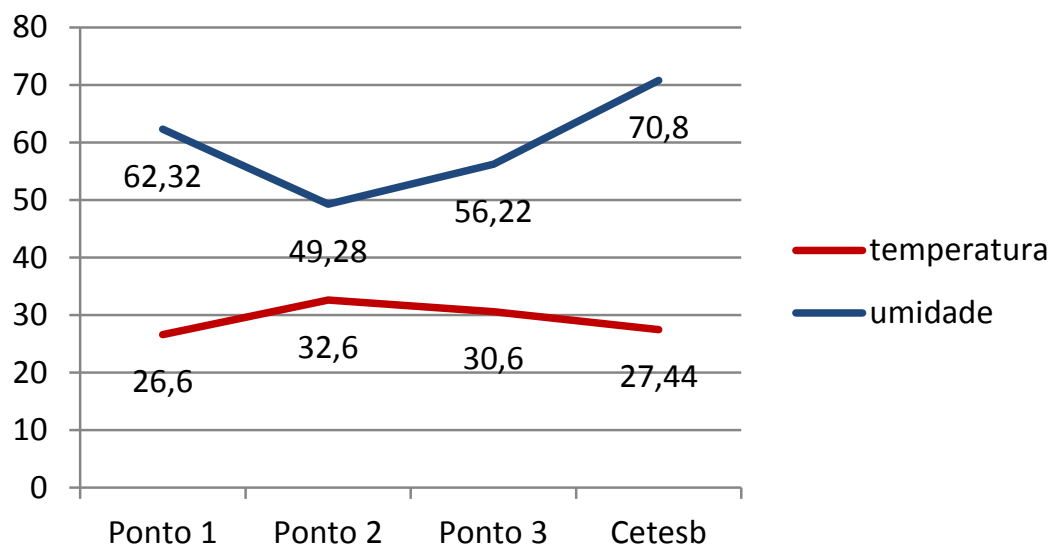

Figura 40 Temperatura e umidade do ar nos pontos amostrais aferidos no dia I (17/03/13)

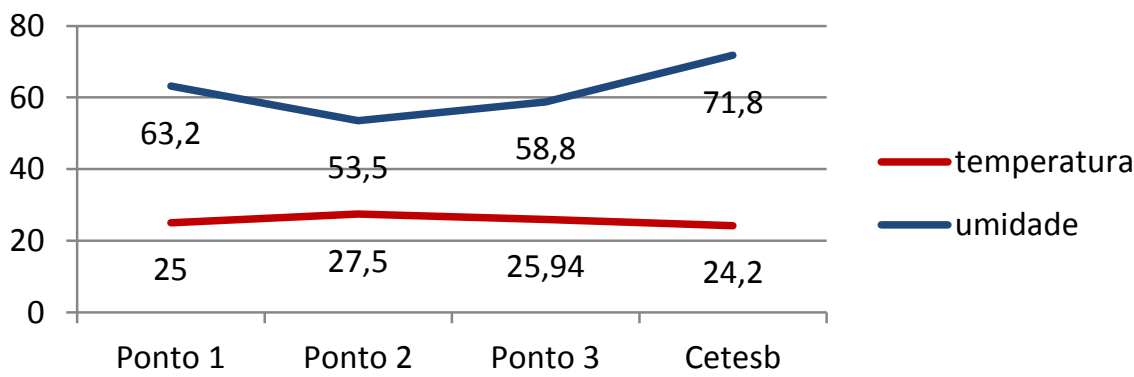

Figura 4I Temperatura e umidade do ar nos pontos amostrais aferidos no dia 2 (I8/03/I3)

3.2.2.2 Medições manuais de temperatura do ar e velocidade do vento Objetivo 2: Comparar as variáveis de velocidade do vento nos três pontos de medição e estação automática, considerando dias e horários de medições, relacionando-as com as aferições de temperatura do ar. Foi possível observar que $\circ$ ponto 3 apresenta menor temperatura, fator atribuído a morfologia do entorno densamente edificado. A velocidade do vento da estação automática da Cetesb registra média bem acima dos 
pontos amostrais, indicando que a configuração mais aberta do bairro pode contribuir para melhor ventilação.

Tabela 12- Velocidade do vento em todos os períodos, dias e horários, para cada ponto de medição.

\begin{tabular}{|l|c|c|c|}
\hline PONTOS & $\begin{array}{c}\text { VELOCIDADE } \\
\text { VENTO MÉDIA } \\
\text { MíNIMA m/s }\end{array}$ & $\begin{array}{c}\text { VELOCIDADE VENTO } \\
\text { MÉDIA MÁXIMA m/s }\end{array}$ & $\begin{array}{c}\text { VELOCIDADE } \\
\text { VENTO MÉDIA } \\
\mathbf{m} / \mathbf{s}\end{array}$ \\
\hline PI & 0,32 & 1,59 & 0,91 \\
\hline P2 & 0,39 & 1,73 & 1,06 \\
\hline P3 & 0,17 & 1,25 & 0,71 \\
\hline CETESB & - & - & 2,95 \\
\hline
\end{tabular}

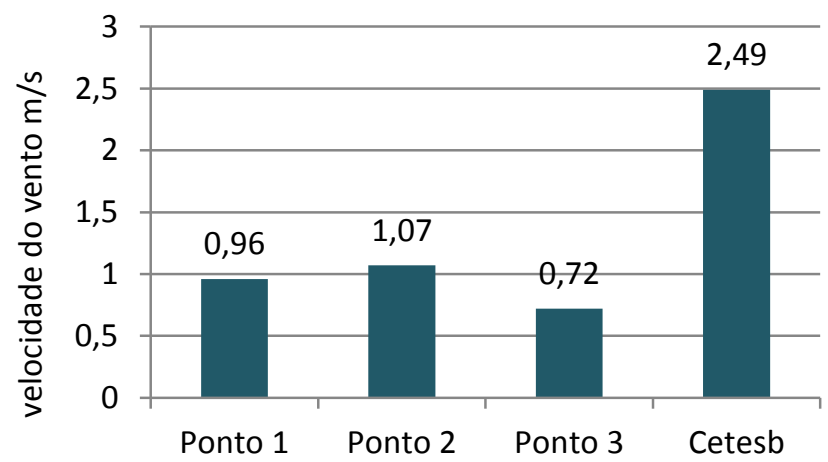

Figura 42 Gráfico do comportamento da velocidade do vento nos pontos de medição e na estação automática da Cetesb, em todos os dias e horários de medição.

Ao relacionar os dados de temperatura e umidade do ar e velocidade do vento, observa-se que no ponto 2 , mesmo com maior velocidade de vento, a umidade do ar é menor e as temperaturas são mais altas, diferente do comportamento observado na estação meteorológica da Cetesb, onde para 
umidade alta e maior velocidade de vento, corresponde uma temperatura menor.

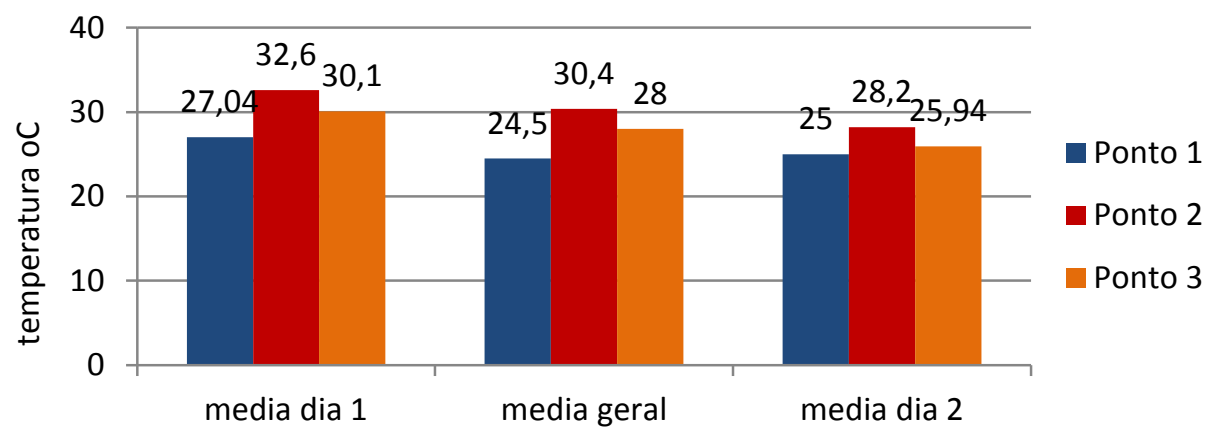

Figura 43 - Gráfico de temperatura do ar (medição manual) nos pontos de medição em todos os dias e horários de medição.

\subsubsection{Temperatura de superfície - recobrimento do solo}

Objetivo 3: Comparar as variáveis de temperatura de materiais de recobrimento do solo relacionando-as com a configuração do ponto amostral. $\mathrm{O}$ concreto foi o único material apresentado nos três pontos, apontando o ponto 2 com maior temperatura, devido à ausência de sombreamento e o ponto I, o mais sombreado, com as temperaturas mais baixas. 


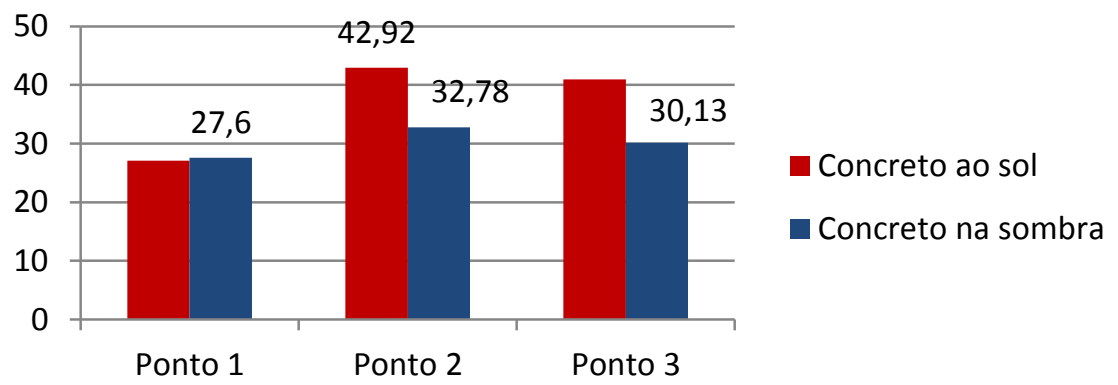

Figura 44 - Temperatura média de recobrimento do solo nos três pontos, concreto ao sol e à sombra

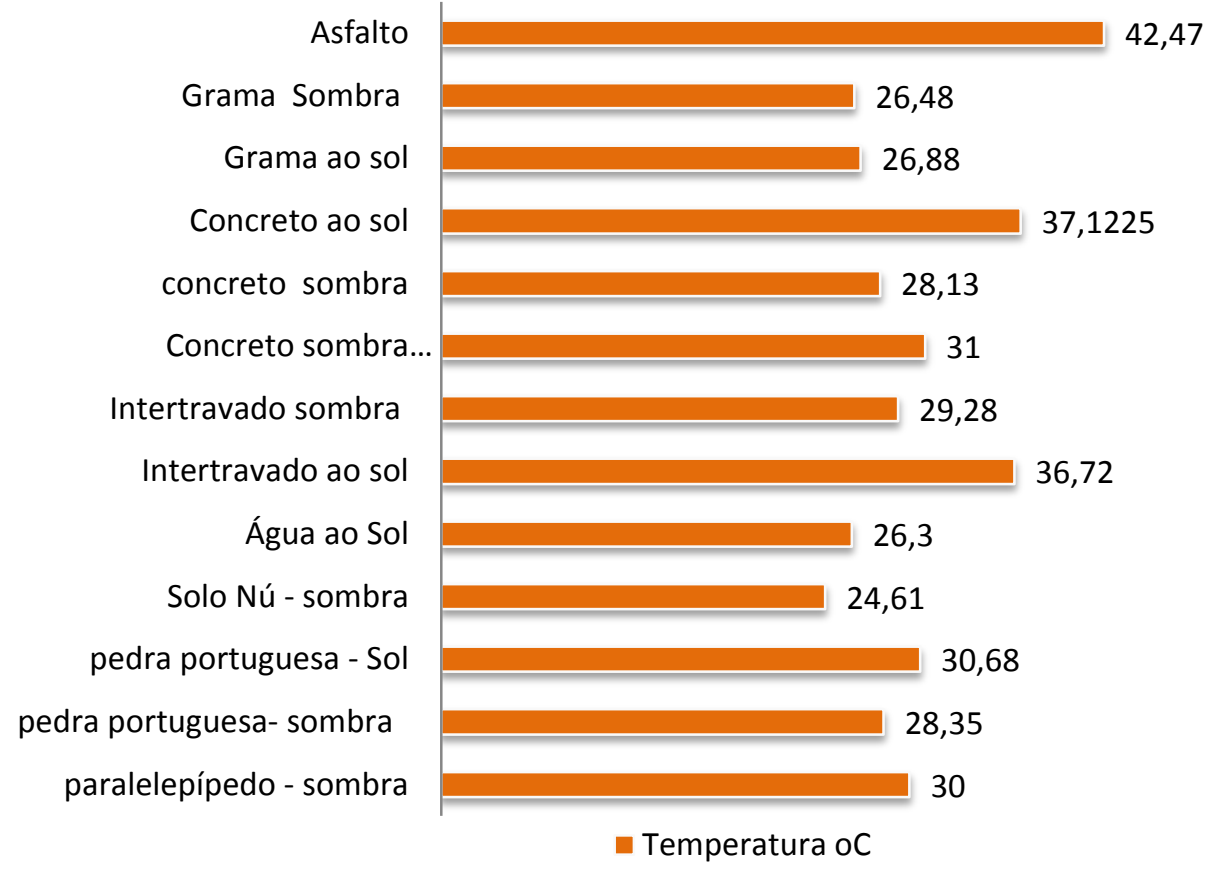

Figura 45 - Temperatura de materiais de superfície de recobrimento do solo nos três pontos, em todos os dias e horários de medições. 


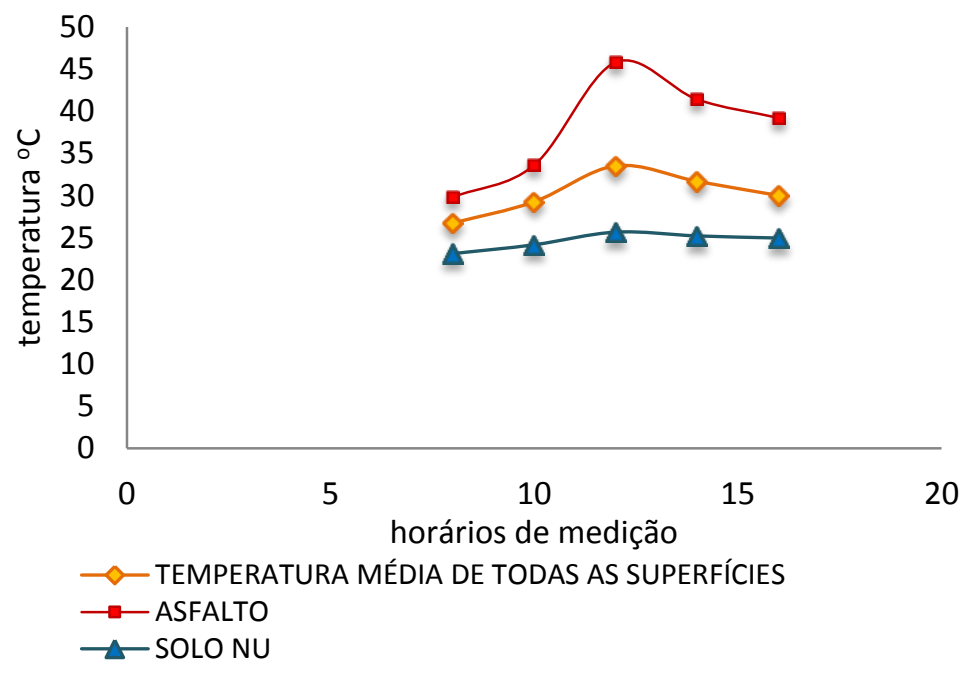

Figura 46 - Gráfico do comportamento da temperatura superficial de materiais com temperaturas extremas (asfalto - máxima / solo nu - mínima), aferido em todos os dias e horários de medição.

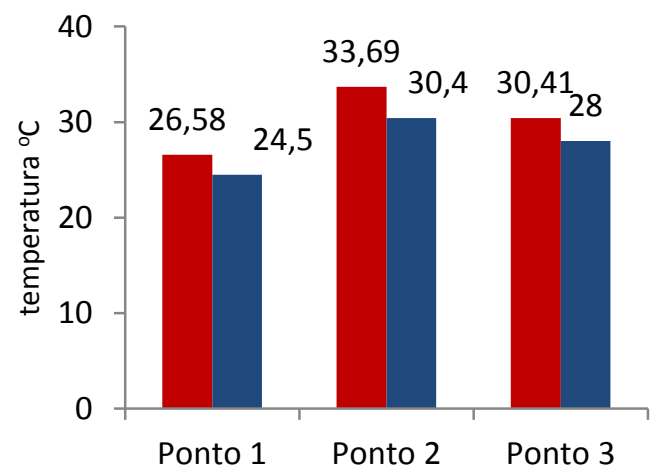

- Temperatura média de materiais de superfície

Figura 47 - Temperatura média de superfície e temperatura do ar por ponto de medição aferidas em todos os dias e horários.

Foi possível observar que o comportamento térmico das superfícies de recobrimento do solo está diretamente relacionado às características dos materiais, mas também à configuração do ambiente físico onde está 
inserida. Os pontos 2 e 3 apresentaram temperaturas médias muito altas, atribuídas à ausência de solo permeável e sombreamento. Ao comparar as temperaturas de superfície e do ar, conclui-se que os materiais estão relacionados proporcionalmente às temperaturas maiores ou menores no ambiente térmico.

\subsubsection{Perfil e comportamento do usuário}

O universo da pesquisa realizada com os usuários dos três pontos corresponde a uma média de uma ou mais entrevistas a cada aferição de temperatura e velocidade do vento em todos os pontos, dias e horários de medição, totalizando 83 entrevistas realizadas..

\subsubsection{Perfil do usuário}

A análise dos números apresenta $43 \%$ dos entrevistados com idade entre 25 e 44 anos e $25 \%$ com mais de 45 anos, correspondendo a um público predominantemente adulto, masculino e da raça branca.

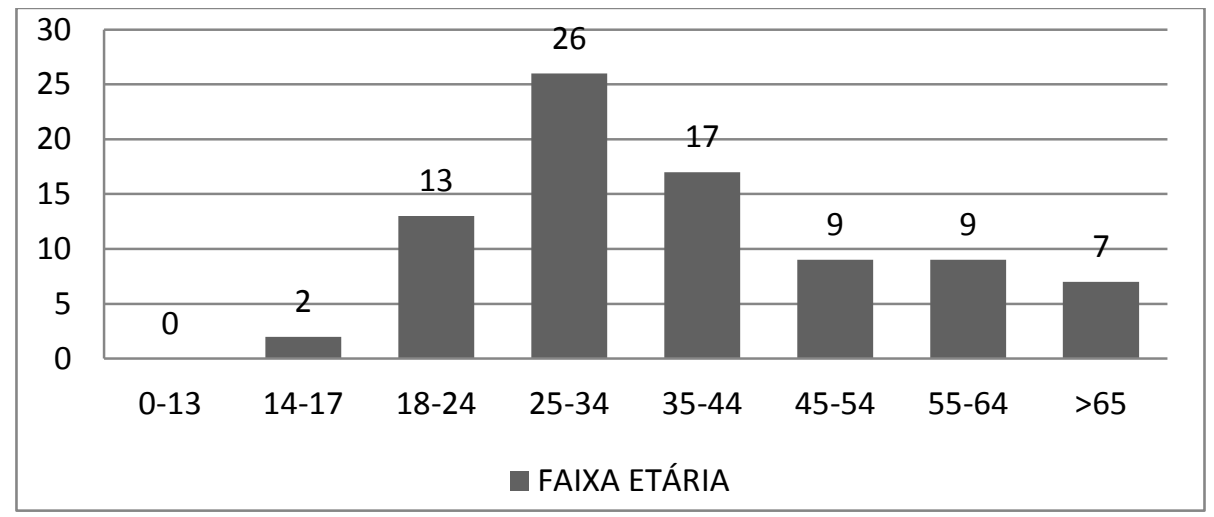

Figura 48: Distribuição de entrevistados por faixa etária em número absoluto 
34

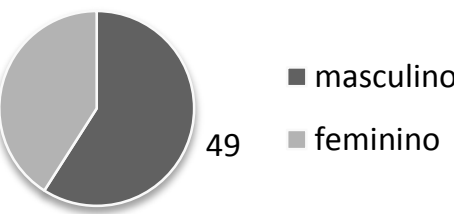

24

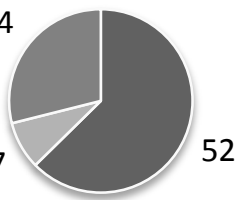

branco

latinoamericano

negro

Figura 49: Número absoluto de Figura 50 - Número de entrevistados por raça entrevistados por gênero

12

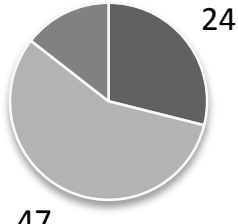

magro

normal

obeso

47

Figura 5 I - Condição física dos entrevistados em número absoluto

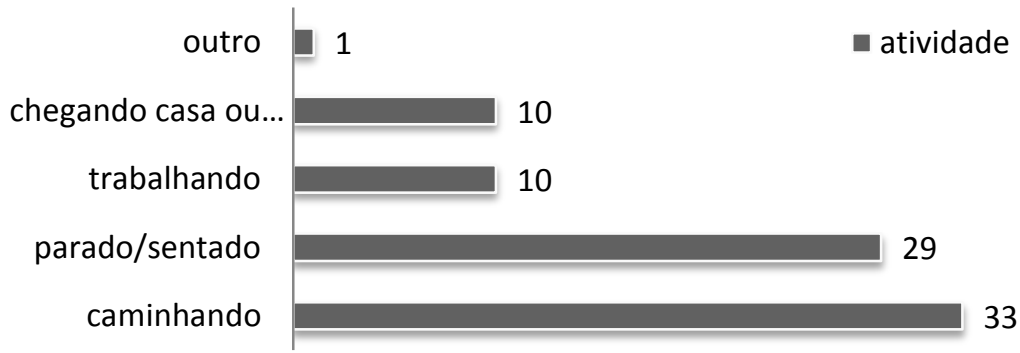

Figura 52 - Gráfico da atividade realizada pelo entrevistado no momento da entrevista 
Ao analisar dados da condição física do usuário e atividade realizada no momento da entrevista, conclui-se que a maioria tem boa condição física, nem magro nem obeso e está em atividade de recreação (caminhando).

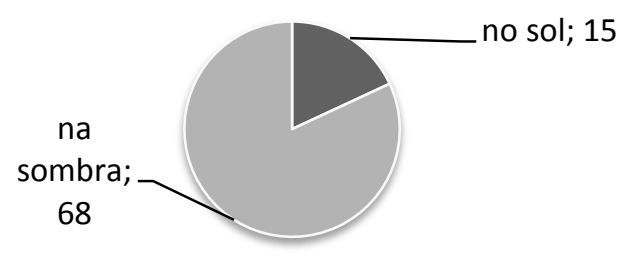

Figura 53 - Distribuição dos entrevistados sob a condição de sombra ou sol no momento da entrevista

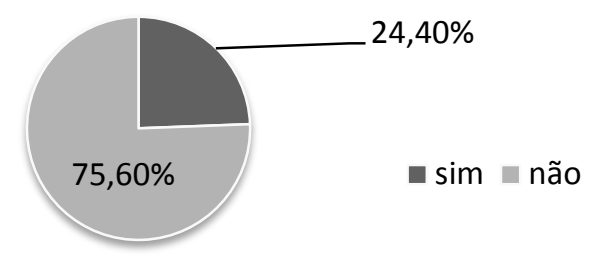

Figura 54 - Análise se entrevistados estavam no sol 5 minutos antes da entrevista

Observa-se que a maioria, cerca de $70 \%$, dos entrevistados estava na sombra, antes da entrevista e pouco antes da entrevista. 
3.2.3.2 Análise da frequência dos entrevistados ao local

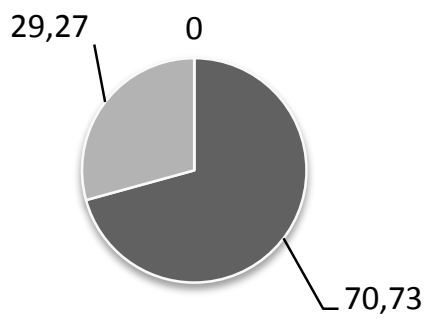

$$
\begin{aligned}
& \text { sempre } \\
& \text { raramente } \\
& \text { nunca }
\end{aligned}
$$

Figura 55 - Análise da frequência ao local em números relativos

Através destes dados é possível constatar que existe um público que frequenta $\circ$ local com regularidade e também observar que nenhum entrevistado desconhece o local por nunca ter estado nele anteriormente.

\subsubsection{Análise do resultado das entrevistas e discussões}

\subsubsection{Sensação Térmica}

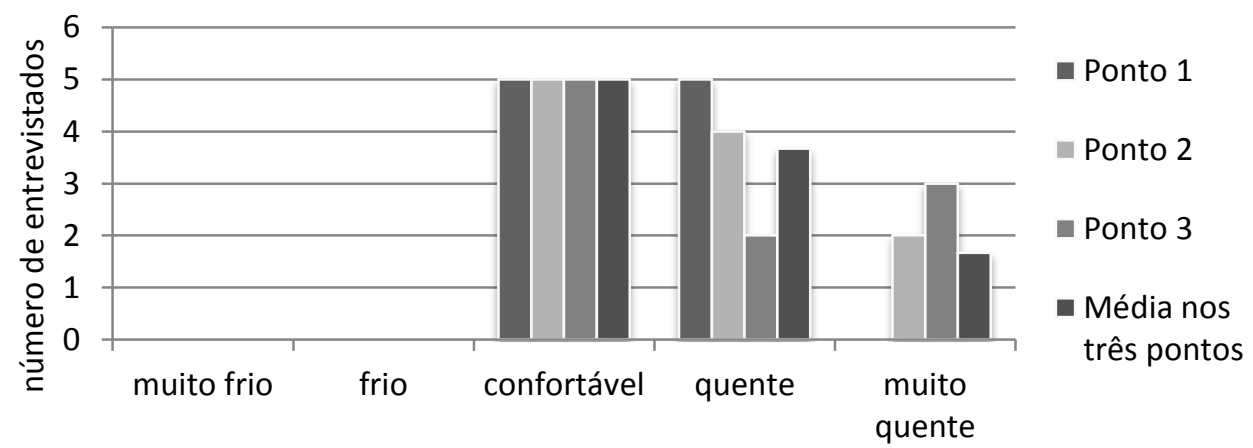

Figura 56 - Sensação térmica média em todos os horários e pontos no dia 17/03/2013 


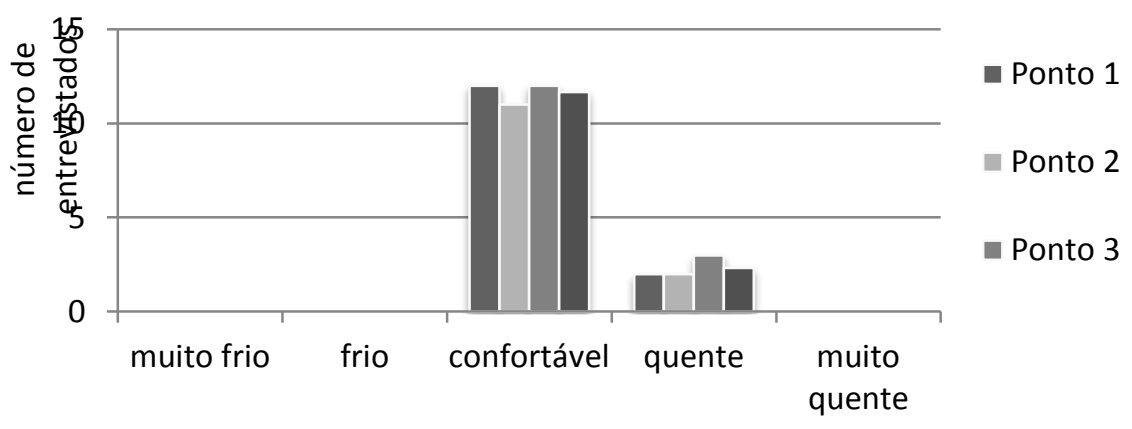

Figura 57 - Sensação térmica média em todos os horários e pontos no dia I8/03/20I3

Cerca de metade das entrevistas com os usuários no dia I registou sensação térmica confortável e a outra metade dividiu-se entre 'quente' e muito quente'. Já no dia 2, quando o céu ficou encoberto por nuvens de chuva, a grande maioria disse estar 'confortável'. 


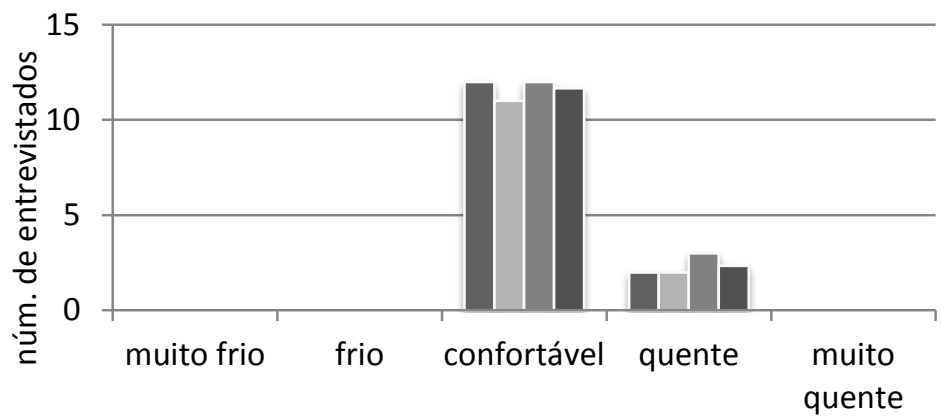

- Ponto 1

Ponto 2

Ponto 3

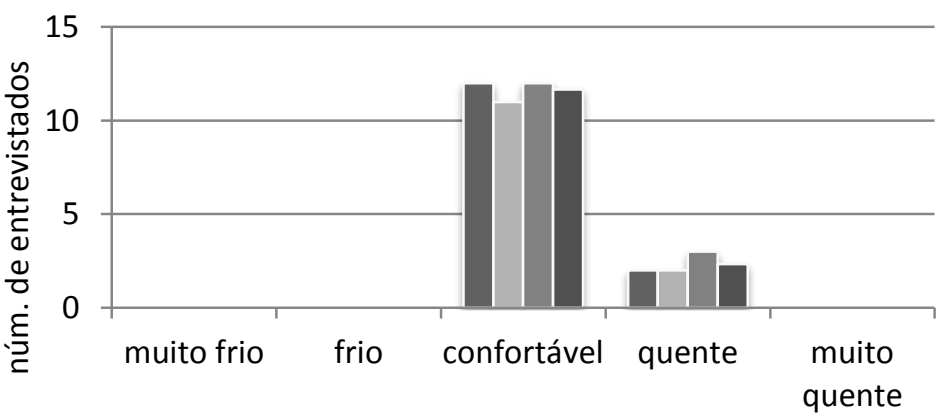

Ponto 1

Ponto 2

Ponto 3

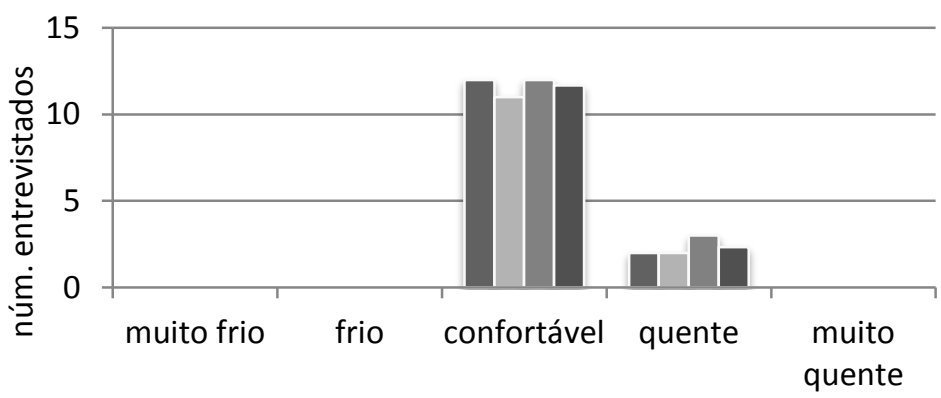

Ponto 1

Ponto 2

Ponto 3 


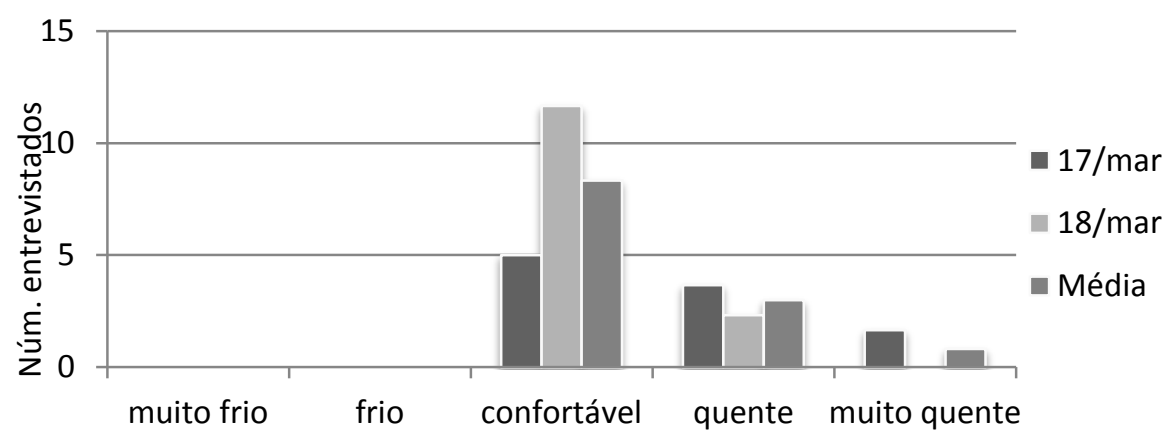

Figura 58 - Sensação térmica média em todos os horários, dias e pontos de medição.

Os dados acima mostram que o número de usuários em sensação térmica confortável no dia I é equivalente àquele que respondeu quente ou muito quente. Já no dia 2 , quando o céu encobriu-se de nuvens de chuva, a maioria sente-se confortável.

\subsubsection{Preferência Térmica}

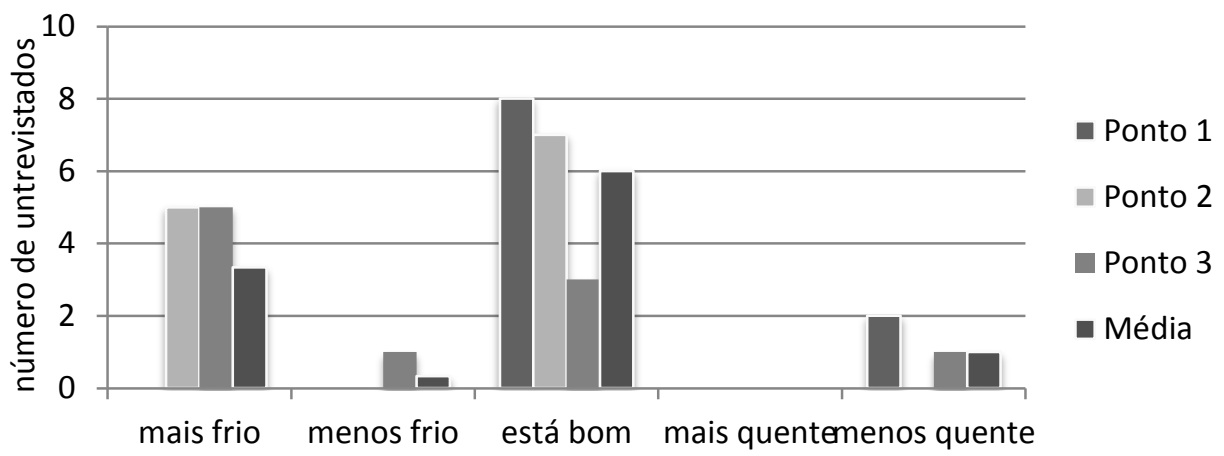

Figura 59 - Preferência térmica em todos os pontos e horários de medição no dia $17 / 03 / 2013$ 
Na preferência térmica do usuário predomina 'está bom', seguido de 'mais frio' e 'menos quente', respostas da maioria masculina em desconforto.

\subsubsection{Análise da preferência térmica $X$ sensação térmica}

\begin{tabular}{|l|c|c|c|c|c|c|}
\hline PREFERËNCIA & \multicolumn{2}{|c}{ MASC. } & \multicolumn{3}{c|}{ FEMIN. } & \multicolumn{2}{c|}{ TOTAL } \\
\hline TÉRMICA & $\mathrm{N}^{\circ}$ & $\%$ & $\mathrm{~N}^{\circ}$ & $\%$ & $\mathrm{~N}^{\circ}$ & $\%$ \\
\hline mais frio & $\mathrm{II}$ & 22 & 7 & 21,9 & 18 & 21,9 \\
\hline menos frio & $\mathrm{I}$ & 2 & 4 & 12,5 & 5 & 6,10 \\
\hline está bom & 33 & 66 & 15 & 46,9 & 48 & 58,5 \\
\hline mais quente & 2 & 4 & 5 & 15,6 & 7 & 8,6 \\
\hline menos quente & 3 & 6 & $\mathrm{I}$ & $3, \mathrm{I}$ & 4 & 8,9 \\
\hline TOTAL & 50 & $6 \mathrm{I}$ & 32 & 39 & 82 & 100 \\
\hline
\end{tabular}

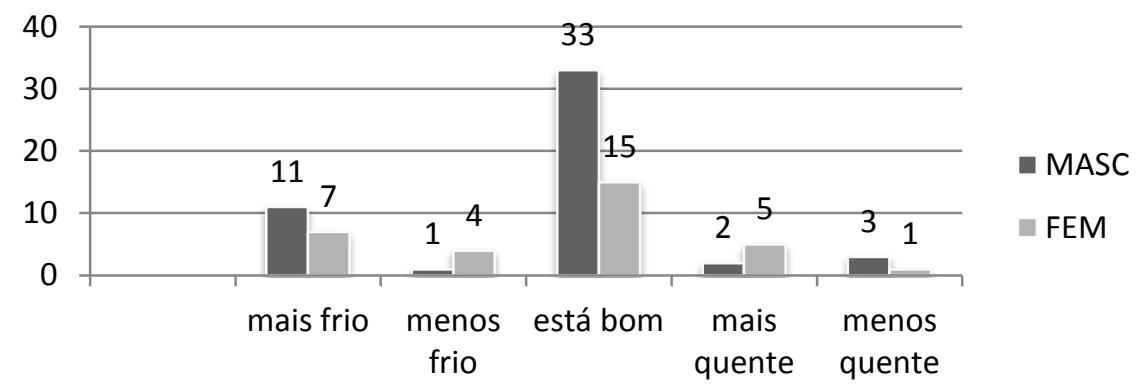

3.2.4.4 Análise da percepção da ventilação $X$ velocidade do vento

Tabela I 3 - Relação entre a velocidade média do vento e a percepção do usuário

\begin{tabular}{l|c|c|c|c|c|c|c|c|}
\hline PERCEPÇÃO DA & \multicolumn{3}{|c|}{ DIA I } & \multicolumn{3}{c}{ DIA 2 } & \multicolumn{3}{c|}{ TOTAL } \\
\hline VENTILAÇÃO & $\mathrm{PI}$ & $\mathrm{P} 2$ & $\mathrm{P} 3$ & $\mathrm{PI}$ & $\mathrm{P} 2$ & $\mathrm{P3}$ & $\mathrm{N}^{\circ}$ & $\%$ \\
\hline Média velocidade vento & 0,66 & $\mathrm{I}, 05$ & 0,59 & 1,26 & $\mathrm{I}, 15$ & 0,85 & & \\
\hline há pouco vento & 2 & 5 & 8 & 4 & $\mathrm{I}$ & 5 & 25 & 30,5 \\
\hline está ventando & 8 & 7 & 2 & 13 & 13 & 10 & 53 & 64,6 \\
\hline há muito vento & 0 & 0 & 0 & 2 & 2 & 0 & 4 & 4,9 \\
\hline Total & 10 & 12 & 10 & 19 & 16 & 15 & 82 & 100
\end{tabular}


Os dados acima confirmam que a média da velocidade do vento aferida corresponde à percepção do pedestre. Ou seja, nos pontos com menor velocidade de vento, uma maior porcentagem de entrevistados identifica que há pouco vento.
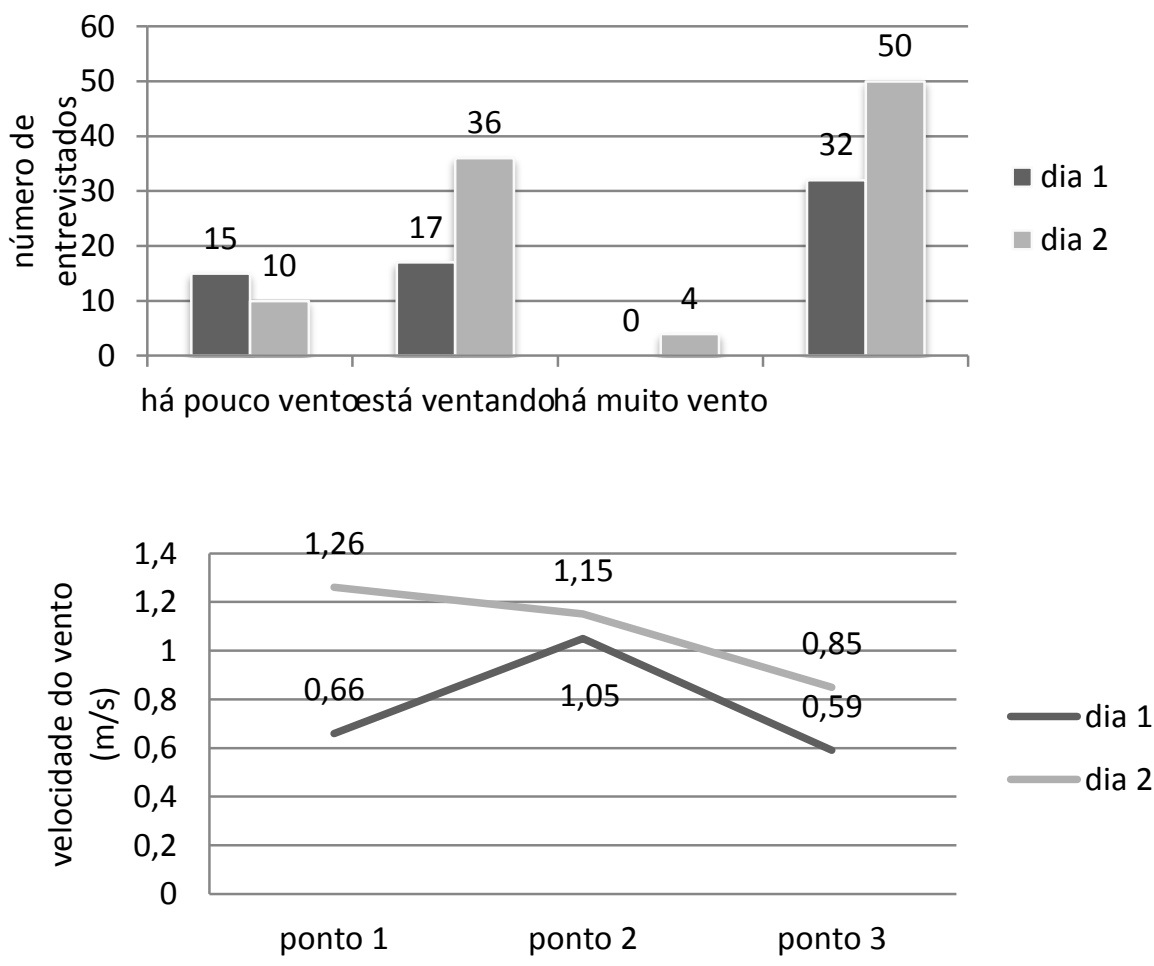
3.2.4.5 Análise da percepção da umidade $X$ média umidade relativa do ar

Tabela 14 - Percepção da umidade e umidade relativa do ar nos três pontos de medição.

\begin{tabular}{|l|l|l|l|l|} 
& total & PI & P2 & P3 \\
\hline UMID. MÉDIA & & 60.17 & 50.68 & 54.72 \\
\hline úmido & 36 & 14 & 14 & 8 \\
\hline seco & 35 & 8 & 11 & 16 \\
\hline não sei & 11 & 7 & 3 & 1
\end{tabular}

\subsubsection{Análise da percepção da luminosidade}

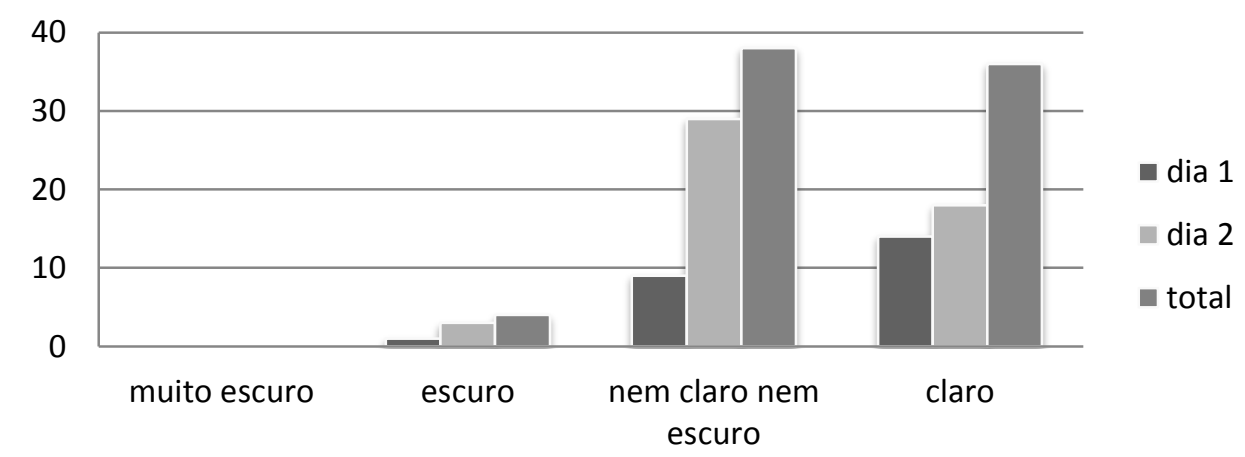

Figura 60 - Análise da percepção da luminosidade em todos os dias e horários de medição

Observa-se que a percepção dos usuários é de conforto em relação à luminosidade e umidade relativa do ar. 


\subsubsection{Principal elemento percebido}

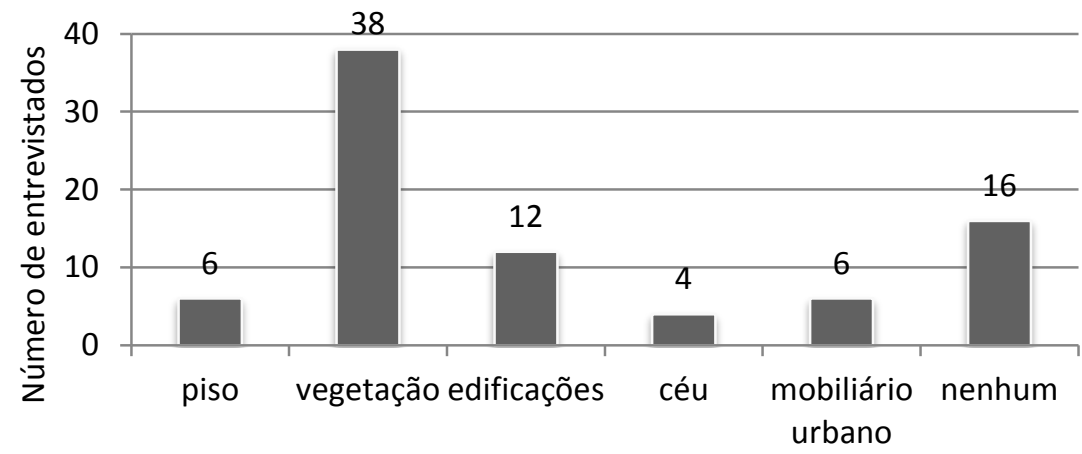

Figura 6I - Análise do principal elemento percebido pelo entrevistado

3.2.4.8 Expectativa dos entrevistados sobre o que mais deveria haver no local

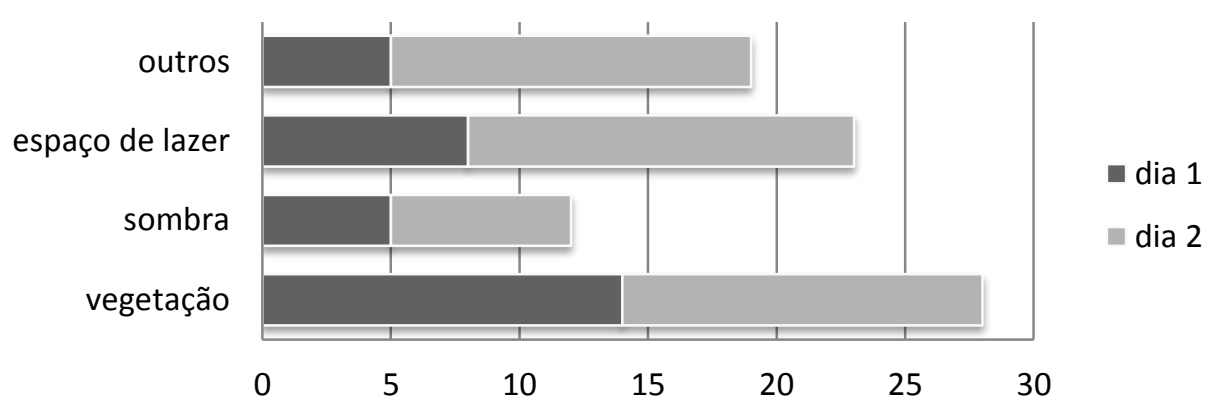




\subsubsection{Conclusão das análises}

As análises demonstraram a influência que as diferentes morfologias de espaços livres provocam no microclima, permitindo identificar quais os atributos e em quais diferentes configurações pode-se chegar a um bom resultado. Sendo assim, o trabalho da pesquisa foi fundamental para atingir os objetivos iniciais colocados e possibilitou a geração de diretrizes para o projeto.

O conjunto de procedimentos metodológicos desenvolvidos por meio do 1) entendimento da morfologia urbana, 2) das observações registradas sistematicamente nas fichas bioclimáticas, 3) da aferição de dados de elementos microclimáticos e 4) da observação do comportamento do usuário permitiu identificar quais os atributos da morfologia dos espaços livres que contribuem com melhores condições do microclima, e estão a seguir descritos e correspondem aos subsídios fundamentais para elaboração das diretrizes de projeto.

- Espaços caracterizados por vegetação arbórea diversificada, de grande e médio porte e copa de menor densidade, geram amplo espaço sombreado e apresentaram menor temperatura do ar e maior umidade relativa do ar. Em comparação desta configuração, inserida na malha do centro urbano com a da estação automática, ela ainda apresenta melhores condições microclimáticas, ou seja, é possível criar condições de conforto com o uso adequado da 
vegetação mesmo que o entorno imediato seja densamente edificado.

- Os espaços em que há ausência da vegetação, mesmo que abertos, com elementos de fronteira a mais de 50 metros, ventilados e com material de superfície de menor albedo, apresentam maior média de temperatura do ar e superficial. Quando a base apresenta extensa área pavimentada e não sombreada o resultado é desfavorável ao conforto e uso do espaço.

- A fronteira delimitada por duas fachadas paralelas em distância menor que 15 metros e altura de até dois pavimentos colaboram com o microclima por meio de sombreamento gerado pela fachada sudeste após as $12 \mathrm{hs} 00$.

- A morfologia espacial é fator determinante no resultado de conforto dos elementos microclimáticos. A ventilação isolada não é suficiente para a melhoria de espaços muito abertos e sem sombreamento. O comportamento térmico de materiais de superfície também varia em função do conjunto da configuração do entorno imediato e não apenas se há ou não sombreamento.

- Os materiais de superfície tem importante papel na definição das condições de conforto, ou seja, aos ambientes cuja média das temperaturas superficiais é maior, correspondem direta e proporcionalmente temperatura do ar também maior. Os materiais de comportamentos extremos são o asfalto com a maior e o solo nu com a menor temperatura de superfície. 
- A escolha do material de superfície deve ser orientada pela sua integração ao contexto do espaço a ser projetado. É o conjunto dos atributos do entorno imediato que contribuem para o comportamento maior ou menor da temperatura superficial.

- O público entrevistado durante a pesquisa de campo apresenta perfil adulto e o local quase não é frequentado por crianças e adolescentes até 17 anos. Cerca de $70 \%$ possui boas condições físicas (magro ou normal) e estava caminhando no momento da entrevista. A maioria frequenta o local regularmente.

- A percepção térmica do usuário mostra correspondência entre os dados de temperatura e umidade relativa do ar. A sensação térmica dividiu-se entre 'confortável' de um lado e 'quente' ou 'muito quente' especialmente no dia I. A preferência térmica também apontou algum desconforto no mesmo período. Quanto a umidade relativa do ar e a luminosidade, os usuários se mostraram em conforto.

- O principal elemento percebido é a vegetação e a expectativa do entrevistado para o local é de que deveria haver mais vegetação e espaços de lazer. 


\section{DIRETRIZES, PROPOSTA DE INTERVENÇÃO E CONCLUSÕES}

A conclusão das análises permite a geração de diretrizes para o projeto da área localizada no centro da cidade de São Jose do Rio Preto, considerando a influência que as diferentes morfologias de espaços livres provocam no microclima.

Observou-se que a temperatura do ar é de fato maior na área central da cidade do que em regiões menos urbanizadas, como a Estação meteorológica automática da Cetesb, em função do adensamento e da alta taxa de permeabilidade do solo. Este resultado aponta para a importância de estudos desta natureza fornecerem subsídios ao plano diretor no que diz respeito a esta área de intervenção.

\section{I DIRETRIZES BIOCLIMÁTICAS}

As recomendações a seguir apresentadas podem ser aplicadas a projetos urbanos da área em estudo e adaptadas para projeto de espaços livres em cidades de clima tropical Aw, considerando os atributos específicos de cada configuração da forma urbana.

I. Em projeto bioclimático de espaços livres em cidades de clima tropical Aw, é indispensável o controle do calor excessivo e radiação solar diurna.

2. É imprescindível o uso de elementos de sombreamento em locais onde há a circulação de pedestres. 
3. A árvore pode ser considerada o principal elemento de sombreamento e deve ser distribuída de forma regular e equilibrada em toda a área, evitando o adensamento ou áreas sem árvores.

4. As coberturas para proteção de chuva não substituem a sombra das árvores e podem ser usadas quando complementados pela vegetação (trepadeiras, pérgulas, palmeiras e outros.). Os elementos construídos, como coberturas para proteção solar podem ser utilizados desde que integrados e complementares à vegetação.

5. É necessário reservar áreas com insolação nos períodos de sol ameno (início da manhã e final de tarde) e para tal, deve-se observar a trajetória solar no inverno e verão antes de escolher o local de plantio. Devem ser utilizadas espécies de pouca densidade da copa ou sazonais (caducifólias: árvores que perdem as folhas no inverno).

6. Recomenda-se assegurar e ampliar áreas de superfície natural (terra, gramados ou forrações) em substituição à áreas pavimentadas para reduzir a absorção da radiação solar e a reflexão sobre as superfícies construídas.

7. Deve-se evitar a utilização de materiais de revestimento do solo que reflitam a radiação solar ou armazenem calor e utilizar materiais superficiais de baixo albedo. $O$ uso de grandes superfícies secas de alto albedo tem grande refletividade e não é recomendado em nenhuma hipótese.

8. Proteger os ambientes de estar e permanência do vento carregado de pó em suspensão com anteparos e vegetação. 


\subsection{ANÁLISE DAS SOMBRAS}

A análise a seguir apresenta a influência da morfologia do entorno construído e da vegetação por meio de um modelo 3D da área de projeto. A insolação e o sombreamento do espaço formado pelos edifícios são examinados em situações de aquecimento no período do verão e resfriamento no inverno, uma vez que as necessidades são diferentes para cada estação.

Os diagramas de insolação para cada período e para todas as horas do dia (manhã, meio-dia, à tarde) foram sobrepostos, mostrando os espaços que estão permanentemente expostas ao sol ou à sombra. 
Tabela I5 Mapas de sombras do entorno construído nos dias 21/06 e 2I//2 às 9,12 e 15 hs

hs $21 / 06$ inverno $21 / / 2$ verão

9

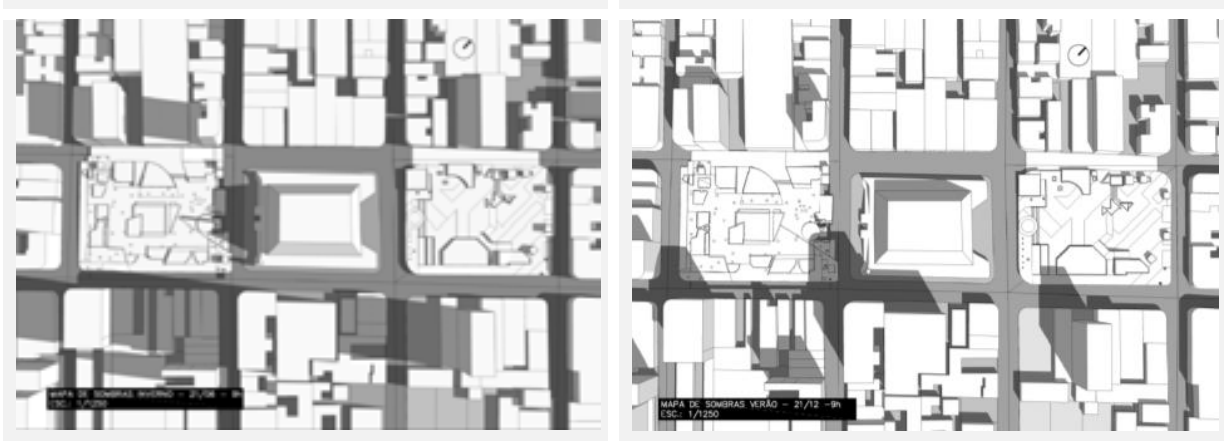

12
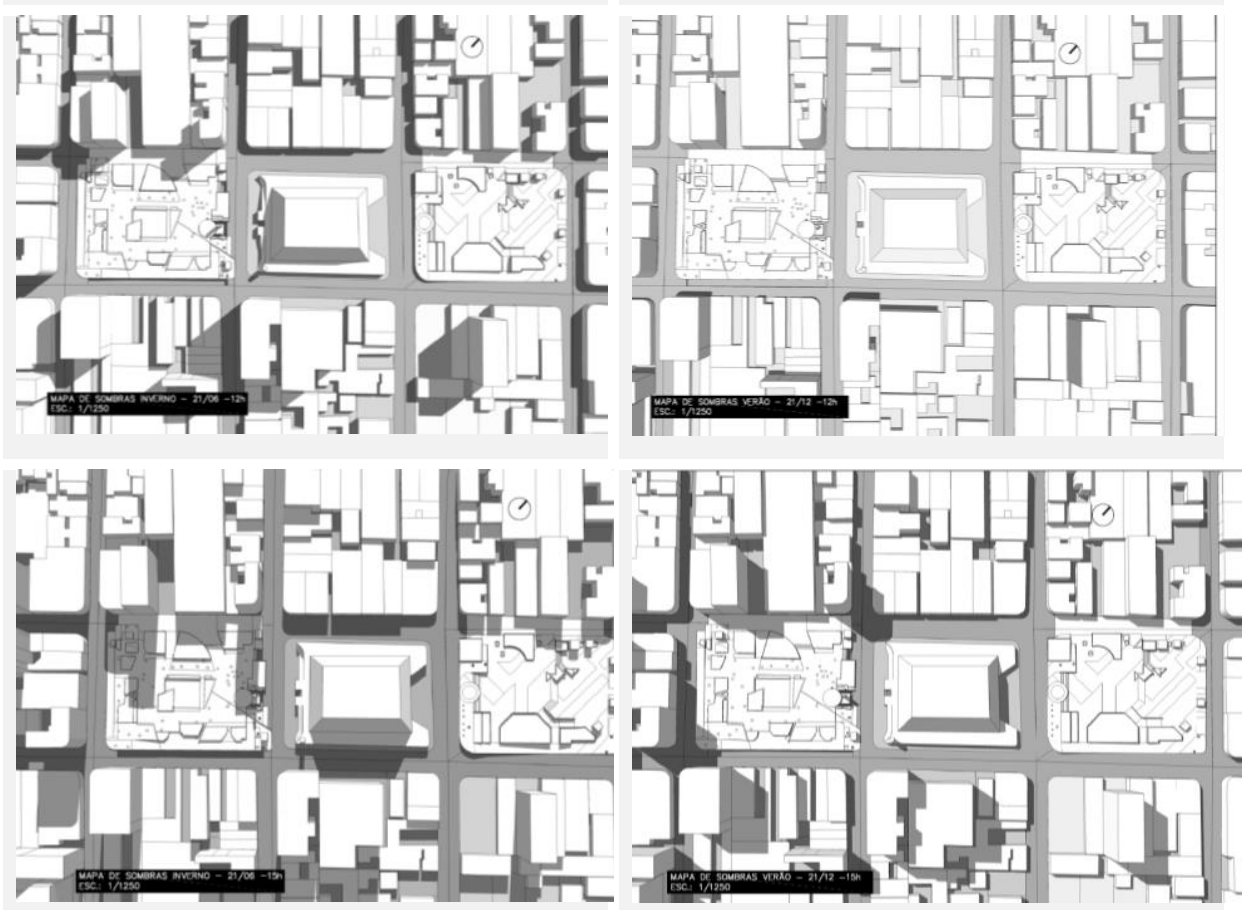
O modelo abaixo mostra a influência da vegetação, a fim de definir as áreas de exposição ao sol e à sombra, diferenciando espécies classificadas como perenifólias ou decíduas, que perdem as folhas no inverno.

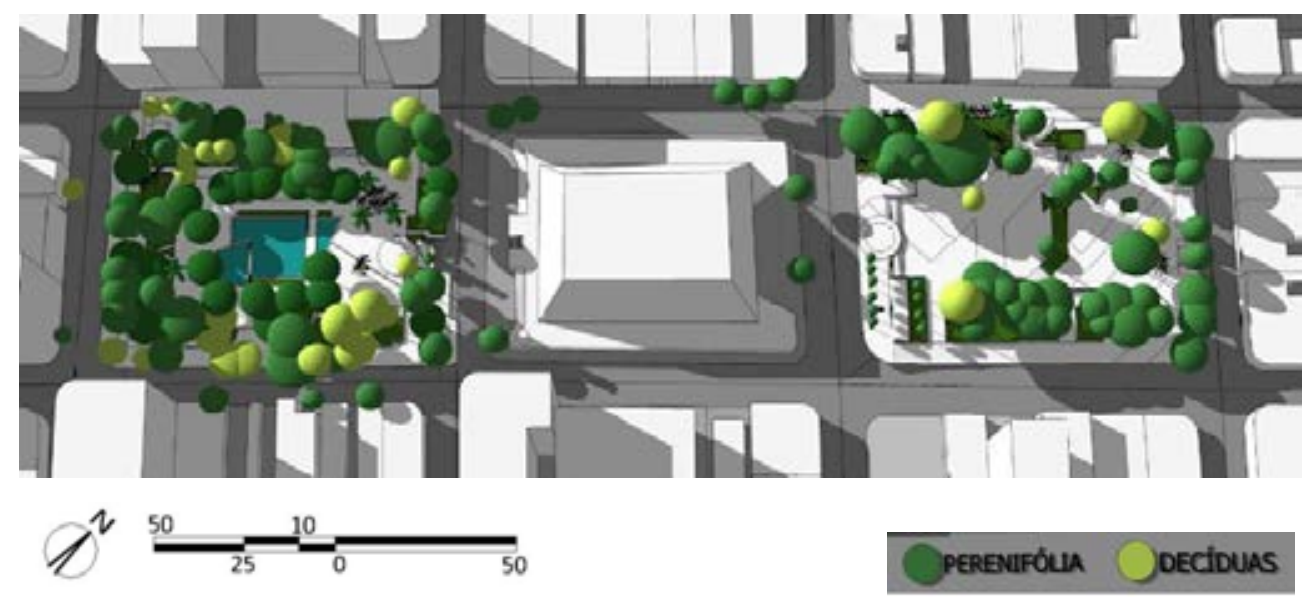

Figura 62 Mapa indicando áreas de sombra e sol em $21 / 12$, às 17 hs00

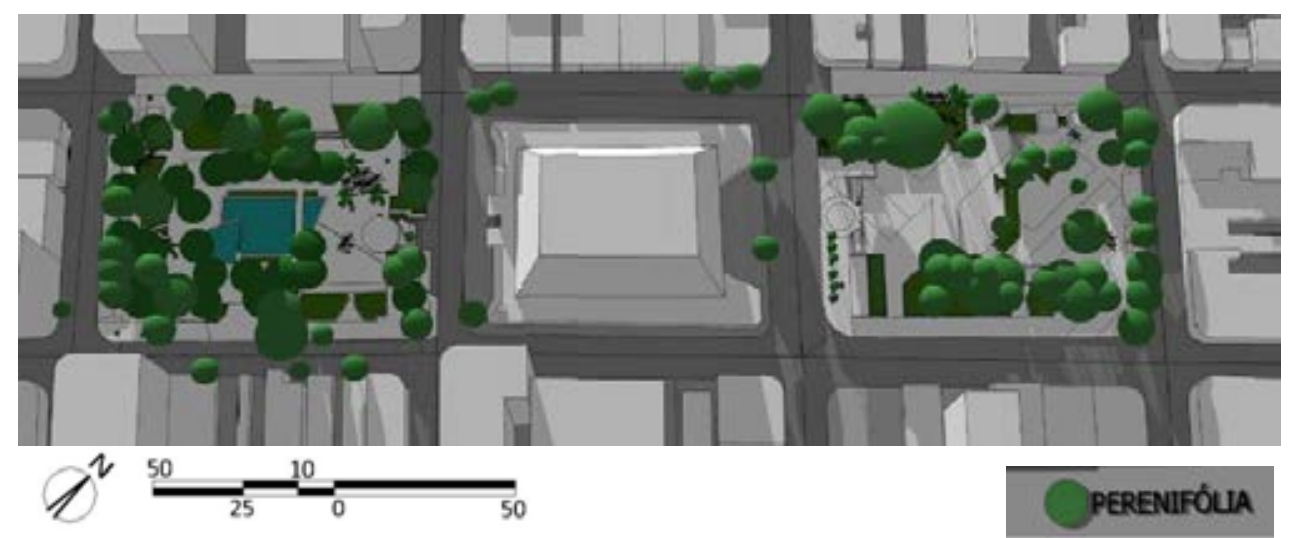

Figura 63 - Mapa indicando áreas de sombra e sol em 21/06 às I7hs00 


\subsection{ETAPAS DE PROJETO}

Para elaboração do projeto, foi necessário buscar outras informações além daquelas já estudadas neste trabalho. $O$ gráfico a seguir apresenta um mapeamento dos principais aspectos observados no local de estudo, considerados aqui como condicionantes de projeto.. Desta forma, esta etapa prévia de projeto foi elaborada a partir das seguintes etapas de trabalho:

a. Identificação das áreas a serem preservadas do ponto de vista microclimático conforme estudo realizado na pesquisa;

b. Identificação do impacto das sombras do entorno construído e da vegetação existente;

c. Identificação de usos, quais os públicos, principais atividades ali desenvolvidas e em que horários. Identificação de apropriações privadas do espaço público, tais como quiosques de operadora de celular, bancas de revistas, mesas de bar na calçada, bancas de revistas e outros;

d. Identificação de acessos, fluxos e deslocamentos,

e. Identificação de equipamentos fixos e serviços (sanitários públicos, pontos de táxi, ônibus e outros);

f. Identificação de vistas importantes e pontos focais e de interesse. 


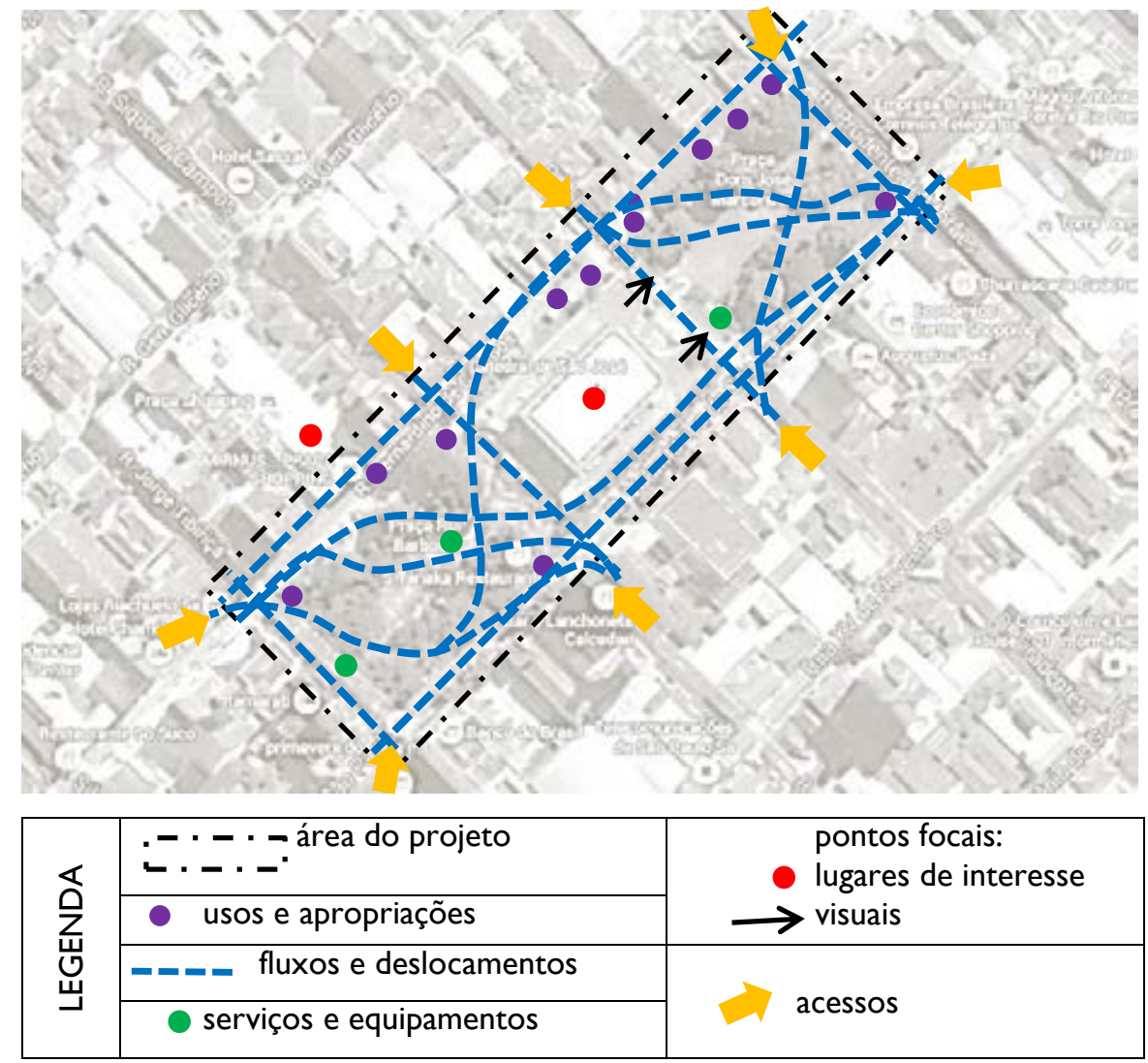

\subsection{DIRETRIZES DE PROJETO}

\subsection{Estratégias para melhoria do microclima}

a) Aumentar o sombreamento no verão das áreas centrais das praças por meio de elementos que atuem como filtros da insolação excessiva tais como espécies de árvores decíduas com copa de baixa densidade, pérgulas e coberturas leves.

b) Criar espaços de estar e permanência com insolação adequada para uso nos períodos mais frios do inverno. 
c) Ampliar a área de superfície natural (terra, gramados ou forrações) para garantir a drenagem e minimizar os efeitos negativos da radiação solar direta.

d) Utilizar materiais superficiais de baixo albedo associados a outros elementos como vegetação, boa orientação solar e outros.

e) A análise da umidade relativa do ar realizada com base nos dados climáticos locais mostrou não haver a necessidade de umidificação do ambiente por meio de elementos como lâminas d'água ou chafariz.

f) Considerar toda espécie arbórea como elemento existente e evitar sua remoção em qualquer circunstância, exceto quando tratar-se de questão de segurança ao usuário.

g) Utilizar anteparos com a presença da vegetação para proteger os ambientes de estar e permanência de ventos mais fortes (sudeste) carregados de pó em suspensão e frios (nordeste a sudeste).

\subsubsection{Estratégias para adequação dos espaços livres ao uso e escala humana}

a) Criar ambientes adequados ao pedestre nos aspectos de acessibilidade e escala e conforto térmico.

b) Estabelecer tipologias de espaços livres: boulevard comercial, terraço jardim, nichos de permanência, pérgulas, praças (de acesso, de estar, do sol), pequenas construções modulares para serviços e comércio de micro porte, entre outros. 
c) Criar conexão entre os espaços livres definindo uma hierarquia de passeios a eles relacionados e aos objetivos de fluxos.

d) Melhorar as condições de passeio na área comercial, estabelecendo a continuidade do percurso livre de obstáculos, por meio de piso homogêneo, mobiliário adequado e arborização. Definir uma identidade ao local com a criação de um boulevard.

e) Minimizar o problema da drenagem no passeio comercial através da implantação de canteiro pluvial ${ }^{16}$ ou outra solução similar.

\subsubsection{Aplicação de princípios bioclimáticos ao desenho urbano de área no Centro de São José do Rio Preto}

Conforme exposto no capítulo I, a caracterização climática do lugar, o entendimento do microclima e a aplicação das metodologias de pesquisa de campo são ferramentas úteis na elaboração do projeto de ambientes urbanos e espaços livres. Cabe ao projetista interpretá-las e gerar alternativas espaciais como resposta, atividade desenvolvida como simulação ou ensaio projetual por meio da proposta de intervenção e readequação bioclimática da área central de São José do Rio Preto.

${ }^{16}$ Canteiros pluviais são pequenos espaços urbanos destinados à drenagem que pode ocorrer por infiltração, evaporação, evapotranspiração ou transbordamento. (PELLEGRINO, CORMEIR, 2008) 


\begin{tabular}{l|l|l}
$\begin{array}{l}\text { Tabela } 16 \\
\text { projeto } \\
\text { Elemento a } \\
\text { controlar }\end{array}$ & Clima quente-úmido & premissa \\
$\begin{array}{l}\text { temperatura } \\
\text { ventos }\end{array}$ & $\begin{array}{l}\text { Reduzir a produção de calor, } \\
\text { alcançar a perda de calor pela } \\
\text { evaporação e convecção. }\end{array}$ & $\begin{array}{l}\text { Ampliação da área vegetada, da } \\
\text { permeabilidade do } \\
\text { recobrimento do solo }\end{array}$ \\
\hline $\begin{array}{l}\text { Incrementar o movimento do } \\
\text { ar. }\end{array}$ & $\begin{array}{l}\text { Evitar vegetação arbustiva, } \\
\text { incrementar a idéia de }\end{array}$ \\
\hline Umidade & $\begin{array}{l}\text { Evitar a absorção de umidade } \\
\text { e diminuir a pressão de vapor. }\end{array}$ & $\begin{array}{l}\text { ambiental do conjunto das } \\
\text { praças }\end{array}$ \\
\hline Radiação & $\begin{array}{l}\text { Reduzir a absorção por } \\
\text { radiação. }\end{array}$ & $\begin{array}{l}\text { Reduzir a área de } \\
\text { pavimentação, ampliando áreas }\end{array}$ \\
\hline com recobrimento do solo \\
\hline chuvas & $\begin{array}{l}\text { Máxima proteção nos espaços } \\
\text { públicos }\end{array}$ & $\begin{array}{l}\text { Cobertura retrátil para o } \\
\text { boulevard comercial }\end{array}$ \\
\hline
\end{tabular}


Tabela 17 Aplicação de roteiro de princípios bioclimáticos ao processo de projeto urbano

\section{Princípio bioclimático*}

Vegetação para sombreamento absorção de radiação solar.

Os espaços públicos não devem ser de grandes dimensões, devido à necessidade de árvores próximas e sombreamento.

Os espaços abertos devem prevalecer e ser arborizados, procurando-se a perda de calor pela evaporação e pelo diferencial térmico produzido.

Sombra densa para os caminhos só de pedestres e sombra mais leve para pessoas e veículos

Procurar sombrear áreas de permanência através de elementos como marquises, vegetação, pérgulas, portais ou alargamento de calçadas.

a orientação que oferecer espaços ensolarados e espaços sombreados é a mais favorável, acompanhada de vegetação a oeste.

Superfícies gramadas devem substituir as pavimentadas para reduzir a absorção da radiação solar e a reflexão sobre as áreas construídas

Construções separadas entre si e rodeadas de árvore / permitir circulação do ar entre as edificações.

Favorecer a drenagem para diminuir o alto índice de vapor d'água contido no ar

\section{Solução de projeto}

Preservação das espécies existentes e ampliação de espécies de sombra no verão

Reformulação da área de praça seca (Dom José Marcondes) em duas praças menores circundadas por vegetação e com cobertura modular de pérgula, orientada para o Norte.

Aumento da área permeável criação de ambientes de permanência em áreas vegetadas. Bosque de estar.

Diferentes tipologias de espaços de permanência: praça de acesso, estar do bosque, terraço de estar, etc

Calçada estendida na Voluntários, pérgula na praça do sol

As principais praças (das decíduas e do sol) oferecem sol e sombra e estão voltadas para o norte

Substituição de grande parte da área pavimentada por canteiros e vegetação herbácea e arbórea

Edificações esparsas (micro-comércio), mesmo que agrupados, orientados para ventilação

Boulevard comercial define unidade ao passeio e evita o acúmulo de água ladeada por canteiro pluvial. 


\subsection{PROPOSTA DE INTERVENÇAO BIOCLIMÁTICA}

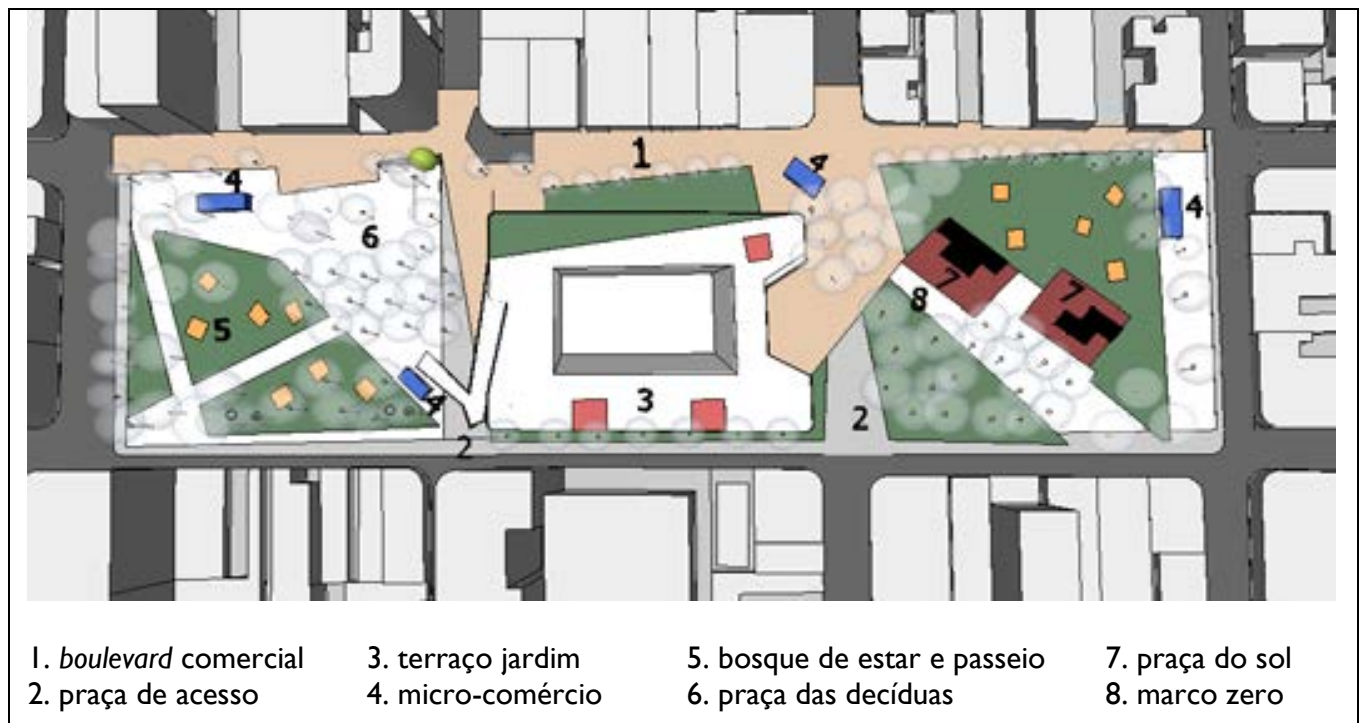

Figura 64 proposta de readequação bioclimática das praças Rui Barbosa e Dom José Marcondes e "calçadão" da Bernardino - implantação
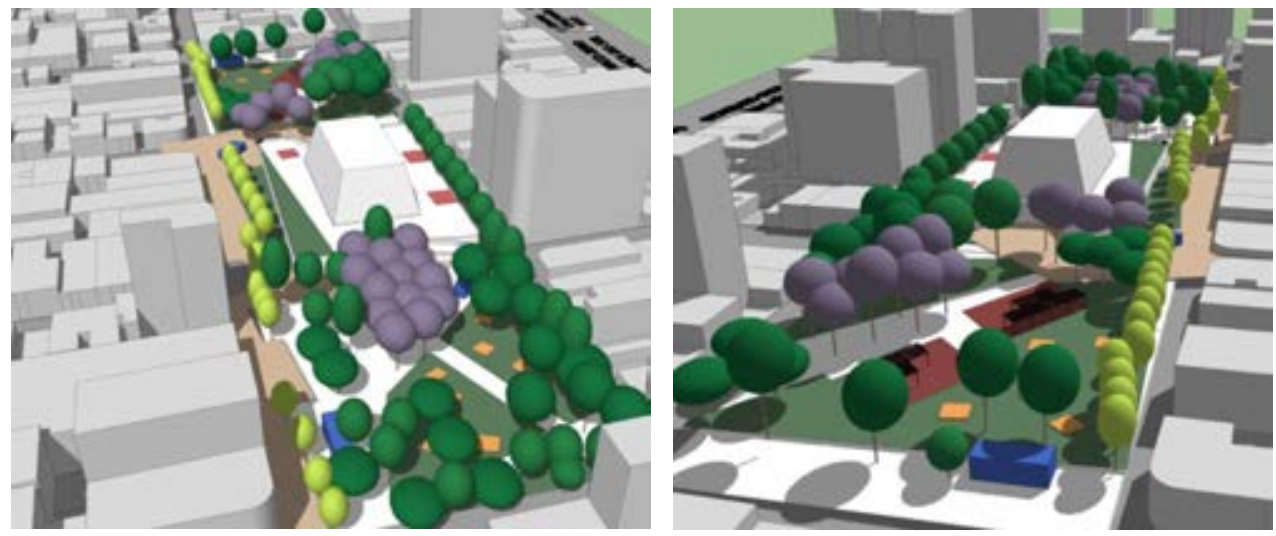

Figura 65 Vista aérea a partir do início da rua Voluntários de São Paulo, mostrando a praça Dom José Marcondes em primeiro plano, Face Nordeste.

Figura 66 Vista aérea a partir do início da rua Bernardino de Campos, mostrando a praça Dom José Marcondes em primeiro plano, Face Norte, para onde estão voltadas as praças do sol. À direita está o boulevard comercial. 


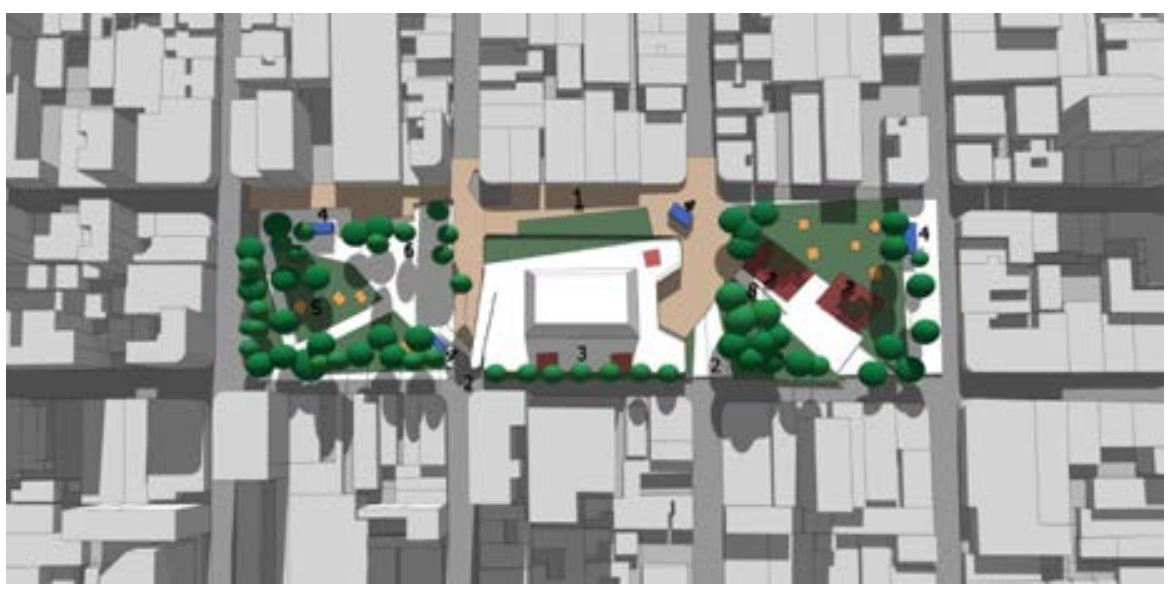

Figura 67 - Vista aérea da praça mostrando mapa de sombras e vegetação no inverno.

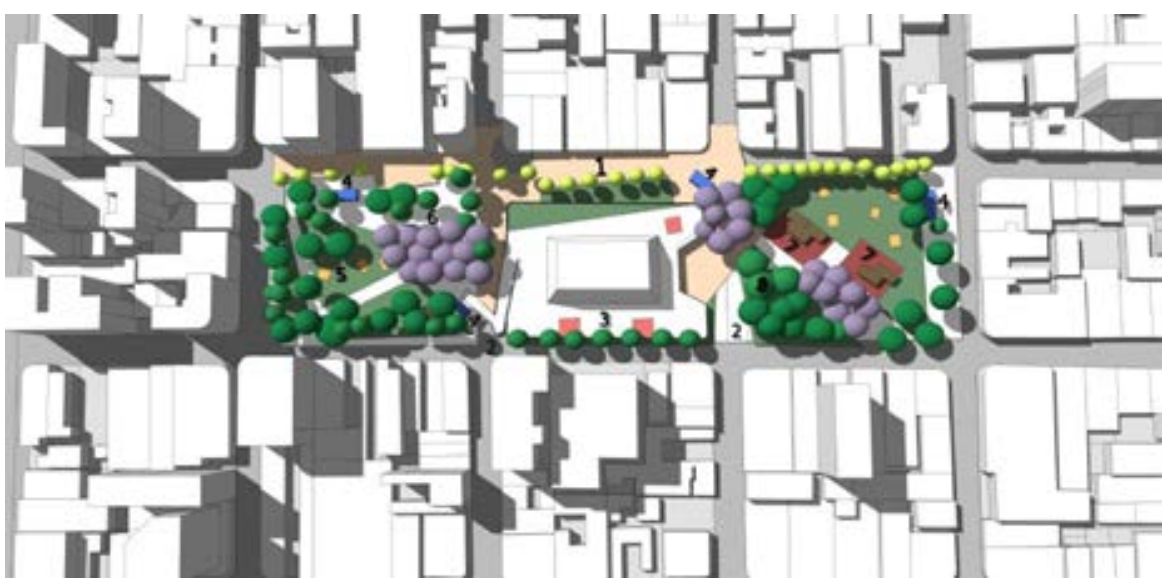

Figura 68 Vista aérea da praça mostrando mapa de sombras e vegetação em dia de verão. 


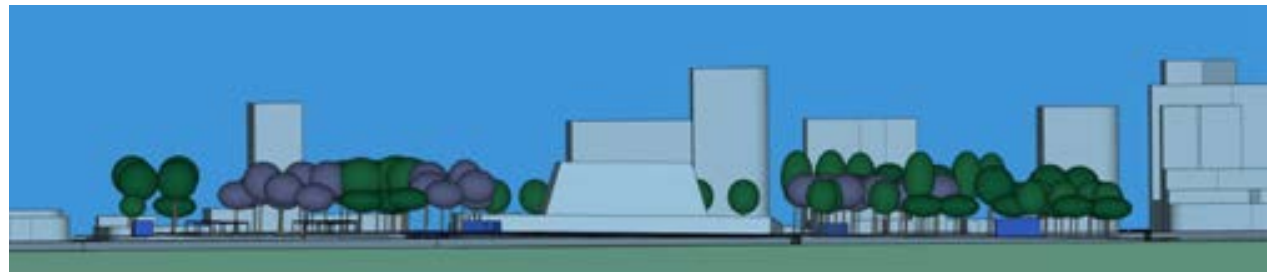

Figura 69 Vista a partir da rua Bernardino de Campos, “calçadão”, orientação Noroeste.

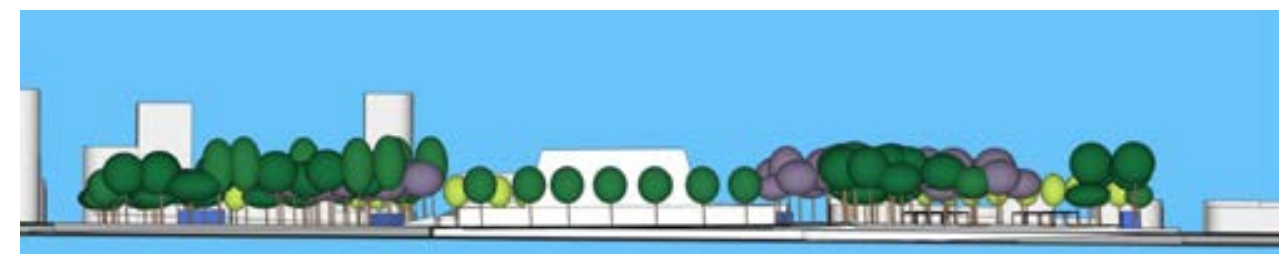

Figura 70 Vista a partir da rua Voluntários de São Paulo, orientação Sudeste.

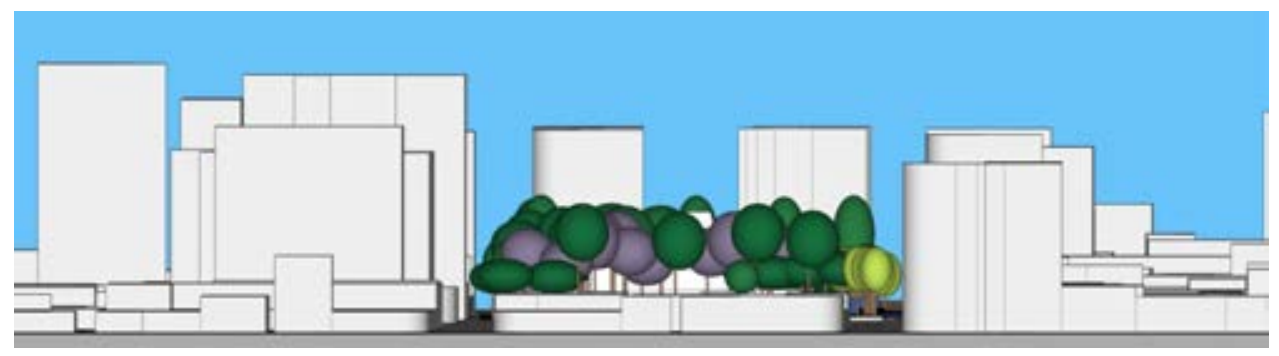

Figura 7I Vista externa a partir da rua Pedro Amaral, Nordeste.

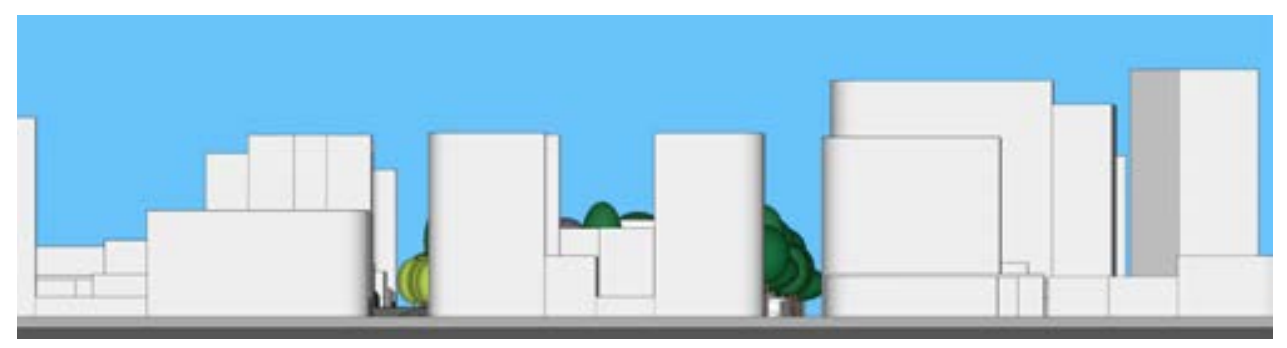


Figura 72 Vista externa a partir da rua Silva Jardim, Sudoeste.

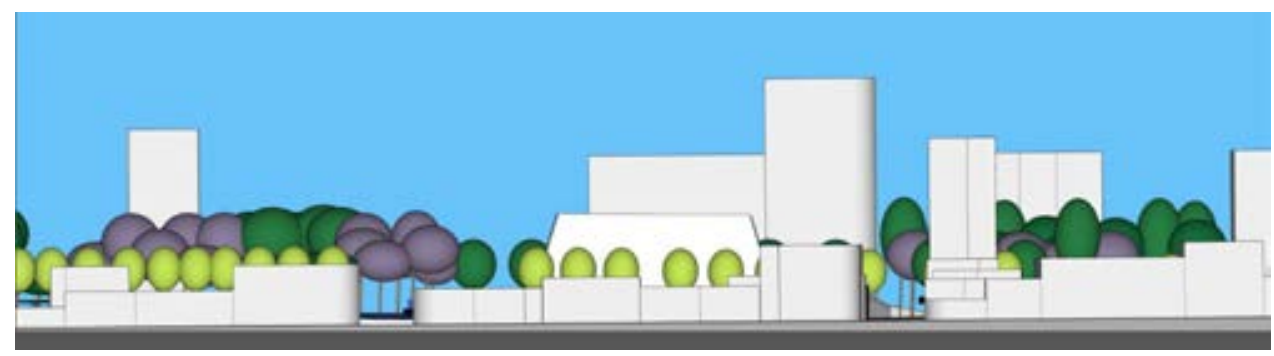

Figura 73 Vista externa a partir da rua General Glicério, Noroeste.

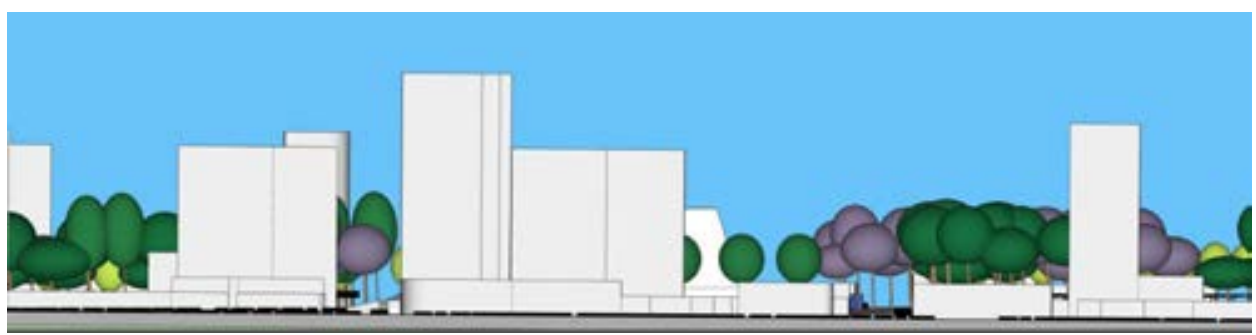

Figura 74 Vista externa a partir da rua XV de Novembro, Sudeste

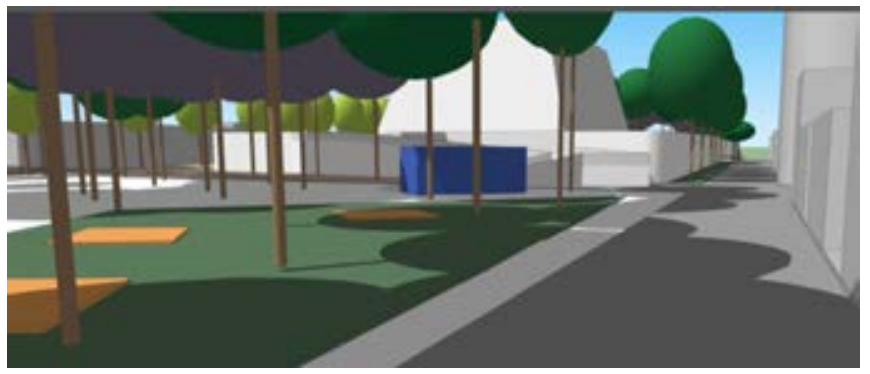

Figura 75 Vista da Praça Rui Barbosa a partir da rua Voluntários de São Paulo. Arborização existente, ampliação de piso vegetal, criação de praça de acesso com equipamento modular de micro-comércio (bloco azul). 


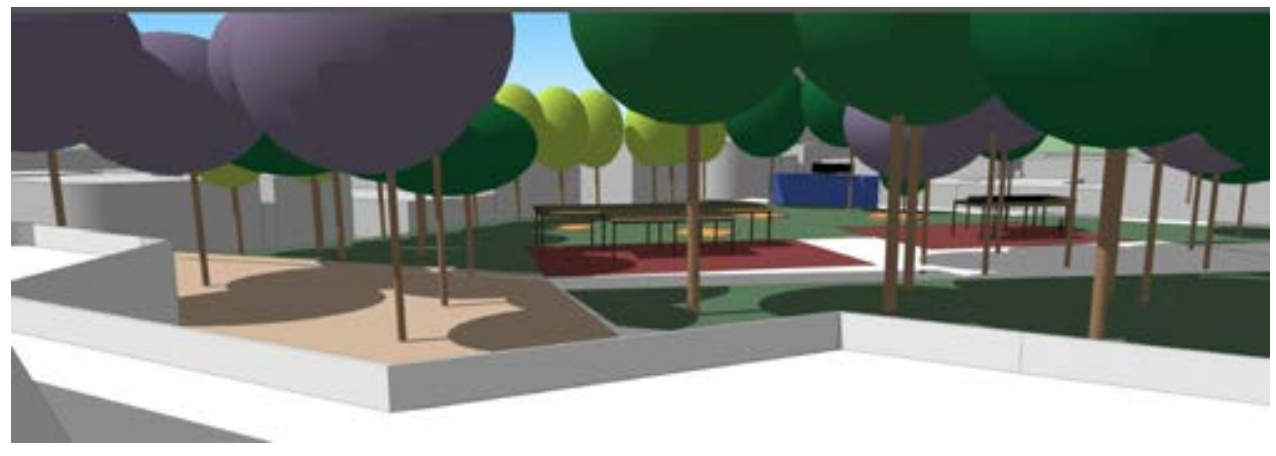

Figura 76 Vista da Praça Dom José Marcondes a partir do terraço-jardim da laje da igreja. Aumento de área permeável e vegetação arbórea e coberturas para proteção solar em madeira laminada colada $(\mathrm{MCL})$ nas praças do sol.
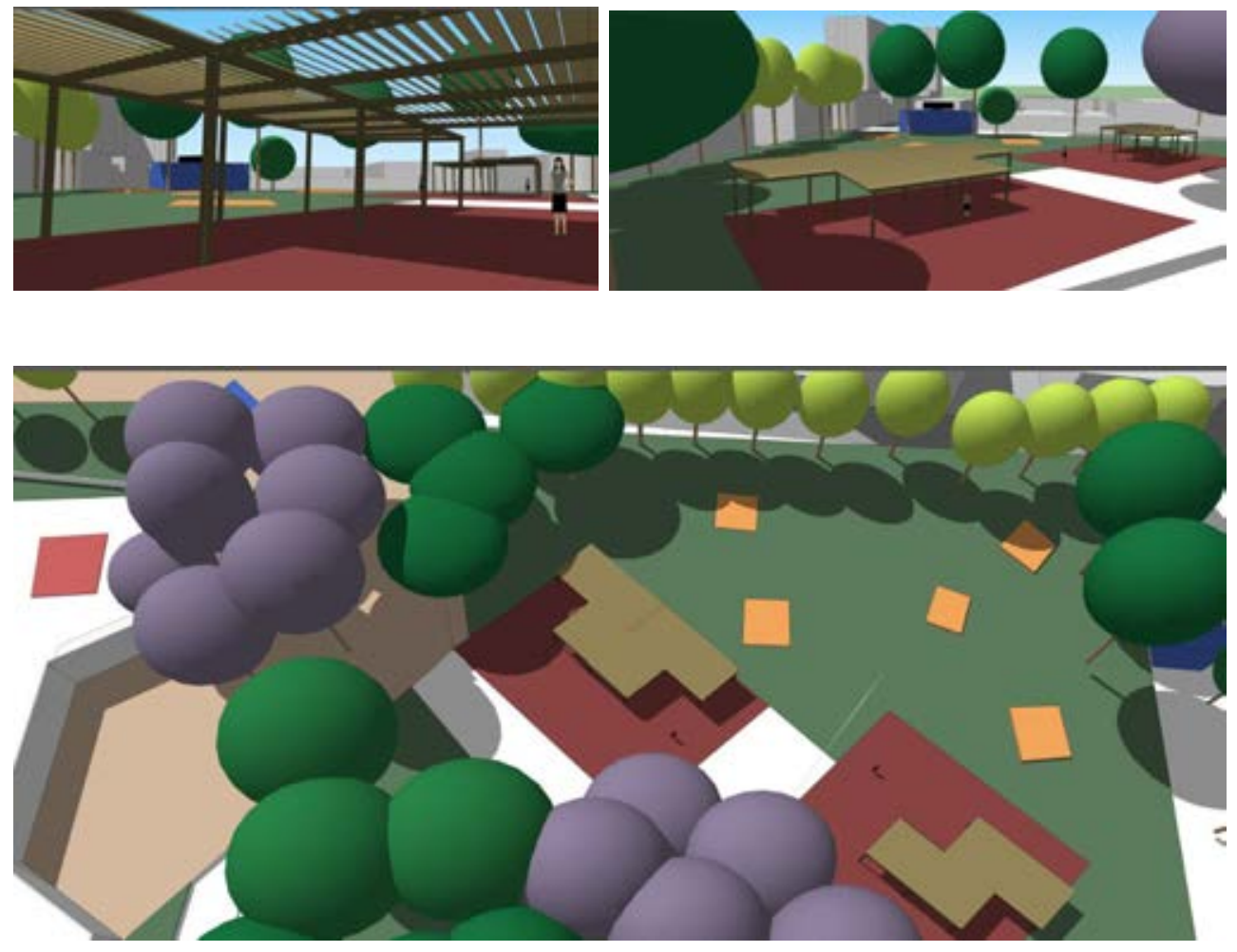


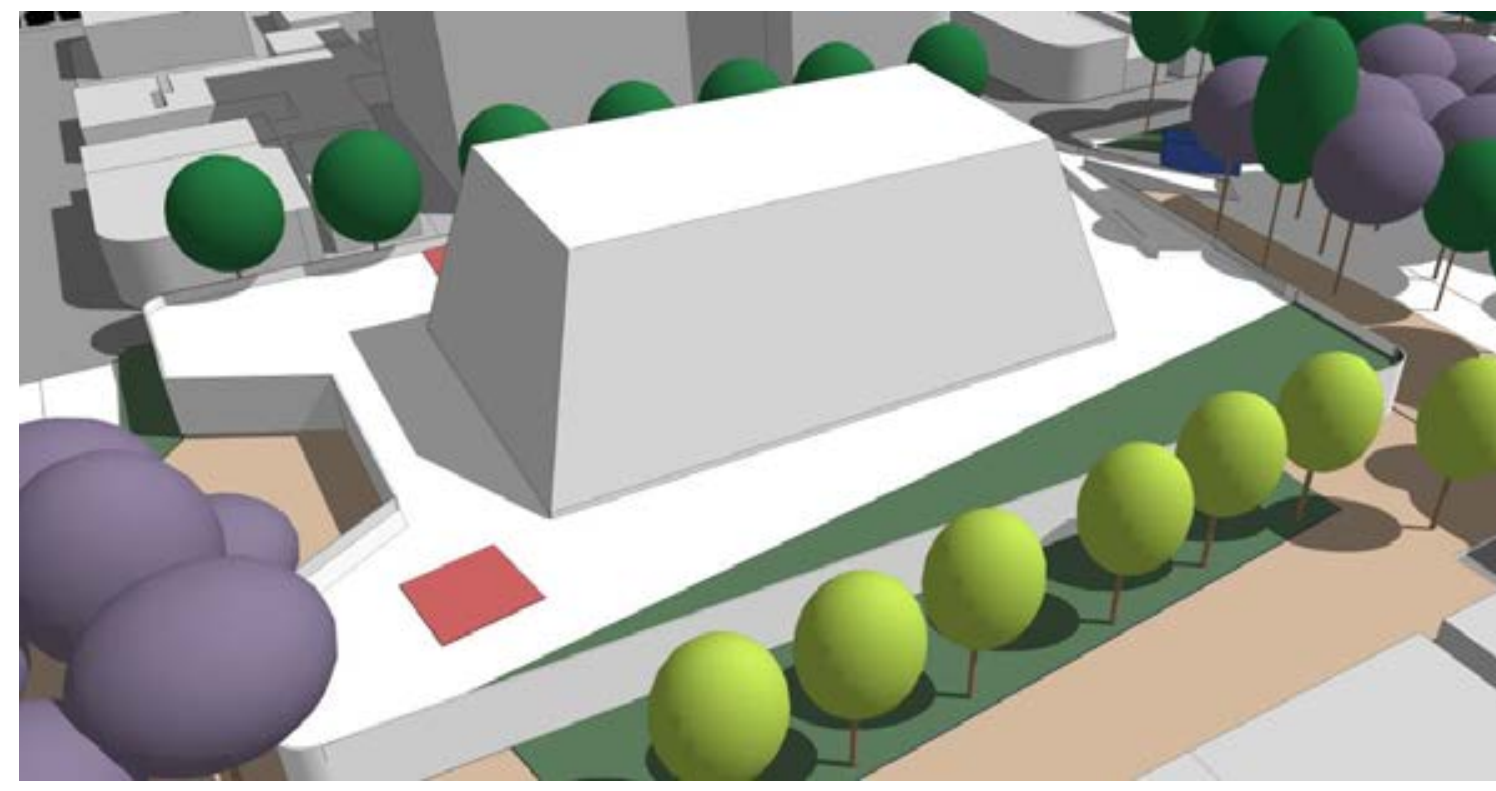

Figura 77 - Vista do terraço jardim e mirante sobre a laje da igreja 


\subsection{CONCLUSÕES}

Este trabalho buscou contribuir para a melhoria da qualidade de espaços livres urbanos. Para isso, foi desenvolvido o procedimento de avaliação bioclimática de uma fração urbana em São José do Rio Preto, o que permitiu verificar que em um mesmo ambiente climático, as diferentes configurações da morfologia urbana modificam o microclima interferindo na qualidade e uso dos espaços livres. Também foi possível identificar o potencial papel dos espaços livres em contribuir com a melhoria do conforto urbano, quando considerados os aspectos climáticos em estudos e decisões de projeto.

Os espaços livres urbanos podem se transformar em verdadeiro oásis no interior das cidades, capazes de atenuar as condições extremas do clima e da poluição do ar. Além disso, podem contribuir para transformar as cidades em lugares adequados às pessoas e, com isso, em ambientes mais seguros e saudáveis.

A análise das condições microclimáticas aliada ao estudo da morfologia urbana, realizados por meio da caracterização da forma urbana, das variáveis ambientais, da investigação do conforto térmico percebido pelo usuário, possibilitaram a elaboração de diretrizes que podem ser aplicadas a projeto urbano no objeto de estudo e locais com condições ambientais similares. Os estudos sobre as demandas de usos, apropriações, fluxos e deslocamentos permitiram a elaboração de uma proposta de projeto de arquitetura de espaços livres exclusivamente para a área de estudo. 


\subsection{Trabalhos futuros}

O desenvolvimento desta pesquisa gerou novas possibilidades de trabalho e ideias para projetos futuros. Os conceitos de arquitetura de espaços livres, bioclimatismo e conforto urbano têm sido muito discutidos no meio acadêmico. Entretanto, os ambientes urbanos reais refletem a distância enorme entre a prática de projeto e o universo científico. Os trabalhos futuros procurariam reduzir este descompasso. Algumas idéias são apresentadas a seguir.

Incorporar os conceitos de APO (Avaliação Pós-Ocupação), ergonomia e percepção ambiental ao processo da pesquisa, possibilitando estreitar ainda mais o entendimento sobre os usos e demandas e a relação da comunidade com o projeto.

Aprofundar as pesquisas para criação de uma metodologia de análise e projeto bioclimático de arquitetura de espaços livres,

Continuar a pesquisa em outros espaços livres da cidade como estudo comparativo entre os resultados obtidos com as análises. 


\section{REFERÊNCIAS}

AKBARI, Hashem; ROSE, L. Shea; TAHA, Haider; Characterizing the Fabric of the Urban Environment: A Case Study of Sacramento, California Heat Island Group Environmental Energy Technologies Division, Lawrence Berkeley National Laboratory University of California; Berkeley, CA 94720; 1999.

ANDRADE, Carlos Roberto; Luís Saia: um certo urbanismo moderno

ASHIHARA, Yoshinobu. El diseño de espacios exteriores. Barcelona: Editoria Gustavo Gilli, 1982.

ASSIS, Eleonora Sad; Aplicações da Climatologia Urbana no Planejamento da Cidade: Revisão dos Estudos Brasileiros, Escola de Arquitetura da Universidade Federal de Minas Gerais.

K. AXARLI I, D. TELI. Implementation of bioclimatic principles in the design of urban open spaces: microclimatic improvement for the cooling period of an open space adjacent to the sea. PLEA 2008 - 25th Conference on Passive and Low Energy Architecture, Dublin: 2008.

BARBIRATO, Gianna Melo; TORRES, Simone Carnaúba, SOUZA, Lea Cristina Lucas de; Clima Urbano e Eficiência Energética nas Edificações; PROCEL EDIFICA, Rio de Janeiro: $201 \mathrm{l}$.

BOSCH, Ulrike; KATZSCHNER, Lutz; RÖTTGEN, Mathias; A methodology for bioclimatic microscale mapping of open spaces; University of Kassel, Kassel, Germany. 2005

BRANDI, Agostinho. São José do Rio Preto I852-I894: Roteiro Histórico do Distrito - Contribuição para o Conhecimento de suas Raízes, São José do Rio Preto: 2002.

BRUSE, Michael; DREY, Christl; KATZSCHNER, Lutz; MAYER, Helmut; Strategies and concepts for thermal comfort discussions in urban planning to mitigate the impacts of climate extremes; Geomatics Group, Geography Department, Ruhr-University Bochum, Germany 
BUSTOS ROMERO, Marta Adriana; Princípios Bioclimáticos para o Desenho Urbano. São Paulo, Proeditores: 1988 I28p.

, M. A. Arquitetura bioclimática do espaço público,

Brasília-DF, Editora Universidade de Brasília, 200I, 226p.

CHATZIDIMITRIOU, Angeliki; CHRISSOMALLIDOU Niobe; YANNAS, Simos; Ground surface materials and microclimates in urban open spaces; PLEA2006 - The 23rd Conference on Passive and Low Energy Architecture, Geneva, Switzerland, 2006.

Cool Pavement Report EPA Cool Pavements Study - Task 5, draft report prepared for Heat Island Reduction Initiative, U.S. Environmental Protection Agency, prepared by Cambridge Systematics, Inc., 2005

CORBELLA, Oscar, YANNAS, Simos; Em busca de uma arquitetura sustentável para os trópicos; Rio de Janeiro: Revan, 2009, 308p.

COSTA, Angelina Dias Leão; Análise bioclimática e investigação do conforto térmico em ambientes externos : uma experiência no bairro de Petrópolis em Natal/RN Natal, RN, 2003. 179 p. Dissertação (Mestrado) Universidade Federal do Rio Grande do Norte. Programa de Pós-Graduação em Arquitetura e Urbanismo.

DUARTE, Denise Helena Silva; SERRA, Geraldo Gomes. Padrões de ocupação do solo e microclimas urbanos na região de clima tropical continental: correlações e proposta de um indicador. Tese de doutorado FAU USP 2000

FROTA, Anésia Barros; SCHIFFER, Sueli Ramos. Manual de conforto térmico: 5. Ed. São Paulo: Studio Nobel, $200 \mathrm{I}$.

GARTLAND, Lisa; Ilhas de Calor: como mitigar zonas de calor em áreas urbanas; São Paulo: Oficina de Textos, 2010.

GIANNOPOULOU, Maria; Bioclimatic Principles and Urban Open Spaces: The Case of Xanthi. World Academy of Science, Engineering and Technology. International Journal of Social, Management, Economics and Business Engineering Vol:6 No:7, 2012 
GONÇALVES J. C. S.; DUARTE, D. H. S.; Arquitetura sustentável: uma integração entre ambiente, projeto e tecnologia em experiências de pesquisa, prática e ensino. Ambiente Construído, Porto Alegre, v. 6, n. 4, p. 5I-8I out./dez. 2006.

IBGE - Instituto Brasileiro de Geografia e Estatística http://www.censo20 10.ibge.gov.br/sinopse/index.php?dados=8

IHGG - Instituto Histórico, Geográfico e Genealógico de São José do Rio Preto/SP http://ihggsjrp.blogspot.com.br/p/album-cotidiano.html

KATZCHNER, Lutz; Urban Climate studies as tools for urban planning and architecture; In: Encontro Nacional de Conforto no Ambiente Construído, 4. ENCAC, Salvador-BA; ANTAC, 1997. ICD-Rom.

LAMAS, José M. R. G. Morfologia urbana e desenho da cidade. Lisboa: Fundação Caluste Gulbenkian, Junta Nacional de Investigação Científica, 1993.

LAMBERTS, R.; GHISI, Enedir; ABREU, Ana Lígia P., CARLO, Joyce C.; Desempenho térmico de edificações; LABEE Laboratório De Eficiência Energética em Edificações Universidade Federal de Santa Catarina; 2005.

LECHNER, N.; Heating, Cooling, Lighting: Design Methods for architects, $2^{\text {nd }}$ Edition, New York: 2000, 620p.

LEI COMPLEMENTAR N²24 DE 06 DE OUTUBRO DE 2006. Dispõe sobre o Plano Diretor de Desenvolvimento Sustentável de São José do Rio Preto

LEI N 5I35 DE 24 DE DEZEMBRO DE 1992. Prefeitura Municipal De São José Do Rio Preto Estado De São Paulo Secretaria Municipal De Planejamento

LODI, Nilce; Praças de ontem e de hoje São José do Rio Preto, 30 de março de $2007 . \quad$ Disponível em: http://www.diarioweb.com.br/noticias/corpo_noticia.asp? IdCategoria=208\& IdNoticia $=$ I | 737 | 
LODI, Nilce; Transformações de uma praça pública. São José do Rio Preto, II de janeiro de 2009. Disponível em: http://www.diarioweb.com.br/noticias/corpo_noticia.asp?ldCategoria=208\& IdNoticia $=\mid$ | 737 |

LOMBARDO, Magda A. ; O clima e a cidade; ENCAC, Salvador: 1997.

LYNCH, Kevin. A imagem da cidade. Tradução de Jefferson Luiz Cavalho. São Paulo: Editora Martins Fontes, 1997.

MACEDO, Sílvio Soares; ROBBA, Fábio. Praças brasileiras. São Paulo: Editora da Universidade de São Paulo, 2002.

MACEDO, Sílvio Soares, Espaços Livres, in Paisagem e Ambiente: ensaios, $n^{\circ} 7$ p. 15-56, São Paulo, 1995.

MACEDO, S.S., Espaços Livres públicos nas cidades brasileiras, in Revista Geográfica de América Central, Número Especia EGAL, 20II

MAGNOLI, M. M.; Espaço Livre, objeto de trabalho, in Paisagem e Ambiente: ensaios, n 21, p 175-198, São Paulo, 2006.

MASCARÓ, L. ; MASCARÓ, J. Vegetação urbana, UFRGS, Porto Alegre, 2002. 242p.

MASCARÓ, L. Ambiência urbana. Porto Alegre, Sagra / DC Luzatto, 1996, 199p.

MORAES, Annamaria de, MONT'ALVÂO, Cláudia, Ergonomia: conceitos e aplicações, Rio de Janeiro, 2AB Editora, 2000.

OKE, T. R. Boundary layer climates. 2.ed. New York: Routledge, 1996, 435p.

ONU (Organização das Nações Unidas) - The State of Latin American and Caribbean Cities 2012. United Nations Human Settlements Programme (UN-Habitat),August, 2012. Disponível em: www.unhabitat.org 
PELLEGRINO, Paulo R. M., CORMIER, Nathaniel S. Infra-estrutura verde: uma estratégia paisagística para a água urbana. Paisagem Ambiente: ensaios - n. 25 - São Paulo - p. 125 - | 42 - 2008

PREFEITURA MUNICIPAL DE SÃO JOSÉ DO RIO PRETO. Secretaria de Planejamento e Gestão Estratégica Municipal. Mapas de São José do Rio Preto. Acesso em: 27 nov. 2013. Disponível em: <http://www.riopreto.sp.gov.br/PortalGOV/do/subportais_Show?c=5050>.

PREFEITURA MUNICIPAL DE SÃO JOSÉ DO RIO PRETO. Secretaria de Planejamento Estratégico, Ciência, Tecnologia e Inovação. Conjuntura Econômica 2012, 2013, 2014 e Conjuntura Ambiental. Disponível em: http://www.riopreto.sp.gov.br/PortalGOV/do/subportais_Show?c=60202

QUAPÀ - Quadro do Paisagismo. Disponível em: http://www.quapa.fau.usp.br/quapa_desenv/SearchMan/busca.php

ROCHA, L. M. V.; SOUZA, L. C. L.; CASTILHO, F. J. V. Ocupação do Solo e Ilha de Calor Noturna em Avenidas Marginais a Um Córrego Urbano. Ambiente Construído, Porto Alegre, v. II, n. 3, p. |6I-175, out./dez. 201 I.

ROGERS, Richard; GUMUCHDJIAN, Philip. Cidades para um pequeno planeta. Barcelona: Gustavo Gili; 200I.

PEZZUTO, Claudia Cotrim; Avaliação do ambiente térmico nos espaços urbanos abertos. Estudo de caso em Campinas, SP; Tese de Doutorado, Campinas, SP: [s.n.], 2007. FEC - UNICAMP

SYNNEFA, A.; SANTAMOURIS, M. and LIVADA, I. A comparative study of the thermal performance of reflective coatings for the urban environment; International Conference "Passive and Low Energy Cooling IOI for the Built Environment”, Santorini, Greece, 2005.

, A.; DANDOU, A.; SANTAMOURIS, M., TOMBROU, M.; On the Use of Cool Materials as a Heat Island Mitigation Strategy; Department of Applied Physics, National and Kapodistrian University of Athens, Athens, Greece, 2008. 
YANNAS, Simos. Adaptive Skins and Microclimates. Plea2004 - The 2 I th Conference on Passive and Low Energy Architecture. Eindhoven, The Netherlands: 2004. 


\section{ANEXOS}

\section{ANEXO I - PLANILHA DE MEDIÇÃO E FORMULÁRIO DE ENTREVISTA}

Avaliação do ambiente térmico de espaços urbanos abertos em São José do Rio Preto Etapa de Pesquisa de Campo Programa de pós-graduação IAU USP

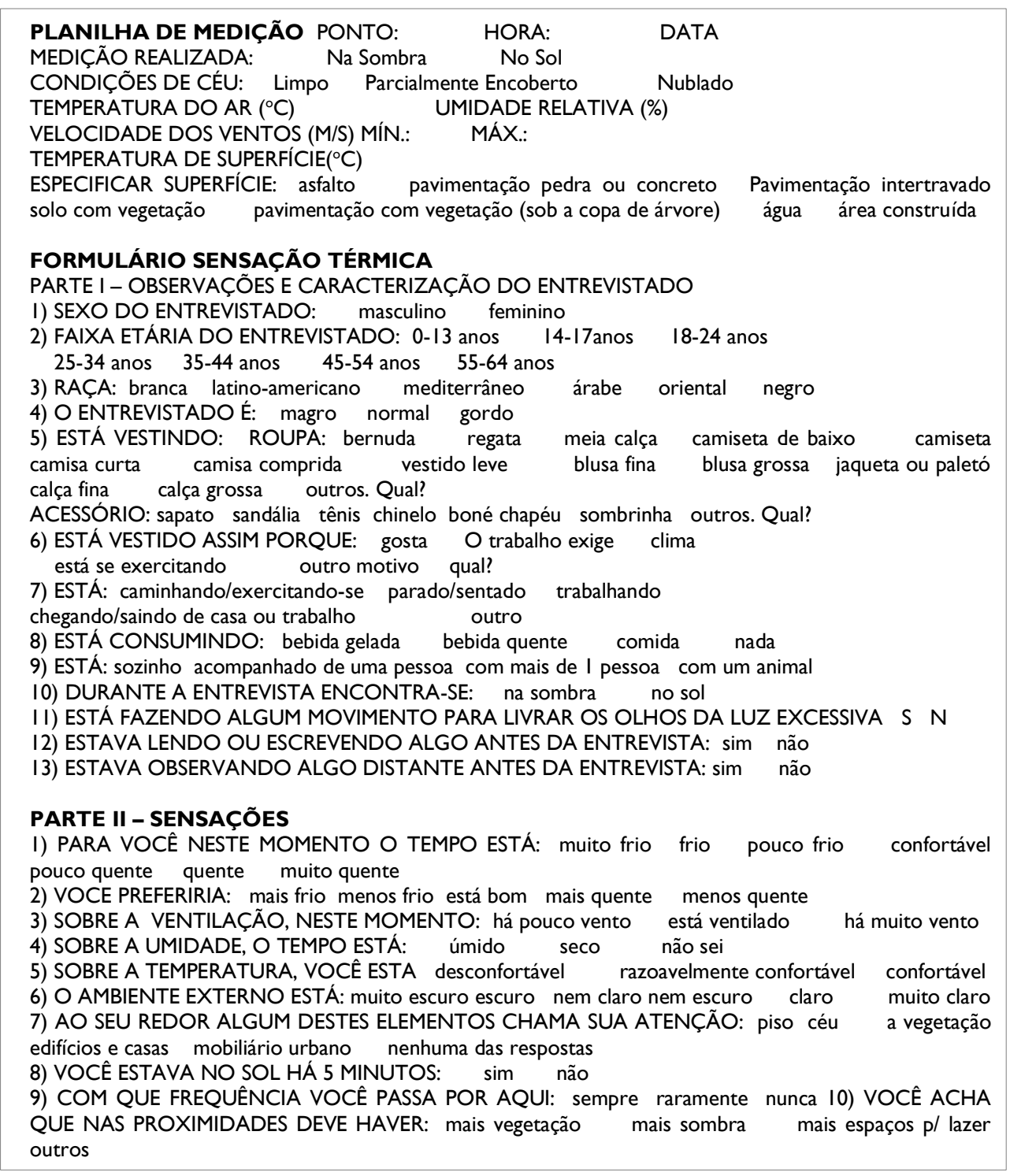


ANEXO 2 - BANCO DE DADOS MICROCLIMÁTICOS

ANEXO 2 A - BANCO DE DADOS

TEMPERATURA E UMIDADE RELATIVA DO AR

\begin{tabular}{|c|c|c|c|c|}
\hline Dia & Ponto & Hora & Temp & Umid \\
\hline 1 & 1 & 8 & 24,01 & 74,2 \\
\hline 1 & 1 & 10 & 26,73 & 66,6 \\
\hline 1 & 1 & 12 & 29,5 & 54,6 \\
\hline 1 & 1 & 14 & 28,31 & 52,6 \\
\hline 1 & 1 & 16 & 27,52 & 63,6 \\
\hline 1 & 2 & 8 & 24,4 & 73,3 \\
\hline 1 & 2 & 10 & 33,59 & 41,3 \\
\hline 1 & 2 & 12 & 36,57 & 33 \\
\hline 1 & 2 & 14 & 31,93 & 38,9 \\
\hline 1 & 2 & 16 & 27,52 & 59,9 \\
\hline 1 & 3 & 8 & 24,79 & 76,9 \\
\hline 1 & 3 & 10 & 28,7 & 60,3 \\
\hline 1 & 3 & 12 & 33,17 & 41,6 \\
\hline 1 & 3 & 14 & 32,76 & 39,1 \\
\hline 1 & 3 & 16 & 27,52 & 63,2 \\
\hline 2 & 1 & 8 & 22,09 & 66,4 \\
\hline 2 & 1 & 10 & 22,86 & 67,7 \\
\hline 2 & 1 & 12 & 25,56 & 60,6 \\
\hline 2 & 1 & 14 & 25,17 & 62,5 \\
\hline 2 & 1 & 16 & 26,34 & 58,8 \\
\hline 2 & 2 & 8 & 22,48 & 65,4 \\
\hline 2 & 2 & 10 & 25,17 & 58 \\
\hline 2 & 2 & 12 & 31,52 & 39,9 \\
\hline 2 & 2 & 14 & 27,52 & 54,6 \\
\hline 2 & 2 & 16 & 28,31 & 49,6 \\
\hline 2 & 3 & 8 & 22,09 & 68,4 \\
\hline 2 & 3 & 10 & 23,63 & 65,2 \\
\hline 2 & 3 & 12 & 29,1 & 48,5 \\
\hline 2 & 3 & 14 & 26,73 & 57,3 \\
\hline 2 & 3 & 16 & 27,52 & 54,6 \\
\hline
\end{tabular}


ANEXO 2.B - BANCO DE DADOS

VELOCIDADE DOS VENTOS

\begin{tabular}{|c|c|c|c|c|c|}
\hline Dia & Ponto & Hora & Vel Max & Vel Min & Vel Méd \\
\hline 1 & 1 & 8 & 1,4 & 0,1 & 0,75 \\
\hline 1 & 1 & 10 & 0,8 & 0,4 & 0,6 \\
\hline 1 & 1 & 12 & 0,8 & 0,3 & 0,55 \\
\hline 1 & 1 & 14 & 0,6 & 0,1 & 0,35 \\
\hline 1 & 1 & 16 & 1,8 & 0.3 & 1,8 \\
\hline 1 & 2 & 8 & 2 & 1 & 1,5 \\
\hline 1 & 2 & 10 & 1,7 & 0,9 & 1,3 \\
\hline 1 & 2 & 12 & 1,1 & 0.1 & 1,1 \\
\hline 1 & 2 & 14 & 1,5 & 0,1 & 0,8 \\
\hline 1 & 2 & 16 & 1,3 & 0,8 & 1,05 \\
\hline 1 & 3 & 8 & 0,7 & 0 & 0,35 \\
\hline 1 & 3 & 10 & 0,9 & 0,1 & 0,5 \\
\hline 1 & 3 & 12 & 1,3 & 0,1 & 0,7 \\
\hline 1 & 3 & 14 & 0,9 & 0,3 & 0,6 \\
\hline 1 & 3 & 16 & 1,3 & 0,3 & 0,8 \\
\hline 2 & 1 & 8 & 3,4 & 0,6 & 2 \\
\hline 2 & 1 & 10 & 1,5 & 0,3 & 0,9 \\
\hline 2 & 1 & 12 & 1,2 & 0,1 & 0,65 \\
\hline 2 & 1 & 14 & 2,3 & 0,7 & 1,5 \\
\hline 2 & 1 & 16 & 2,1 & 0,4 & 1,25 \\
\hline 2 & 2 & 8 & 2 & 0,2 & 1,1 \\
\hline 2 & 2 & 10 & 1,3 & 0 & 0,65 \\
\hline 2 & 2 & 12 & 1,6 & 0.4 & 1,6 \\
\hline 2 & 2 & 14 & 2,5 & 0,9 & 1,7 \\
\hline 2 & 2 & 16 & 2 & 0,1 & 1,05 \\
\hline 2 & 3 & 8 & 2,4 & 0,1 & 1,25 \\
\hline 2 & 3 & 10 & 1,2 & 0,1 & 0,65 \\
\hline 2 & 3 & 12 & 1,4 & 0,1 & 0,75 \\
\hline 2 & 3 & 14 & 1,4 & 0,3 & 0,85 \\
\hline 2 & 3 & 16 & 1,4 & 0,2 & 0,8 \\
\hline
\end{tabular}




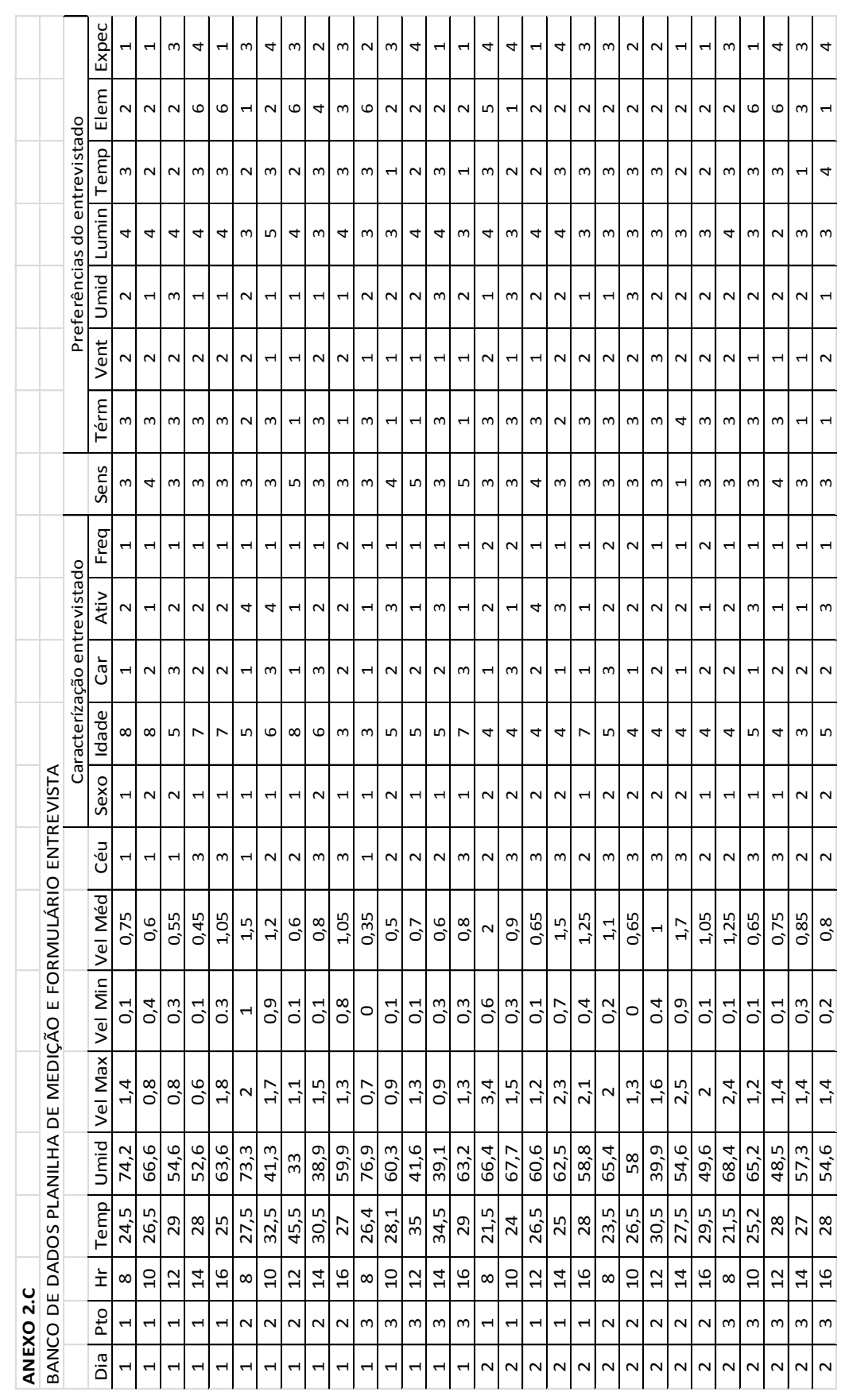


ANEXO 2.D

BANCO DE DADOS DE TEMPERATURA DAS SUPERFÍCIES

\begin{tabular}{|c|c|c|c|c|c|c|c|c|c|c|c|c|c|c|c|}
\hline \multicolumn{16}{|c|}{ BANCO DE DADOS DE TEMPERATURA DAS SUPERFICIES } \\
\hline : & 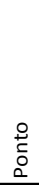 & 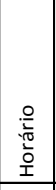 & 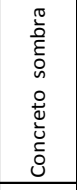 & 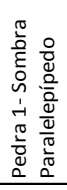 & 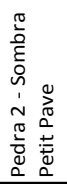 & 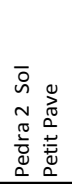 & $\begin{array}{l}3 \\
z \\
\text { o } \\
0 \\
\text { i }\end{array}$ & 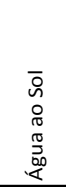 & 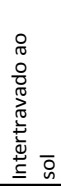 & 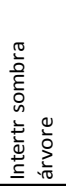 & 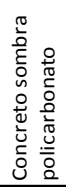 & 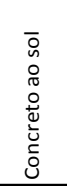 & $\begin{array}{l}\overline{0} \\
0 \\
0 \\
0 \\
\tilde{\sigma} \\
\tilde{5} \\
0 \\
\end{array}$ & 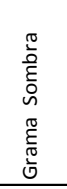 & $\frac{\frac{0}{0}}{\frac{50}{4}}$ \\
\hline 1 & 1 & 8 & 25,8 & 25,4 & 25,6 & & 24,4 & 25,4 & & & & & & & \\
\hline 1 & 1 & 10 & 28,4 & 26,8 & 27,8 & & 25,2 & 26,2 & & & & & & & \\
\hline 1 & 1 & 12 & 29,2 & 28,2 & 36,6 & & 26,2 & 28,2 & & & & & & & \\
\hline 1 & 1 & 14 & 31,6 & 27,2 & 32,2 & & 25,2 & 29,2 & & & & & & & \\
\hline 1 & 1 & 16 & 32,4 & 27,2 & 29,6 & & 25,4 & 28,8 & & & & & & & \\
\hline 1 & 2 & 8 & & & & & & & 34,6 & 26,4 & 31 & 38,8 & & 25,4 & 39,8 \\
\hline 1 & 2 & 10 & & & & & & & 41 & 31,4 & 33,8 & 44 & & 28,6 & 42,1 \\
\hline 1 & 2 & 12 & & & & & & & 50,2 & 33,2 & 37,6 & 51,65 & & 30,4 & 54,3 \\
\hline 1 & 2 & 14 & & & & & & & 42 & 31,2 & 33,4 & 42,6 & & 28,2 & 50,7 \\
\hline 1 & 2 & 16 & & & & & & & 34,8 & 29,8 & 31,6 & 37 & & 25,8 & 48 \\
\hline 1 & 3 & 8 & 26,6 & 33,2 & 26,6 & 27,4 & 25,4 & & & & & 37,2 & & & \\
\hline 1 & 3 & 10 & 28,6 & 38,2 & 28,6 & 31,2 & 26,6 & & & & & 43,4 & & & \\
\hline 1 & 3 & 12 & 31,6 & 45,8 & 31,6 & 38,8 & 28,4 & & & & & 48,4 & & & \\
\hline 1 & 3 & 14 & 29 & 37,6 & 29 & 36,6 & 26,6 & & & & & 41,2 & & & \\
\hline 1 & 3 & 16 & 27,8 & 33,2 & 27,8 & 30,8 & 26 & & & & & 34,6 & & & \\
\hline 2 & 1 & 8 & 23,2 & 23,2 & 24 & & 20,6 & 23,2 & & & & & & & \\
\hline 2 & 1 & 10 & 25,4 & 24,2 & 25,8 & & 22 & 24,2 & & & & & & & \\
\hline 2 & 1 & 12 & 26,4 & 25,8 & 31,4 & & 23,6 & 25,8 & & & & & & & \\
\hline 2 & 1 & 14 & 27,4 & 26 & 28,8 & & 24 & 26,2 & & & & & & & \\
\hline 2 & 1 & 16 & 25,2 & 26,2 & 29,2 & & 23,4 & 25,8 & & & & & & & \\
\hline 2 & 2 & 8 & & & & & & & 26,8 & 24,6 & 26,2 & 26,6 & 23,8 & 21,6 & 29,8 \\
\hline 2 & 2 & 10 & & & & & & & 29,8 & 26 & 27,8 & 30,2 & 25,8 & 25,6 & 33,6 \\
\hline 2 & 2 & 12 & & & & & & & 37,8 & 29,2 & 29,6 & 38,4 & 28,8 & 25,6 & 45,8 \\
\hline 2 & 2 & 14 & & & & & & & 35,8 & 30,2 & 30,8 & 34,6 & 28,4 & 26,6 & 41,4 \\
\hline 2 & 2 & 16 & & & & & & & 34,4 & 30,8 & 28,2 & 36,2 & 27,6 & 27 & 39,2 \\
\hline 2 & 3 & 8 & 24,4 & 25,4 & 23,8 & 24,4 & 22 & & & & & 26,8 & & & \\
\hline 2 & 3 & 10 & 26,8 & 27,4 & 26 & 26,4 & 22,8 & & & & & 28,6 & & & \\
\hline 2 & 3 & 12 & 33,2 & 33,8 & 27,2 & 31,2 & 24,4 & & & & & 35,4 & & & \\
\hline 2 & 3 & 14 & 31,4 & 34,4 & 27,8 & 30,6 & 25 & & & & & 34,4 & & & \\
\hline 2 & 3 & 16 & 28,2 & 30,8 & 27,6 & 29,4 & 25 & & & & & 32,4 & & & \\
\hline
\end{tabular}




\section{ANEXO 3 - CROQUIS DE DESENVOLVIMENTO DO PROJETO}
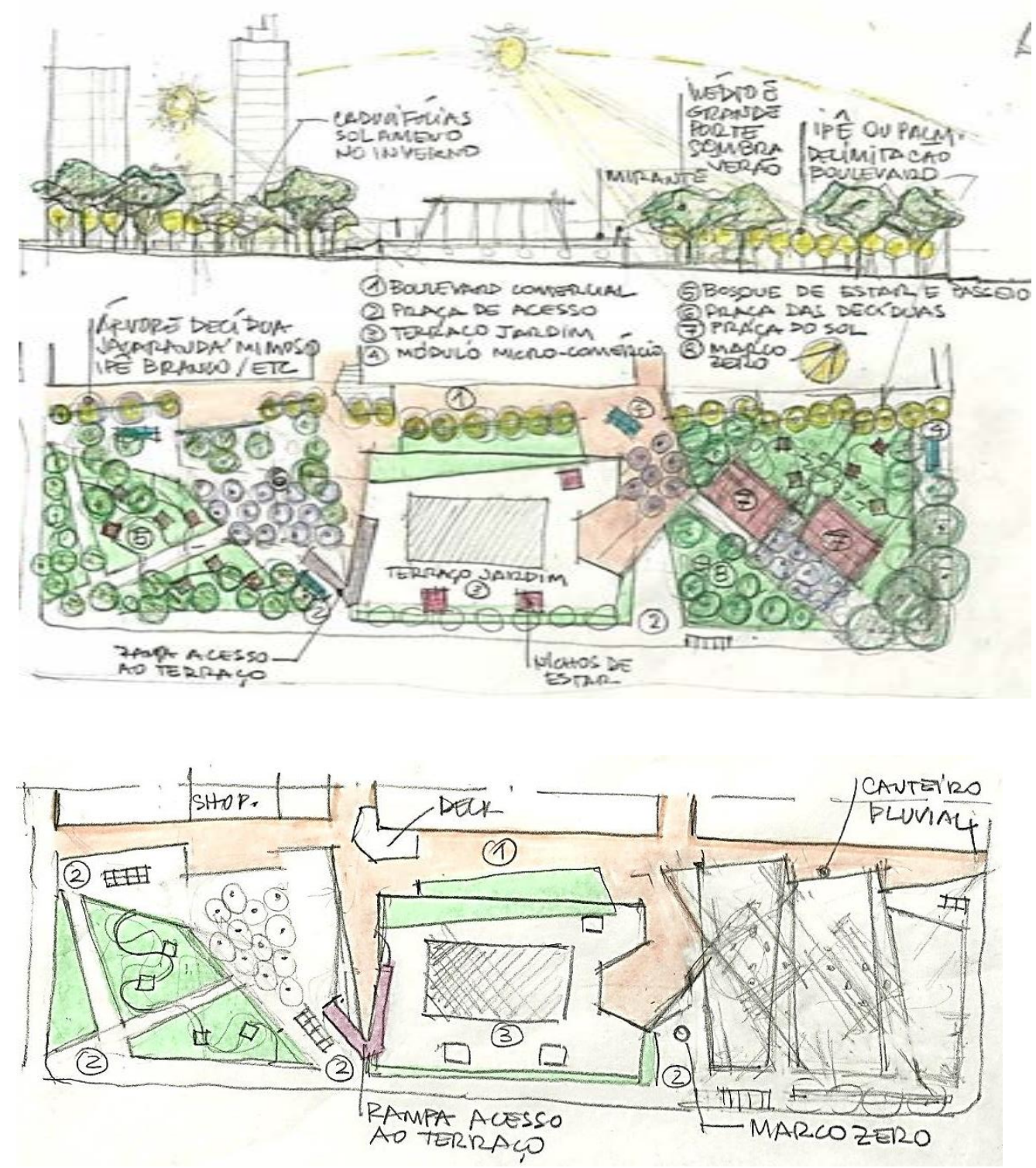


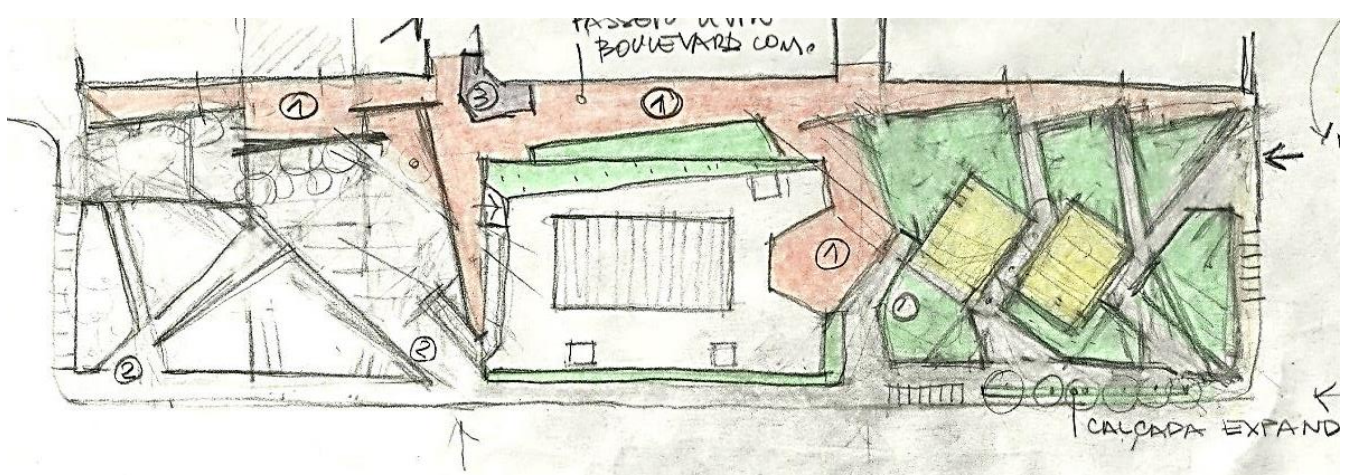

PRÉ-ZONEAMENTO

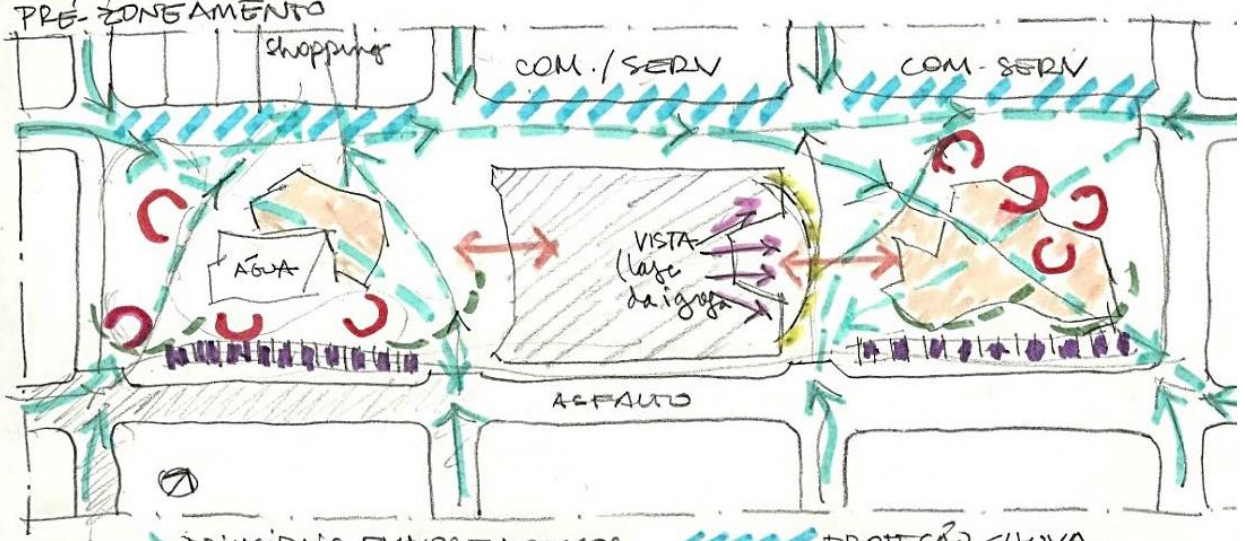

$\Rightarrow$ PRINCIPAIS FLIXOS EACESSOS PROTECRO CHUVA

- barreira quido/som e ar $\Rightarrow$ conexád? integrar espagc C nichos de. testar/cubareas $D$ preservar areas de sol inverno (Gráfico sompla 


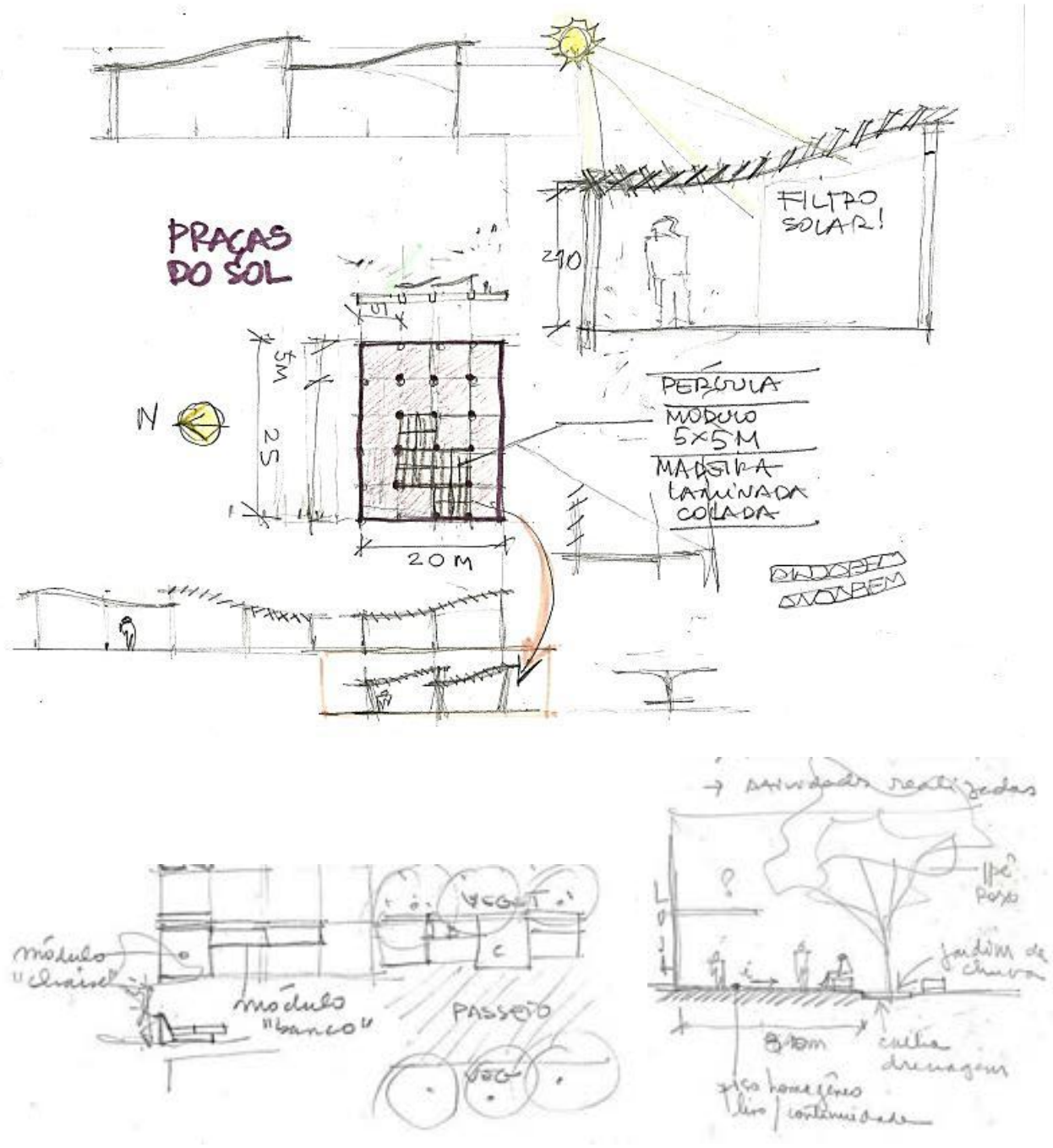

